MARIANA ALBA ZAMPOL

\title{
EFEITO DE ANTIOXIDANTES NATURAIS EM MODELOS PARKINSONIANOS
}

DE SACCHAROMYCES CEREVISIAE

Dissertação apresentada ao Programa de Pós-Graduação em Microbiologia do Instituto de Ciências Biomédicas da Universidade de São Paulo, para obtenção do Título de Mestre em Ciências. 
MARIANA ALBA ZAMPOL

EFEITO DE ANTIOXIDANTES NATURAIS EM MODELOS PARKINSONIANOS DE SACCHAROMYCES CEREVISIAE

Dissertação apresentada ao Programa de Pós-Graduação em Microbiologia do Instituto de Ciências Biomédicas da Universidade de São Paulo, para obtenção do Título de Mestre em Ciências.

Área de concentração: Microbiologia

Orientador: Dr. Mario Henrique de Barros

Versão corrigida. A versão original eletrônica encontra-se disponível tanto na Biblioteca do ICB quanto na Biblioteca Digital de Teses e Dissertações da USP (BDTD). 
DADOS DE CATALOGAÇÃO NA PUBLICAÇÃO (CIP)

Serviço de Biblioteca e Informação Biomédica do

Instituto de Ciências Biomédicas da Universidade de São Paulo

reprodução não autorizada pelo autor

\section{Zampol, Mariana Alba}

Efeito de antioxidantes naturais em modelos parkinsonianos de Saccharomyces cerevisiae / Mariana Alba Zampol. -- São Paulo, 2013.

Orientador: Prof. Dr. Mario Henrique de Barros.

Dissertação (Mestrado) - Universidade de São Paulo. Instituto de Ciências Biomédicas. Departamento de Microbiologia. Área de concentração: Microbiologia. Linha de pesquisa: Biogênese mitocondrial e viabilidade celular.

Versão do título para o inglês: Natural antioxidants action in a Saccharomyces cerevisiae parkinsonian model.

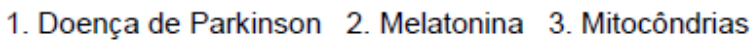

4. Saccharomyces cerevisiae I. Barros, Prof. Dr. Mario Henrique de

II. Universidade de São Paulo. Instituto de Ciências Biomédicas.

Programa de Pós-Graduação em Microbiologia III. Título. 
UNIVERSIDADE DE SÃO PAULO

INSTITUTO DE CIÊNCIAS BIOMÉDICAS

Candidato(a):

Título da Dissertação:

Orientador(a):
Mariana Alba Zampol.

Efeito de antioxidantes naturais em modelos parkinsonianos de Saccharomyces cerevisiae.

Prof. Dr. Mario Henrique de Barros.

\section{A Comissão Julgadora dos trabalhos de Defesa da Dissertação de Mestrado, em sessão pública realizada a considerou
( ) Aprovado(a) \\ ( ) Reprovado(a)}
Examinador(a): Assinatura:
Nome:
Instituição:
Examinador(a): Assinatura:
Nome:
Instituição:
Presidente: Assinatura:
Nome:
Instituição:




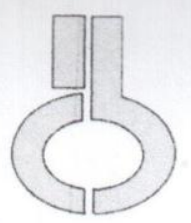

\section{CERTIFICADO DE ISENÇÃO}

Certificamos que o Protocolo CEP-ICB N ${ }^{\circ} 455 / 11$ referente ao projeto intitulado: "Efeito de antioxidantes naturais em modelos parkinsonianos de Saccharomyces cerevisiae" sob a responsabilidade de Mariana Alba Zampol, foi analisado na presente data pela CEUA - COMISSÃO DE ÉTICA NO USO DE ANIMAIS e pela CEPSH- COMISSÃO DE ÉTICA EM PESQUISA COM SERES HUMANOS, tendo sido deliberado que o referido projeto não utilizará animais que estejam sob a égide da lei 11.794 de 8 de outubro de 2008, nem envolverá procedimentos regulados pela Resolução CONEP n¹96 de 1996.

São Paulo, 19 de abril de 2011.

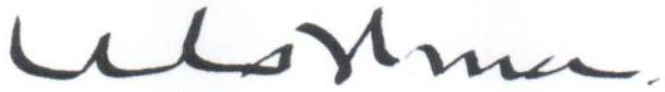

Prof. DR. WOTHAN TAVARES DE LIMA Coordenador da CEUA - ICB/USP

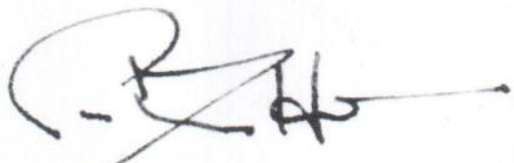

PROF. DR. PAOLO M.A ZANOTTO Coordenador da CEPsh - ICB/USP

$$
\begin{aligned}
& \text { EXPEDIGAO } \\
& \text { DATA .29....10.4.1.1! } \\
& \text { REL. N. . I...5.6.8 }
\end{aligned}
$$




\section{AGRADECIMENTOS}

À minha família, que sempre me apoiou nos momentos mais felizes e nos mais difíceis.

Aos meus amigos, que sempre colocaram um sorriso no meu rosto.

Ao meu orientador, prof. Dr. Mario Henrique de Barros, que sempre teve paciência em me mostrar o caminho.

À Fundação de Amparo à Pesquisa do Estado de São Paulo (FAPESP), ao Conselho Nacional de Desenvolvimento Científico e Tecnológico (CNPq) e à Coordenação de Aperfeiçoamento de Pessoal de Nível Superior (CAPES) pelo suporte financeiro.

Aos amigos do laboratório de Biogênese Mitocondrial e do Instituto de Ciências Biomédicas, que tornaram essa jornada mais prazerosa. 
"An approximate answer to the right question is worth a great deal more than a precise answer to the wrong question."

John Tukey (1915-2000) on priorities in problem solving 


\section{RESUMO}

ZAMPOL, M. A. Efeito de antioxidantes naturais em modelos parkinsonianos de Saccharomyces cerevisiae. 2013. 93 f. Dissertação (Mestrado em Microbiologia) - Instituto de Ciências Biomédicas, Universidade de São Paulo, São Paulo, 2013.

A doença de Parkinson (PD) é uma doença neurodegenerativa que progride com a morte dos neurônios produtores de dopamina, concentrados na substância negra. $\mathrm{O}$ aparecimento da doença está, frequentemente, ligado a mutações ou alterações na expressão do gene $S N C A$, o qual codifica a proteína $\alpha$-sinucleína, cuja função, apesar de não totalmente compreendida, está relacionada com a liberação de neurotransmissores, como a dopamina. A expressão de SNCA em organismos modelos, como a levedura Saccharomyces cerevisiae, produz fenótipos típicos de células parkinsonianas, como a formação de agregados proteicos (corpos de Lewy), que levam a um aumento na produção de espécies reativas de oxigênio (ROS) na mitocôndria. Dessa forma, uma alternativa para seu tratamento poderia ser a neutralização de ROS por antioxidantes naturais, como, por exemplo, a melatonina, hormônio circadiano produzido pela pineal de vertebrados. A melatonina, produzida a partir do triptofano, tem sua via biossintética parcialmente conservada entre humanos e $S$. cerevisiae. Entretanto, falta à levedura a última enzima da via (HIOMT), que converte n-acetil-serotonina em melatonina. Propusemos que a expressão dessa via, incluindo o gene humano que codifica a enzima HIOMT, levaria à produção de melatonina em $S$. cerevisiae, como um possível tratamento das leveduras expressando o gene $S N C A$. Aqui, mostramos que a produção de $\alpha$-sinucleína é prejudicial ao crescimento de $S$. cerevisiae, e causa maior sensibilidade à atividade respiratória, com um fenótipo semelhante a um desafio com o agente oxidante menadiona, sendo um bom modelo para Parkinson. Mostramos, também, que a expressão dos genes da via biossintética da melatonina possui um efeito protetor contra os agentes oxidantes peróxido de hidrogênio e menadiona, conferindo, inclusive, vantagem em meio seletivo para atividade respiratória. Finalmente, apontamos para um efeito benéfico da terapia com melatonina exógena quando células selvagens e parkinsonianas são submetidas a desafios com menadiona. Esse benefício mostrou-se significativamente relevante inclusive para parâmetros de atividade respiratória de mitocôndrias extraídas de leveduras cultivadas na presença do agente antioxidante. Nossos resultados apontam para um papel promissor da melatonina na proteção das células contra danos oxidativos, o que será investigado em relação à proteção contra a presença de $\alpha$-sinucleína em leveduras.

Palavras-chave: Doença de Parkinson. Melatonina. Mitocôndrias. Saccharomyces cerevisiae. 


\begin{abstract}
ZAMPOL, M. A. Natural antioxidants action in a Saccharomyces cerevisiae parkinsonian model. 2013. 93 f. Masters Thesis (Microbiology) - Instituto de Ciências Biomédicas, Universidade de São Paulo, São Paulo, 2013.

Parkinson's disease (PD) is a progressive neurodegenerative disorder dependent on environmental and genetic components, which advances through death of dopaminergic neurons, mostly located in substantia nigra. In most cases, its arising is linked to mutation or expression alteration of the SNCA gene that encodes the $\alpha$-synuclein $(\alpha$-syn) protein, related to neurotransmitter release, like dopamine. One of the hallmarks of this neuropathy is the $\alpha$ syn aggregate deposition (Lewy bodies) that leads to an increase of mitochondrial reactive oxygen species (ROS) production. Hence, a possible alternative treatment for this disease would be ROS neutralization through natural antioxidants, such as melatonin, a hormone synthesized from tryptophan in the vertebrate pineal gland. The human melatonin, biosynthetic pathway is partially conserved in the yeast Saccharomyces cerevisiae, an useful model organism for biochemical and cellular biological studies. However, yeasts lack the latter melatonin biosynthetic enzyme (HIOMT), which converts n-acetyl-serotonin in melatonin. In the present work we propose that the expression of this pathway, including the human gene encoding the HIOMT enzyme, could lead to melatonin production in yeast, as a possible treatment for yeast parkinsonian cells, containing and expressing the SNCA gene. Here we show that $\alpha$-syn production is detrimental to yeast growth and increases its sensibility to respiratory selection. Since this phenotype is similar to the one observed during oxidative challenge of parental cells with menadione, the SNCA expression could be a reliable model for studying Parkinson in yeast. We also show that melatonin biosynthetic pathway expression confers an antioxidant protection against oxidative agents as hydrogen peroxide and menadione, increasing yeast growth in respiratory medium. Finally, we found evidence that melatonin pharmacological therapy is beneficial to parental and parkinsonian cells submitted to menadione challenges. This benefit is significant even to respiratory parameters when mitochondria were extracted from cells grown with melatonin. Our studies point out to a promising role of melatonin in protecting cells against $\alpha$-syn and other species oxidative damage.
\end{abstract}

Keywords: Melatonin. Mitochondria. Parkinson's disease. Saccharomyces cerevisiae. 


\section{LISTA DE FIGURAS}

Figura 1.1 - A substância negra é um dos gânglios basais mesencefálicos

Figura 1.2 - Fotomicrografia do mesencéfalo de macaco com imunocoloração para a enzima tirosina hidroxilase

Figura 1.3 - A interação de $\alpha$-sinucleína com lipídios altera sua conformação

Figura 1.4 - Representação da cadeia transportadora de elétrons mitocondrial, comparando a organização comum à maioria dos eucariotos com Saccharomyces cerevisiae .31

Figura 1.5 - Via biossintética da melatonina (adaptado de KOCH et al., 2009) .36

Figura 3.1 - Representação esquemática do vetor epissomal pEG(KG) contendo o gene SNCA.

Figura 3.2 - Representação esquemática do vetor integrativo pASMT-1 contendo o gene humano ASMT regulado pelo promotor GAL10

Figura 3.3 - Representação esquemática do vetor recombinante pSNCA2, obtido a partir da clonagem do gene $S N C A$ com a expressão regulada pelo promotor GAL10 .47

Figura 3.4 - Representação esquemática do vetor recombinante pSNCA3, obtido a partir da clonagem do gene SNCA com a expressão regulada pelo promotor GPD1

Figura 3.5 - Representação esquemática do vetor recombinante pSNCA4, obtido a partir da clonagem do gene SNCA com a expressão regulada por TEF1

Figura 3.6 - Representação esquemática do vetor integrativo pMLT6 contendo o gene AANAT com a expressão regulada pelo promotor GAL1O

Figura 3.7 - Representação esquemática do vetor integrativo pMLT10, contendo os genes $A S M T$ e $P A A 1$ com a expressão regulada pelo promotor GAL10 .51

Figura 4.1 - Teste de crescimento em meio rico respiratório envolvendo as linhagens W3031A, PD2 (pSNCA2), PD3 (pSNCA3) e PD4 (pSNCA4) .53

Figura 4.2 - Teste de crescimento em meio mínimo respiratório envolvendo as linhagens W303-1A e PD1 (pEG(KG)-SNCA) .54 
Figura 4.3 - Desafio com menadiona $(750 \mu \mathrm{M})$ das linhagens W303 e PD1 (pEG(KG)-SNCA) com pré-crescimento em meio mínimo com glicose (apenas W303, esquerda) ou com galactose

Figura 4.4 - Ensaio de crescimento por diluições seriadas, em glicose (meio fermentável) e em etanol glicerol (meio seletivo respiratório), das linhagens W303 e PD1, desafiadas com $750 \mu \mathrm{M}$ de menadiona

Figura 4.5 - Teste de crescimento em meio mínimo, seletivo para atividade respiratória, envolvendo as linhagens W303-1A e MLT10

Figura 4.6 - Desafio das linhagens W303 e MLT10 com $\mathrm{H}_{2} \mathrm{O}_{2}(0,5 \mathrm{mM})$

Figura 4.7 - Desafio das linhagens W303 e MLT10 com menadiona (750 $\mu \mathrm{M})$

Figura 4.8 - Ensaio de crescimento por diluições seriadas, em glicose (meio fermentável) e em etanol-glicerol (meio respiratório), das linhagens W303-1A e MLT10, após desafio com $750 \mu \mathrm{M}$ menadiona

Figura 4.9 - Ensaio de crescimento por diluições seriadas mostram o efeito protetor da melatonina em células expressando $\alpha$-sinucleína

Figura 4.10 - Teste de crescimento em meio mínimo, seletivo para atividade respiratória, envolvendo as linhagens W303-1A, W303 contendo o vetor vazio $\mathrm{pEG}(\mathrm{KG})$ e PD1(pEG(KG)-SNCA), com pré-crescimento em meio mínimo com galactose, contendo, ou não, $10 \mu \mathrm{M}$ melatonina (mlt)

Figura 4.11 - Desafio das linhagens W303 (WT) e PD1 com menadiona (750 $\mu \mathrm{M})$ após prétratamento com $10 \mu \mathrm{M}$ melatonina

Figura 4.12 - Efeito protetor da melatonina em células expressando $\alpha$-sinucleína após desafio com $750 \mu \mathrm{M}$ menadiona

Figura 4.13 - Desafio da linhagem PD1 com menadiona (750 $\mu \mathrm{M})$, após pré-tratamento com $10 \mu \mathrm{M}$ ou $100 \mu \mathrm{M}$ melatonina .66

Figura 4.14 - Atividade do complexo III (redução de citocromo $c$ ) de mitocôndrias isoladas de W303 (WT) e PD1, suplementadas com $10 \mu \mathrm{M}$ melatonina (MLT) ( $\mu$ mol cit $c$ reduzido• $\min ^{-1} \cdot \mathrm{mg} \operatorname{prot}^{-1}$ ) 
Figura 4.15 - Atividade do complexo IV (oxidação de citocromo $c$ reduzido) de mitocôndrias isoladas de W303 (WT) e PD1, suplementadas com $10 \mu \mathrm{M}$ melatonina (MLT) (nmol cit $c$ oxidado $\bullet \mathrm{min}^{-1} \bullet \mathrm{mg} \operatorname{prot}^{-1}$ ) .68

Figura 4.16 - Oxidação do NADH medida pelo consumo de oxigênio $\left(\right.$ nmol $\bullet \mathrm{mg} \operatorname{prot}^{-1} \cdot \mathrm{min}^{-1}$ ) de mitocôndrias extraídas de W303 (WT) e PD1, suplementadas com $10 \mu \mathrm{M}$ melatonina (MLT) 


\section{LISTA DE TABELAS}

Tabela 3.1 - Linhagens de S. cerevisiae, com seus respectivos genótipos, utilizadas neste trabalho

Tabela 3.2 - Sequência dos oligonucleotídeos utilizados para clonagem do gene $S N C A$ em vetores integrativos de expressão

Tabela 3.3 - Sequência dos oligonucleotídeos utilizados para clonagem do gene PAAl em vetores de expressão 48

Tabela 3.4 - Sequência dos oligonucleotídeos utilizados para clonagem do gene ASMT em vetores de expressão 49

Tabela 3.5 - Sequência dos oligonucleotídeos utilizados para clonagem do cassete de expressão GAL10-ASMT no vetor recombinante pMLT6

Tabela 4.1 - Tempos de geração em meio rico respiratório das linhagens W303, PD2, PD3 e PD4

Tabela 4.2 - Tempos de geração em meio mínimo com seleção para atividade respiratória das linhagens W303 e PD1

Tabela 4.3 - Tempos de geração em meio rico respiratório das linhagens W303 e MLT10 ..58

Tabela 4.4 - Tempos de geração em meio mínimo respiratório das linhagens W303 (WT) e PD1, com pré-crescimento em meio mínimo com galactose, contendo ou não $10 \mu \mathrm{M}$ melatonina $(\mathrm{n}=3)$. $\mathrm{L}=$ leucina 


\section{LISTA DE ABREVIATURAS}

AANAT - arilalquilamina- $N$-acetiltransferase

$\mathrm{AD}$ - mal de Alzheimer (do inglês, Alzheimer's disease)

ADP - adenosina difosfato

$\alpha$-sin $-\alpha$-sinucleína

$A S M T$ - gene humano que codifica a enzima HIOMT

ATP - adenosina trifosfato

$\mathrm{CaCl}_{2}$ - cloreto de cálcio

cDNA - DNA complementar

Cit $c$ - citocromo $c$

CoQ - coenzima $\mathrm{Q}$

$\mathrm{CoQH}_{2}-$ coenzima $\mathrm{Q}$ reduzida

COX - citocromo $c$ oxidase

$\mathrm{CTe}^{-}$- cadeia transportadora de elétrons

DOPA - dopamina

DNA - ácido desoxirribonucleico

$\mathrm{e}^{-}-$elétron

FAD - dinucleotídeo de flavina-adenina oxidado

$\mathrm{FADH}_{2}$ - dinucleotídeo de flavina-adenina reduzido

GABA - ácido gama-aminobutírico

GAL1O - promotor forte ativado por galactose

GPD1 - promotor forte gliceraldeído-3-fosfato desidrogenase.

$\mathrm{KPi}$ - fosfato de potássio

$\mathrm{H}^{+}-$próton

$\mathrm{H}_{2} \mathrm{O}$ - água 
$\mathrm{H}_{2} \mathrm{O}_{2}$ - peróxido de hidrogênio

HA - hemaglutinina da influenza humana

His - histidina

HIOMT - hidroxiindol-O-metil-transferase

L-dopa - levodopa

MLT - melatonina

$\mathrm{NAD}^{+}$- dinucleotídeo de nicotinamina-adenina oxidado

$\mathrm{NADH}$ - dinucleotídeo de nicotinamina-adenina reduzido

$\mathrm{NADPH}$ - dinucleotídeo de nicotinamina-adenina fosfato reduzido

$N S F$ - fator sensível a N-etilmaleimida (do inglês, $N$-ethylmaleimide-sensitive factor)

$P A A 1$ - gene de $S$. cerevisiae que codifica a enzima scAANAT

PCR - reação da polimerase em cadeia

PD - mal de Parkinson (do inglês, Parkinson's disease)

pDNA - DNA plasmidial

prot - proteínas

$\mathrm{O}_{2}{ }^{--}$- ânion superóxido

$\mathrm{O}_{2}$ - oxigênio molecular

$\mathrm{OH}^{*}$ - radical hidroxila

RBM - do inglês, REM sleep behavior disorder

REM - do inglês, rapid eye-moviment

RNA - ácido ribonucleico

rRNA - RNA ribossômico

ROS - espécies reativas de oxigênio (do inglês, reactive oxygen species)

scAANAT - arilalquilamina- $N$-acetiltransferase de $S$. cerevisiae

SNARE - receptor para ancoragem de NSF solúvel (do inglês, soluble NSF attachment receptor) 
SNC - sistema nervoso central

$S N C A$ - gene humano que codifica a proteína $\alpha$-sinucleína

TEF1 - promotor ativado pelo fator de elongação de tradução 1- $\alpha$ (codificado por TEF2)

t-RNA - RNA transportador

UFC - unidade formadora de colônia 


\section{LISTA DE SÍMBOLOS}
A - Adenina
E - Glutamato
$\mathrm{G}$ - Glicina
$\mathrm{K}$ - Lisina
L - Leucina
P - Prolina
$\mathrm{T}$ - Treonina
V - Valina 


\section{SUMÁRIO}

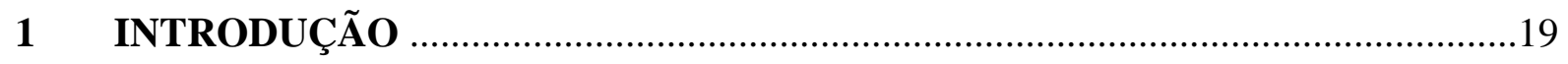

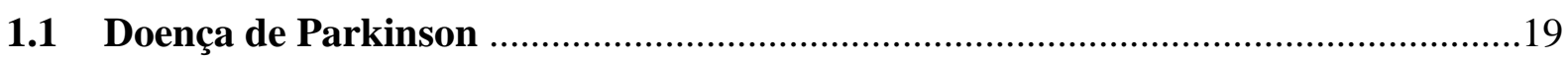

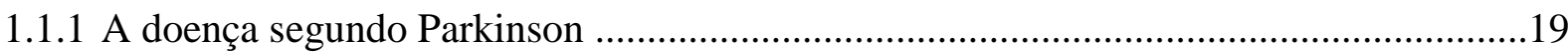

1.1.2 Aspectos neurofisiológicos da doença de Parkinson ...................................................20

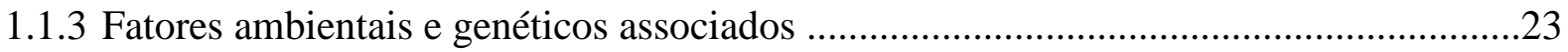

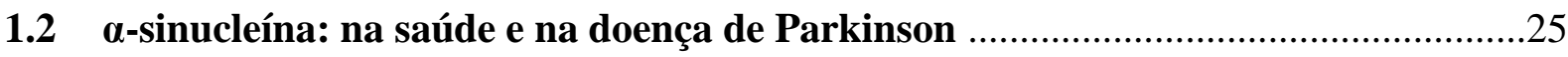

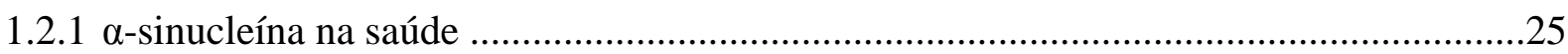

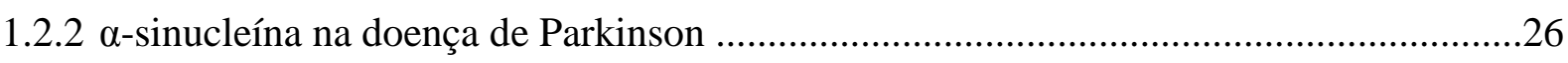

1.3 Mitocôndria: origem, função e relação com a doença de Parkinson ......................28

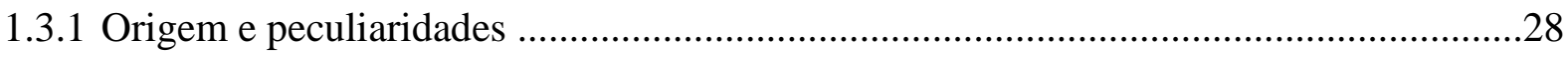

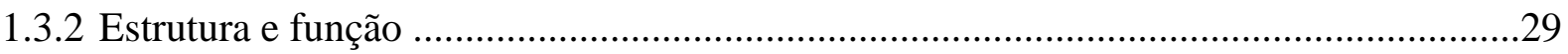

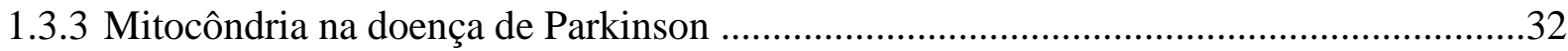

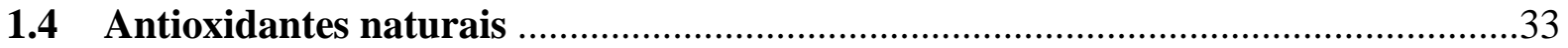

1.4.1 Melatonina: uma molécula, múltiplas funções ........................................................35

1.5 Saccharomyces cerevisiae como modelo para o estudo de doenças ...........................38

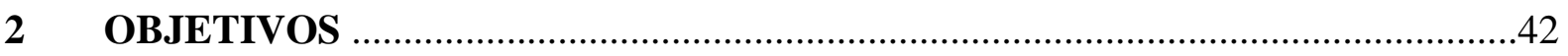

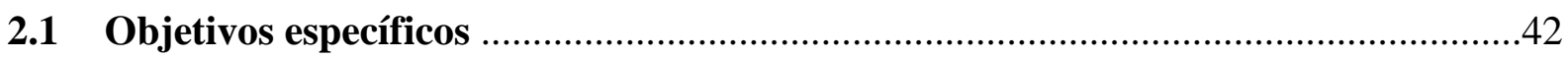

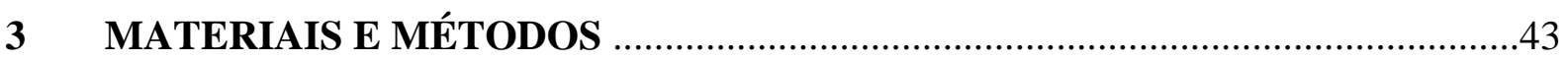

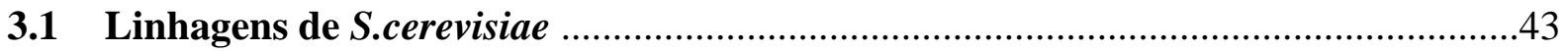

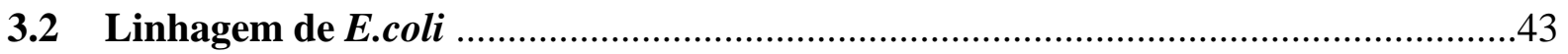

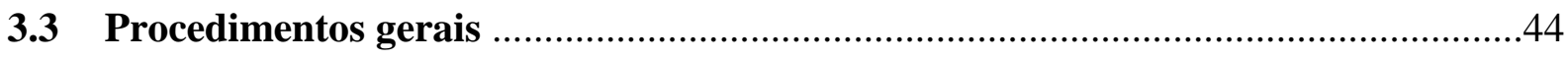

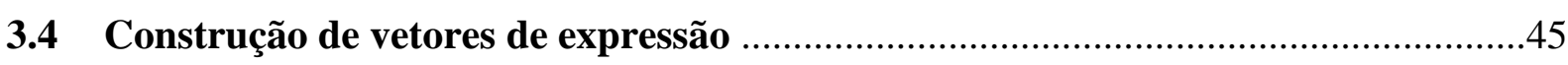

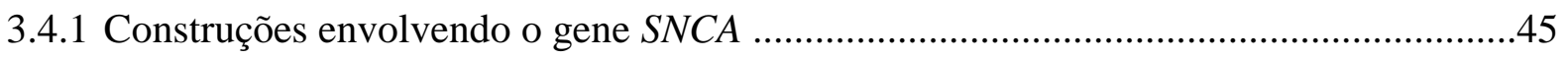

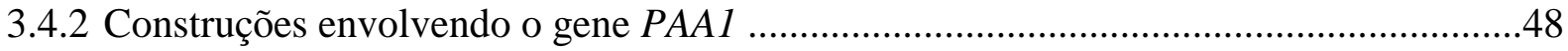

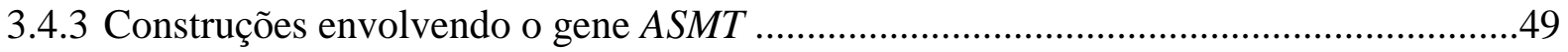

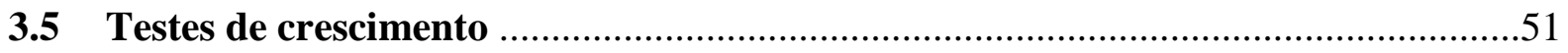

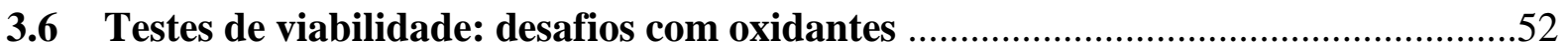

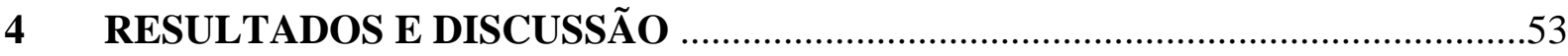

4.1 Ensaios de crescimento e desafios com oxidantes ....................................................53

4.1.1 Leveduras, expressando múltiplas cópias do gene SNCA, apresentam crescimento reduzido em meio respiratório 
4.1.2 Leveduras parkinsonianas exibem maior sensibilidade ao estresse oxidativo causado por menadiona .55

4.1.3 A produção de melatonina não interfere no crescimento de leveduras parentais .57

4.1.4 A produção de melatonina confere menor sensibilidade ao estresse oxidativo causado por peróxido de hidrogênio e por menadiona

4.1.5 A suplementação com dose farmacológica de melatonina confere proteção aos efeitos citotóxicos de $\alpha$-sinucleína .61

4.2 Medidas de capacidade respiratória .66

4.2.1 $\alpha$-sinucleína diminui atividade do complexo III, que é recuperada por melatonina .66

4.2.2 Melatonina recupera a atividade do complexo IV de leveduras parkinsonianas ............68

4.2.3 Melatonina aumenta o consumo de oxigênio pelas mitocôndrias .................................69

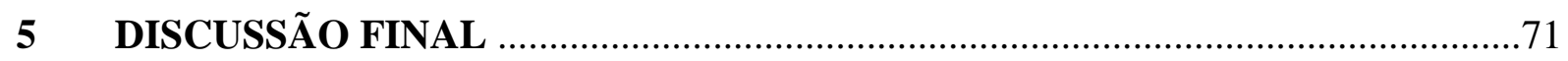

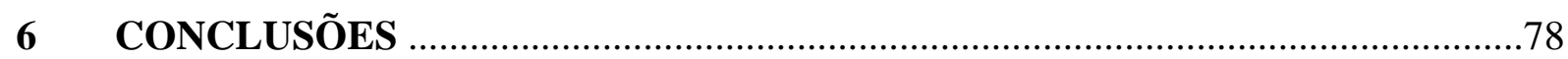

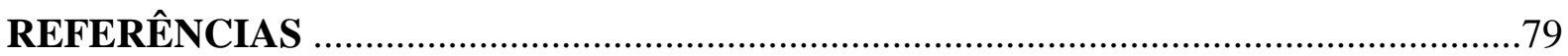




\section{INTRODUÇÃO}

\subsection{Doença de Parkinson}

\subsubsection{A doença segundo Parkinson}

Em 1817, James Parkinson descreveu, pela primeira vez, a doença neurodegenerativa que depois foi batizada com seu nome, no brilhante ensaio "An essay on the shaking palsy", originalmente definida como "paralisia trêmula" (do latim, paralysis agitans; do inglês, shaking palsy).

A doença se desenvolve muito lentamente. Em seu ensaio, Parkinson observou seis casos, três dos quais pessoalmente tratou, descrevendo a progressão da doença, "tão extremamente lenta que raramente acontece de o paciente ter alguma lembrança precisa do período em que se iniciou". O primeiro sintoma perceptível da patologia é uma leve sensação de fraqueza com leve tremor em alguma parte particular do corpo, mais comumente em uma das mãos ou braços, que lentamente aumenta e, em um período incerto, começa a se manifestar em outra parte do corpo. Após alguns meses, o doente apresenta crescente dificuldade em manter uma postura ereta. Então, uma das pernas passa a apresentar um tênue tremor e sofre de fadiga antes da outra perna; e em alguns meses, esta também sofre com tremores e de uma perda de tônus muscular similares.

Com o desenvolvimento desses sintomas, o paciente experimentou apenas um pouco de desconforto e, "como se tornado amigo da rigidez habitual de seus membros, frequentemente se esquece de estar doente, exceto quando é lembrado pela desestabilidade de suas mãos enquanto escreve". Mas, com a progressão da doença, qualquer tarefa se torna mais difícil, "as mãos falhando em responder com precisão ao que dita seu desejo". As pernas não se levantam mais como antes, "caminhar se torna uma tarefa que não pode ser executada sem uma atenção considerável [...] que todo cuidado é necessário para evitar as quedas frequentes".

Os inconvenientes aumentam diariamente: "a submissão dos membros às direções da vontade dificilmente são obtidos nas tarefas mais ordinárias da vida”. Escrever e ler se tornam difíceis devido aos tremores das mãos e, frequentemente, o paciente experimenta uma diminuição nos tremores para então recomeçarem em outra parte do corpo. A propensão a se inclinar se torna tão grande que o paciente tem dificuldades em não cair quando está de pé. 
O sono também é afetado: os tremores dos membros acordam os pacientes. Há maior dificuldade em conseguir levar os alimentos à boca e o paciente é obrigado a delegar sua alimentação a outros. Os músculos dos intestinos deixam de funcionar corretamente e necessitam de ajuda mecânica para expulsão das fezes. $\mathrm{O}$ paciente passa a andar com grande dificuldade mesmo com bengala.

"Suas palavras são raramente inteligíveis; e ele não pode mais se alimentar, pois [...] é tanta a ação muscular [...] que a comida é dificilmente retida na boca durante a mastigação; então é dificilmente engolida. Agora também, pela mesma causa, outra situação desagradável ocorre: a saliva não consegue ser direcionada para a parte posterior da boca, e continuamente vaza da boca" (PARKINSON, 1817).

As dificuldades aumentam ainda mais, e os músculos raramente respondem à sua vontade. Os tremores se tornam mais fortes e raramente param, impedindo o paciente de dormir. Ele perde a capacidade de se articular e de evacuar voluntariamente.

"E finalmente, a constante sonolência, com um leve delírio, e outros marcadores de extrema exaustão, anunciam a tão desejada libertação".

\subsubsection{Aspectos neurofisiológicos da doença de Parkinson}

A doença de Parkinson (PD, do inglês Parkinson's disease) caracteriza-se, clinicamente, por bradicinesia (lentidão anormal dos movimentos musculares voluntários, incluindo a fala), tremor em repouso (tremor anormal de membros do corpo relaxados, apoiados ou em repouso) e rigidez postural, caracterizada pela perda da flexibilidade de movimentos e resistência de um membro a dado movimento (JANKOVIC, 2008). Essas alterações motoras devem-se, em grande parte, à perda de neurônios dopaminérgicos da substância negra (do latim, substantia nigra).

A substância negra (figura 1.1) é um dos gânglios basais do mesencéfalo, relacionada à recompensa, vício e movimento. Muitas de suas funções são mediadas pelo tecido estriado. É rica em neurônios dopaminérgicos contendo neuromelanina, razão pela qual aparece escurecida em cortes histológicos. 
Figura 1.1 - A substância negra é um dos gânglios basais mesencefálicos.

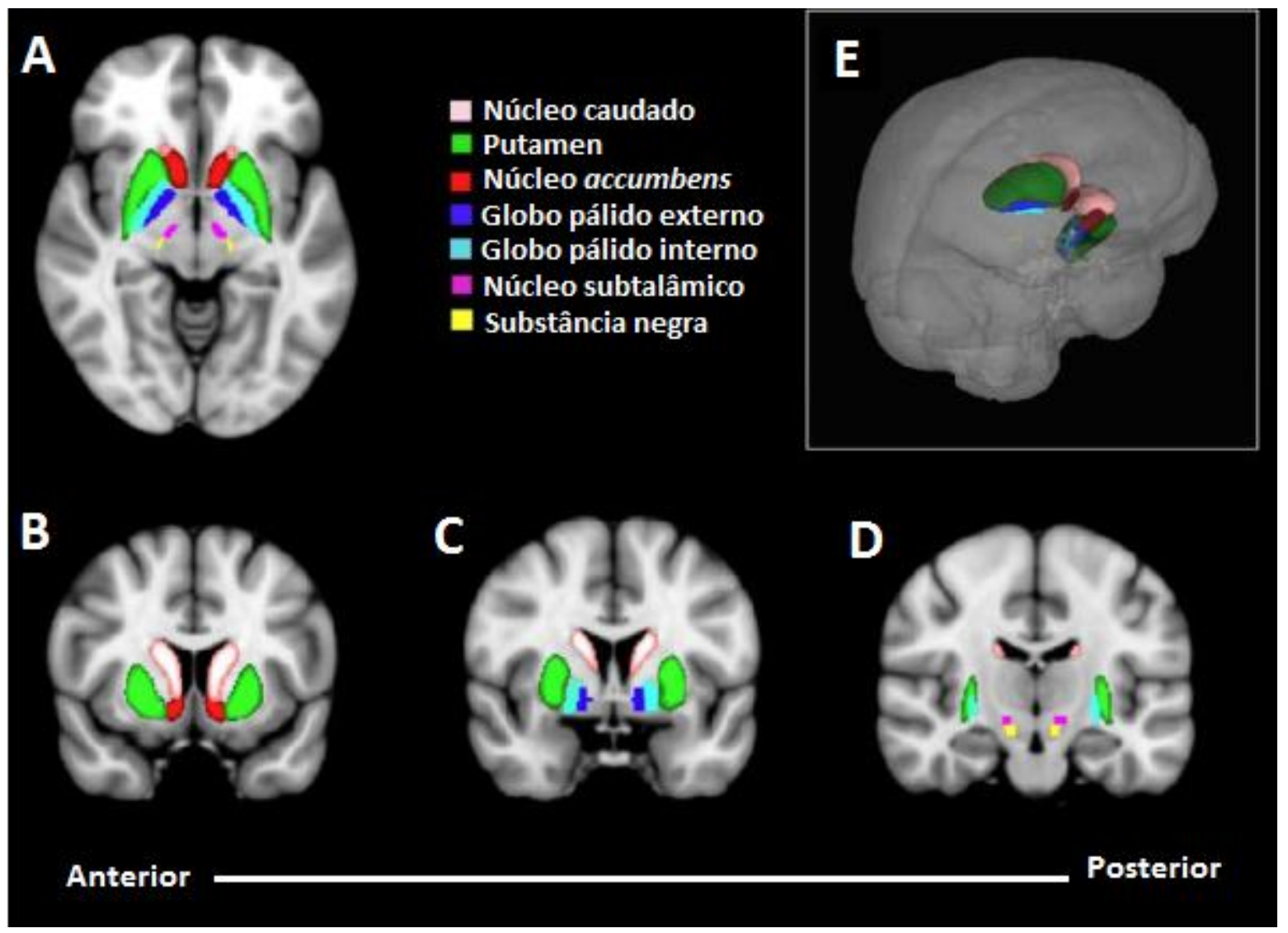

Visão horizontal (A), coronal (B-D) e representação 3-D (E) dos gânglios basais do mesencéfalo human. As sub-regiões estão coloridas conforme a legenda.

Fonte: Adaptado de Borsook et al. (2010).

A região pars compacta da substância negra, cuja perda de neurônios é relacionada ao desenvolvimento de PD, está envolvida no processamento temporal (MATELL; MECK, 2000) e na aprendizagem de respostas a novos estímulos (SCHULTZ, 2007) e, indiretamente, no controle motor fino (PIOLI et al., 2008). Acredita-se estar envolvida também na regulação do ciclo sono-vigília (LIMA et al., 2007). É composta majoritariamente de neurônios dopaminérgicos, cujos corpos celulares são ricos em melanina e os dendritos são longos e bem arborizados, se distribuindo por muitas estruturas cerebrais. Através da via nigroestriatal, os axônios desses neurônios inervam o estriado, núcleo subtalâmico e a substância negra pars reticulata, onde liberam dopamina, mediando a resposta estímulos ambientais (revisto por SCHULTZ, 2007).

A dopamina (DOPA) é um neurotransmissor envolvido em diversas funções cerebrais, como emoção e cognição e atua, indiretamente, no controle motor pela estimulação do estriado (CROCKER et al., 1994). É um composto químico pertencente à família das catecolaminas, sintetizada a partir do aminoácido L-tirosina, que é hidroxilado, pela tirosina 
hidroxilase, no precursor L-DOPA (3,4-dihidroxifenilalanina), o qual será descarboxilado em dopamina (revisto por Molinoff e Axelrod, 1971). Após síntese nos neurônios nigrais, DOPA é acondicionada em vesículas sinápticas, que irão liberar o neurotransmissor na fenda sináptica quando houver um potencial de ação (JAHN; SÜDHOF, 1993). DOPA se liga a receptores pós-sinápticos, propagando a diante o sinal da célula pré-sináptica. Também pode se ligar a receptores pré-sinápticos para excitar ou inibir a liberação de mais DOPA da célula pré-sinática. A remoção do neurotransmissor da sinapse é feita por recaptação pela célula présináptica através de receptores e então é feita a degradação enzimática, produzindo metabólitos inativos de DOPA (AXELROD, 1971).

O acondicionamento da dopamina em vesículas ou sua degradação enzimática previnem sua oxidação, o que é importante para manutenção do estado redox celular. No citosol, DOPA é prontamente oxidada a dopamina-O-quinona que é convertida aminocromo, substância precursora da neuromelanina característica de neurônios nigrais. A neuromelanina possui um papel neuroprotetor, pois é um quelante de metais (GERLACH et al., 2003). No entanto, quando neuromelanina não é formada, aminocromo pode formar adutos com o complexo I e III mitocondriais (SEGURA-AGUILAR; LIND, 1989), causando disfunção da organela e aumentando ainda mais o estresse oxidativo. Ainda, pode formar adutos com a $\alpha$-sinucleína, desencadeando a formação de protofibrilas tóxicas (CONWAY et al., 2001), e, também, pode inativar a proteína parkina (LA VOIE et al., 2005), impedindo a reciclagem mitocondrial necessária para o controle de qualidade bioenergético. Consequentemente, pode ocorrer morte desses neurônios nigrais, ocasionando neuropatias, como PD.

Como pode ser visto em fotomicrografias de encéfalos de primatas (figura 1.2), PD se desenvolve com a perda de neurônios dopaminérgicos da substância negra pars compacta (KIM et al., 2003). Na ausência de dopamina, há maior inibição do corpo estriado, importante centro de regulação motora, o que gera as anormalidades motoras comumente observadas em indivíduos afetados pela doença (LIMONGI, 2001). No entanto, existem evidências de que outras regiões não dopaminérgicas do córtex cerebral também são afetadas: autópsias feitas por Braak e colaboradores (2003) sugerem que a patologia se inicia afetando regiões cerebrais relacionadas ao sistema olfatório e ao trato digestório, sendo que alterações olfatórias seriam consideradas os avisos que possibilitariam o diagnóstico precoce da doença. 
Figura 1.2 - Fotomicrografia do mesencéfalo de macaco com imunocoloração para a enzima tirosina hidroxilase.

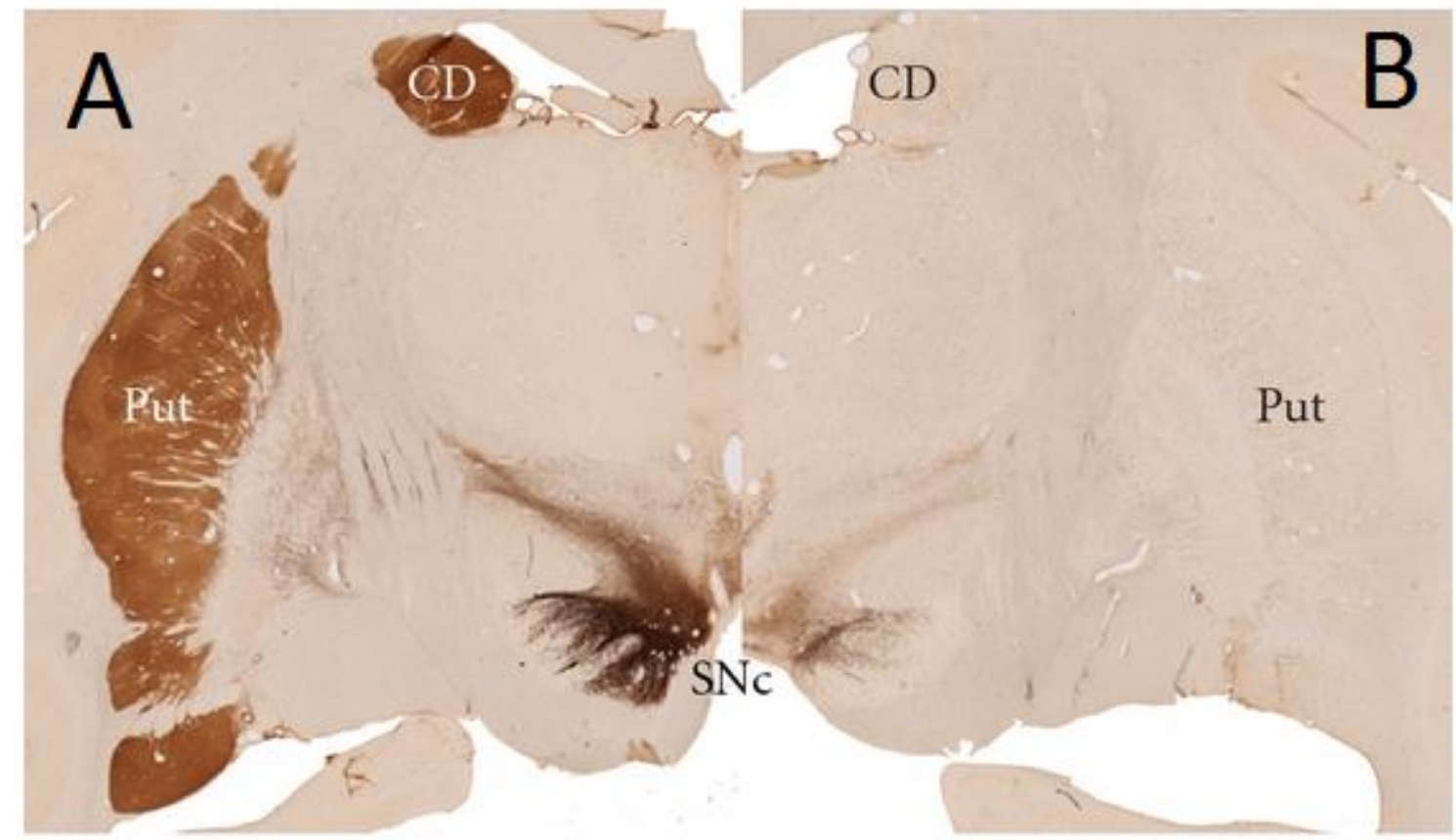

Os neurônios dopaminérgicos da substância negra pars compacta $(\mathrm{SNc})$ se projetam para o núcleo caudado (CD) e para o putamen (Put). Após tratamento com MPP (1-metil-4fenilpiridina) para modelar Parkinson (B), há uma significativa redução da imunoreatividade da enzima nessas regiões, condizente com a perda dos neurônios dopaminérgicos, se comparado ao controle (A).

Fonte: Adaptado de Blesa et al. (2012).

Algumas doenças neurodegenerativas, conhecidas como desordens parkinsonianas, apresentam manifestações clínicas similares a PD (parkinsonismo). No entanto, suas características patofisiológicas são distintas de PD e, assim, seguem diferentes padrões de neurodegeneração. PD é caracterizada pela formação de corpos de Lewy, que são agregados proteicos compostos predominantemente de $\alpha$-sinucleína (SPILLANTINI et al., 1997). Em outras doenças parkinsoninanas, como degeneração corticobasal, há a formação de agregados neurofibrilares da proteína ligante de microtúbulos Tau, e não de $\alpha$-sin (BOEVE, 2011). Entretanto, a correta diferenciação entre as patologias só é possível em exames post mortem, o que diminui a eficácia de seu tratamento.

\subsubsection{Fatores ambientais e genéticos associados}

Grande parte dos casos de PD é idiopática: apenas cerca de $15 \%$ dos pacientes possuem histórico familiar da doença (revisto por HUANG et al., 2004). Diversos estudos 
epidemiológicos buscam a identificação de fatores ambientais e genéticos que influenciem o aparecimento e desenvolvimento da doença.

Vários estudos demonstraram associação de exposição a pesticidas com 0 desenvolvimento de PD: por exemplo, rotenona, composto orgânico produzido por raízes de algumas plantas, é utilizado como piscicida e inseticida, e paraquat é utilizado para matar ervas daninhas. Esses compostos, quando ministrados a camundongos e primatas, resultam em neurodegeneração semelhante à PD (BETARBET et al., 2000; SHERER et al., 2003a), sendo inclusive utilizados para modelar a doença nesses organismos. Tanner e colaboradores (2009) mostraram que há forte correlação entre o uso na agricultura de rotenona e de paraquat com o desenvolvimento de PD em humanos. Nos anos 1970 e 1980, usuários de heroína foram expostos acidentalmente a um contaminante da droga, conhecido como MPTP (1-metil4-fenil-1,2,3,6-tetrahidropiridina) e desenvolveram parkinsonismo (LANGSTON et al., 1983). Esses três compostos são tóxicos às mitocôndrias, pois se ligam ao complexo I e interferem no transporte de elétrons e na fosforilação oxidativa, causando estresse oxidativo (AYALA et al., 2007).

No final dos anos 1990 e início dos 2000, alguns fatores genéticos relevantes ao desenvolvimento de PD começaram a ser descritos com base no estudo de famílias com histórico da doença. Mutações nos genes Parkin, PINK-1 (PARK6) e DJ-1 (PARK7) estão relacionadas a casos autossômico-recessivos de PD. A proteína Parkina é uma E3 ubiquitina ligase que atua em diversos substratos promovendo sua degradação via proteassoma (SHIMURA et al., 2000), como também no processo de autofagia mitocondrial, conhecida como mitofagia (NARENDRA et al., 2008), sendo importante no controle de qualidade bioenergético e mitocondrial (revisto por Exner e colaboradores, 2012). Pink-1 é uma quinase mitocondrial que parece ser ativada quando há despolarização da membrana mitocondrial, mediando a mitofagia dependente de Parkina (NARENDRA et al., 2010). DJ-1 é um gene nuclear cujo produto se localiza na mitocôndria e está relacionado à sensibilidade ao estresse oxidativo (MARTINAT et al., 2004). Recentemente, foi visto que DJ-1p controla negativamente a ativação de Parkina, pois consegue diminuir o estresse oxidativo mitocondrial (JOSELIN et al., 2012). Esses resultados indicam que a manutenção da função mitocondrial tem importância vital para a progressão de PD.

Em 1997, em uma família com herança dominante de PD, Polymeropoulos e colaboradores descreveram uma mutação missense (A53T) no gene SNCA, que codifica a proteína $\alpha$-sinucleína, sendo essa proteína o componente predominante dos corpos de Lewy 
(SPILLANTINI et al., 1997). Duplicações, triplicações e outras mutações no gene $S N C A$ (A30P e E46K) também foram identificadas em casos familiares da doença (CHARTIERHARLIN et al., 2004; KRUGER et al., 1998; SINGLETON et al., 2003; ZARRANZ et al., 2004).

\section{2 $\alpha$-sinucleína: na saúde e na doença de Parkinson}

Uma característica comum em doenças neurodegenerativas é a formação de agregados proteicos, que resultam em disfunção neuronal e, eventualmente, morte celular. Fortes evidências mostram que o acúmulo da proteína $\alpha$-sinucleína $(\alpha$-sin), decorrentes de mutações ou alterações na expressão do gene $S N C A$, está relacionado ao aparecimento e à progressão da doença de Parkinson. De fato, observou-se que a formação desses agregados na substância negra de camundongos transgênicos expressando altos níveis de $\alpha$-sin humana estava relacionada à perda motora progressiva, característica da patologia que é agravada com o envelhecimento (HANSEN et al., 2013).

\subsection{1 $\alpha$-sinucleína na saúde}

A proteína $\alpha$-sin foi isolada pela primeira vez em 1988, de neurônios colinérgicos da raia Torpedo californica por Maroteaux e colaboradores. Como ela estava localizada em vesículas sinápticas e em porções nucleares, recebeu o nome de sinucleína. Em 1998, Lavedan e colaboradores descreveram mais três proteínas dessa família ( $\beta$-sinucleína, $\gamma$ sinucleína e sinoretinina), sendo que apenas $\alpha$-sin e $\beta$-sin são expressas no cérebro humano. Todas essas quatro sinucleínas apresentam, em sua porção $\mathrm{N}$-terminal, seis repetições imperfeitas da sequência KTKEGV (MAROTEAUX; CAMPANELLI; SCHELLER, 1988). Entretanto, apenas $\alpha$-sin é capaz de formar agregados resistentes a detergente, pois possui uma região altamente hidrofóbica em seu centro (GIASSON et al., 2001), necessária para oligomerização e formação de fibrilas característica dos corpos de Lewy.

Apesar de suas funções celulares ainda não estarem totalmente esclarecidas, $\alpha$-sin interage diretamente com lipídios e com membranas. A proteína tem 140 resíduos e está relacionada à plasticidade de membranas da siríngide de pássaros (CLAYTON; GEORGE, 1998). Segundo Weinreb e colaboradores (1996), ela apresenta uma conformação nativa desdobrada (figura 1.3, A), mas, ao entrar em contato com pequenas vesículas, adquire uma 
conformação secundária de $\alpha$-hélice que permite sua interação com fosfolipídios aniônicos (figura 1.3, B) (DAVIDSON et al., 1998). Essa interação ocorre através da porção N-terminal de $\alpha$-sin, que é extremamente hidrofóbica, enquanto a porção C-terminal permanece livre no citoplasma para poder se ligar a outras proteínas de membrana (ELIEZER et al., 2001).

Há evidências crescentes de que $\alpha$-sin é necessária para o funcionamento adequado do complexo de Golgi e do tráfego de vesículas sinápticas (COOPER et al., 2006). Já foram demonstradas interações com tubulina (ALIM et al., 2002), condizente com sua função no tráfego vesicular anterógrado. $\alpha$-sin é expressa predominantemente nos terminais présinápticos do sistema nervoso central (SNC) de mamíferos (JAKES; SPILLANTINI; GOEDERT, 1994), e, consistente com sua atuação na liberação de neurotransmissores, existem evidências de que esteja envolvida na formação de complexos SNARE (do inglês, soluble NSF attachment receptor) que mediariam a fusão das vesículas às sinapses durante a exocitose de neurotransmissores (BONINI; GIASSON, 2005). Acredita-se que $\alpha$-sin atue no desenvolvimento de neurônios e na regulação da liberação de neurotransmissores (NORRIS; GIASSON; LEE, 2004), pois sua seus níveis de expressão são mais altos em regiões de rearranjo pré-sináptico, consistente com a hipótese plasticidade neural (GEORGE et al., 1995).

\subsection{2 $\alpha$-sinucleína na doença de Parkinson}

A capacidade de interação com superfícies hidrofóbicas permite que $\alpha$-sin desempenhe seu papel no tráfego de vesículas, mas, quando há mutações nessa proteína, podem-se desenvolver sinucleinopatias.

As três mutações descritas em PD familiar alteram a estrutura de $\alpha$-sin de maneiras distintas. A mutação A53T expande o domínio hidrofóbico (BIERE et al., 2000) e desestabiliza sua $\alpha$-hélice, que passa a ter a conformação para folha- $\beta$ (figura 1.3, C), formando oligômeros, que podem formar os corpos de Lewy (SPILLANTINI et al., 1997). A mutação E46K potencializa a interação intermolecular de $\alpha$-sin com fosfolipídios, o que facilitaria a formação de dímeros e de oligômeros tóxicos (figura 1.3, C) (ROSPIGLIOSI et al., 2009). Essas duas mutações conferem ganho de função a $\alpha$-sin, pois aumenta sua afinidade por membranas, alterando a curvatura das vesículas e, assim, dificultar a sua fusão com membranas maiores (CHERNOMORDIK et al., 1995), como as membranas présinápticas, o que impediria a liberação de neurotransmissores. 
Figura 1.3 - A interação de $\alpha$-sinucleína com lipídios altera sua conformação.
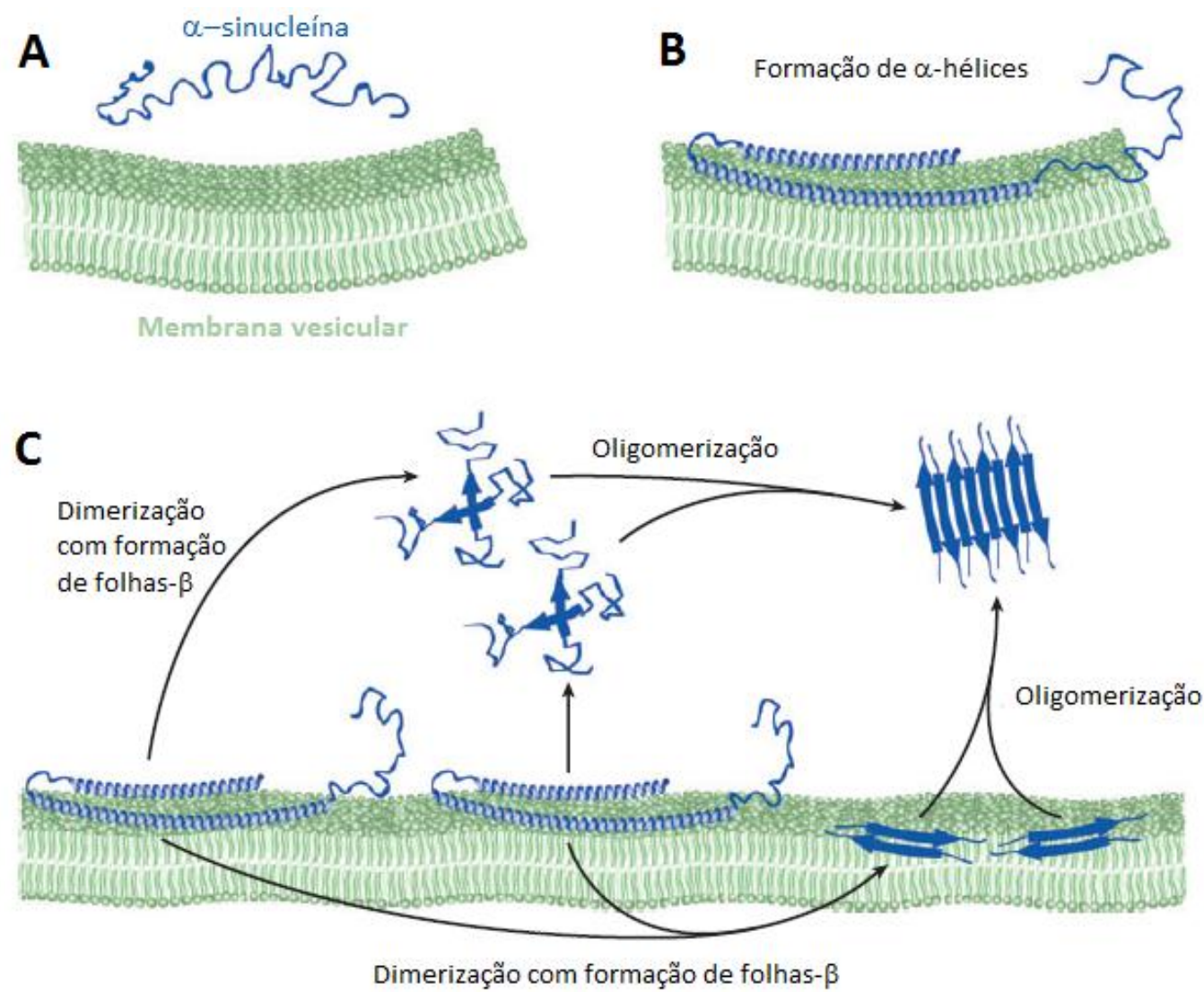

Em solução, $\alpha$-sin encontra-se naturalmente desdobrada (A), mas, ao interagir com membranas de vesículas contendo fosfolipídios aniônicos, a região N-terminal da proteína forma duas hélices, as quais permitem sua associação com a superfície vesicular (B). Mutações (A53T e E46K) e aumento na concentração de $\alpha$-sin (multiplicação do locus gênico) estabilizam as interações entre membranas e $\alpha$-sin, facilitando a formação de dímeros com estrutura secundária de folha- $\beta$ e posterior oligomerização. Os oligômeros se depositam em corpos de Lewy.

Fonte: Adaptado de Auluck, Caraveo e Lindquist (2010).

Já a mutação A30P desestabiliza a $\alpha$-hélice e reduz a afinidade de $\alpha$-sin por fosfolipídios, reduzindo a agregação in vitro (YONETANI et al., 2009). Segundo Auluck, Caraveo e Lindquist (2010), as vesículas poderiam se degradar precocemente ou, após fusão com a membrana alvo, poderiam não se formar novamente, o que poderia prejudicar a liberação de neurotransmissores na sinapse.

No entanto, não apenas mutações na sequência de aminoácidos do gene SNCA são responsáveis por sinucleinopatias: o aumento nos níveis de $\alpha$-sin selvagem interfere no tráfego de vesículas nos estágios iniciais das vias secretórias (COOPER et al., 2006) e é a principal causa para a formação de agregados proteicos citoplasmáticos conhecidos como corpos de Lewy (SPILLANTINI et al., 1997). Nemani e colaboradores (2010) mostraram que o acúmulo de $\alpha$-sin nos terminais sinápticos causa uma inibição na liberação de 
neurotransmissores em neurônios dopaminérgicos devido a alterações no pool vesicular sináptico, que impedem o reagrupamento das vesículas de endocitose.

Além das interações bem estabelecidas de $\alpha$-sin com vesículas, crescentes evidências apontam para uma forte interação com lipídios mitocondriais. Já foi detectada $\alpha$-sin em frações mitocondriais em diversos modelos, como homogenatos de cérebros murinos (LI et al., 2007). Essas organelas parecem ser um alvo preferencial de $\alpha$-sin, pois foi visto in vitro que a proteína se liga preferencialmente a superfícies lipídicas aniônicas (PRANKE et al., 2011), como as membranas mitocondriais, ricas em cardiolipina. Em condições fisiológicas, $\alpha$-sin parece estar relacionada com a entrega, acúmulo e controle da função mitocondrial nas sinapses, o que afetaria a liberação de neurotransmissores (NAKAMURA et al., 2011). Ellis et al. (2005) mostraram que a presença de $\alpha$-sin é necessária para a manutenção da composição lipídica e, assim, para a função mitocondrial, já que camundongos que não produziam $\alpha$-sin apresentavam anormalidades mitocondriais que resultavam em baixa atividade de complexos respiratórios. No entanto, mutações ou aumento nos níveis de expressão de $\alpha$-sin resultam em danos às mitocôndrias, resultando em alterações morfológicas e funcionais. Os aspectos patofisiológicos dessa interação serão abordados a seguir.

\subsection{Mitocôndria: origem, função e relação com a doença de Parkinson}

\subsubsection{Origem e peculiaridades}

A mitocôndria é uma organela dinâmica, central em vários processos celulares. Sua função de maior destaque é a produção de energia para a célula na forma de ATP, gerada pelo processo de fosforilação oxidativa (SARASTE, 1999). Atua em processos catabólicos e anabólicos, incluindo $\beta$-oxidação de ácidos graxos e biossíntese de grupamentos heme e ferroenxofre, importantes para o funcionamento de diversas enzimas (LILL; MÜHLENHOFF, 2006). Ainda, a mitocôndria tem um papel regulador da morte celular programada (TAIT; GREEN, 2010) e está no centro de processos de envelhecimento celular (WALLACE, 2005).

Acredita-se, segundo a teoria endossimbionte proposta por Lynn Margulis em 1970, que a mitocôndria tenha surgido da fagocitose de uma arqueobactéria anaeróbica metanogênica por uma célula eucariótica primitiva, há quase dois bilhões de anos (DOLEZAL et al., 2006), o que explicaria o fato de essa organela ainda possuir genoma e ribossomos próprios, sendo capaz de sintetizar algumas proteínas. 
Durante o processo endossimbionte, o hospedeiro fornecia, além de proteção, compostos orgânicos utilizados na produção aeróbia de ATP pelo simbionte. No entanto, este processo também produzia radicais livres pelo simbionte, o que resultou numa pressão para migração de genes do simbionte para o genoma do hospedeiro, resultando na organela conhecida como mitocôndria (ALLEN; RAVEN, 1996). Diversas evidências corroboram essa transferência gênica. Ricchetti e colaboradores (1999) identificaram sequências curtas de origem mitocondrial no genoma nuclear de leveduras Saccharomyces cerevisiae. Dessa forma, durante a evolução, diversos genes mitocondriais foram transferidos para o núcleo.

Nem todos os genes mitocondriais foram transferidos para o núcleo: as organelas conservam alguns genes essenciais para a montagem dos complexos respiratórios (WESTERMANN et al., 2010), apesar de a grande maioria de suas proteínas serem codificadas por genes nucleares e importadas para o seu interior após modificações póstraducionais. Assim, observa-se que o funcionamento da organela depende da contribuição dos genomas nuclear e mitocondrial, e a manutenção do DNA mitocondrial e sua transmissão para as mitocôndrias filhas é essencial para a qualidade bioenergética (CHEN; BUTOW, 2005).

\subsubsection{Estrutura e função}

Como discutido, a mitocôndria é uma organela peculiar, com certo grau de autonomia: com seu DNA e ribossomos próprios, pode sintetizar algumas de suas proteínas, além de passar por ciclos de fissão e fusão para gerar mitocôndrias filhas e para garantir seu controle de qualidade. Ainda, a organela está relacionada a processos de apoptose, desenvolvimento, envelhecimento e biossíntese de componentes de enzimas.

Estruturalmente, a mitocôndria é composta por duas membranas que envolvem uma matriz solúvel. Entre essas duas membranas, forma-se um espaço intermembranar, importante para a função da organela. A membrana externa, que envolve a organela como um todo, possui permeabilidade seletiva a íons e a pequenas moléculas. Em contato direto com a matriz mitocondrial, a membrana interna, impermeável a íons, possui grandes invaginações para o interior da matriz, chamadas de cristas mitocondriais (TZAGOLOFF, 1982).

Nessas cristas, voltados para a matriz, estão localizados os complexos respiratórios organizados de maneira dinâmica em potenciais de redução crescentes, formando a cadeia transportadora de elétrons mitocondrial $\left(\mathrm{CTe}^{-}\right)$. São responsáveis pela captação de elétrons de 
carreadores como $\mathrm{NADH}_{\text {e }} \mathrm{FADH}_{2}$, após a oxidação de açúcares, lipídios e proteínas, para a produção de ATP. Durante a transferência de elétrons pelos complexos, prótons são bombeados para o espaço intermembranar, formando gradiente de prótons devido às propriedades particulares de cada membrana mitocondrial (SCHAFFER; SULEIMAN, 2007).

A cadeia transportadora de elétrons é composta por cinco complexos respiratórios (I, II, III, IV, V). Em mamíferos e em vários fungos, o complexo I (NADH desidrogenase) é o maior dos cinco, com cerca de 40 subunidades. Em Saccharomyces cerevisiae, no entanto, ele não está organizado em um complexo proteico de múltiplas subunidades (GRANDIERVAZEILLE et al., 2001). A levedura possui três enzimas NADH desidrogenase na membrana interna: uma interna (Ndilp), com seu sítio catalítico orientado para a matriz mitocondrial, que oxida o NADH mitocondrial (DE VRIES; MARRES, 1987; MARRES; DE VRIES; GRIVEL, 1991), e outras duas externas (Nde1p e Nde2p), orientadas para o espaço intermembranar, que oxidam diretamente o NADH citosólico (LUTTIK et al., 1998; SMALL; MCALISTER-HENN, 1998).

A fosforilação oxidativa (figura 1.4), processo de produção de ATP acoplada à redução de oxigênio $\left(\mathrm{O}_{2}\right)$ em água $\left(\mathrm{H}_{2} \mathrm{O}\right)$, inicia-se com a transferência de elétrons na cadeia respiratória a partir da oxidação dos carreadores hidrossolúveis $\mathrm{NADH}$ e $\mathrm{FADH}_{2}$. Esses elétrons são liberados de biomoléculas oxidadas e, então, captados pelo $\mathrm{NAD}^{+}$e o FAD. O complexo I (NADH desidrogenase) recebe os elétrons da oxidação do NADH, reciclando o $\mathrm{NAD}^{+}$, enquanto o complexo II (succinato desodrogenase) oxida $\mathrm{FADH}_{2}$, reciclando o FAD. Esses elétrons são transferidos unidirecionalmente em direção a potenciais crescentes de redução: primeiro para a ubiquinona, originando as formas parcialmente reduzida (semiquinona) e totalmente reduzida (ubiquinol). Ubiquinol transfere os elétrons para o complexo III (citocromo $c$ redutase ou complexo citocromo $b c 1$ ) que, em seguida, os transfere para o citocromo $c$, reduzindo-o. Os elétrons passam, então, para o complexo IV (citocromo $c$ oxidase), que, na etapa final da $\mathrm{CTe}^{-}$, oxida o citocromo $c$ reduzido e reduz o $\mathrm{O}_{2}$ a $\mathrm{H}_{2} \mathrm{O}$ (SARASTE, 1999).

A energia livre do fluxo de elétrons pela $\mathrm{CTe}^{-}$é conservada pelo bombeamento de prótons $\left(\mathrm{H}^{+}\right)$da matriz mitocondrial para o espaço intermembranar, através dos complexos I, III e IV, criando um gradiente de $\mathrm{H}^{+}$, que é mantido pela impermeabilidade da membrana interna. O gradiente eletroquímico é aproveitado para a síntese de ATP pela ATP sintase (complexo V), que atua como uma turbina: a força motriz gerada pela passagem de $\mathrm{H}^{+}$produz 
movimento na estrutura da ATP sintase, que é utilizada para a fosforilação do ADP em ATP (SARASTE, 1999).

Figura 1.4 - Representação da cadeia transportadora de elétrons mitocondrial, comparando a organização comum à maioria dos eucariotos com Saccharomyces cerevisiae.

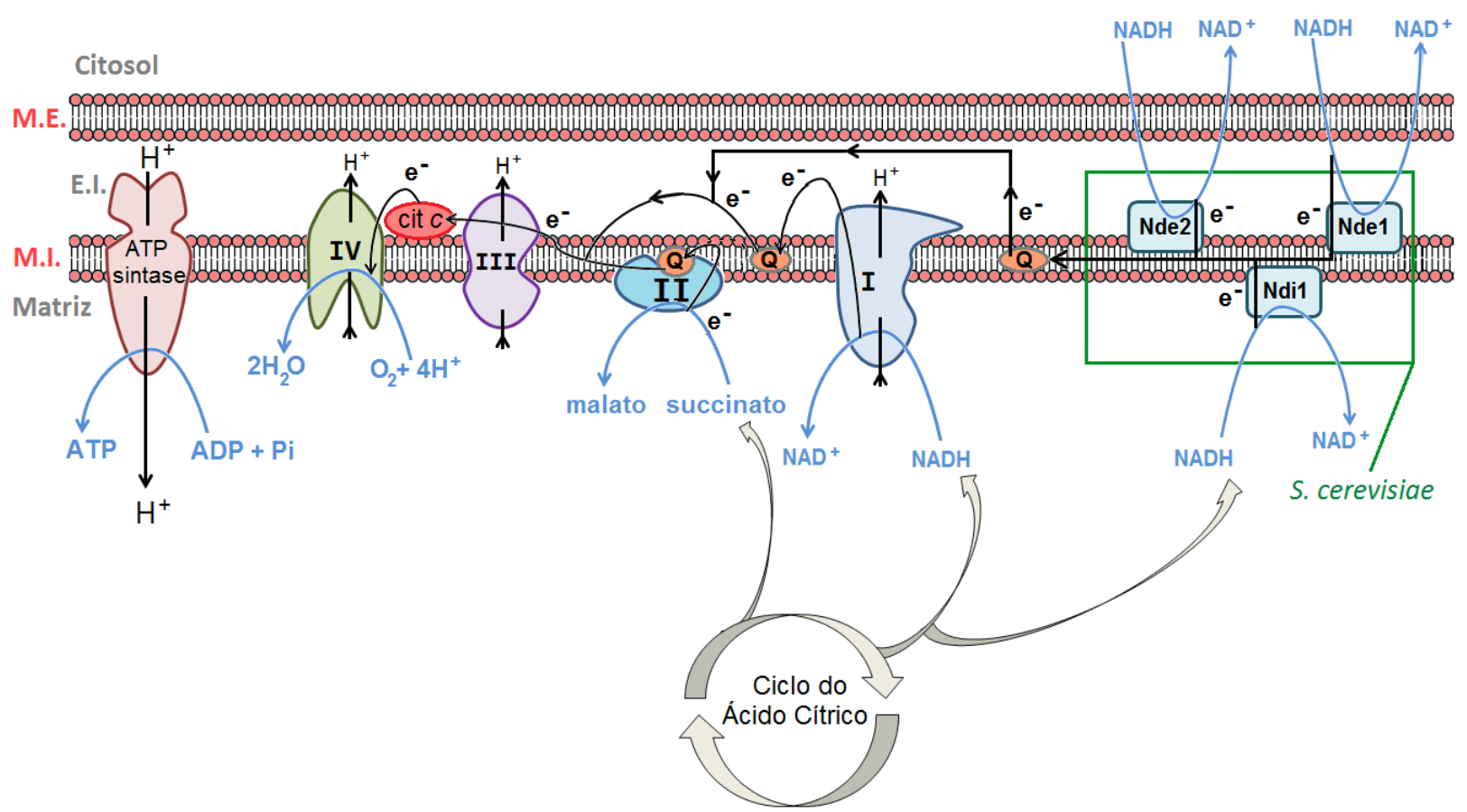

Diferentemente da maioria dos eucariotos, $S$. cerevisiae não possui as enzimas NADH desidrogenases organizadas no grande complexo I, como destacado em verde.

M.E., membrana externa; E.I., espaço intermembranar; M.I., membrana interna; Ndi1, NADH desidrogenase interna; Nde1, NADH desidrogenase externa 1; Nde2, NADH desidrogenase externa 2; I, complexo I; II, complexo II; III, complexo III; IV, complexo IV; Q, ubiquinona; cit $c$, citocromo $c$; $\mathrm{e}^{-}$, elétron, $\mathrm{H}^{+}$, próton.

Como discutido e destacado na figura acima, a mitocôndria de $S$. cerevisiae apresenta uma peculiaridade em relação aos outros eucariotos: essa levedura não apresenta um complexo I funcional constituído de várias subunidades, mas, sim, três NADH desidrogenases insensíveis a rotenona, localizadas na membrana interna mitocondrial que, como o complexo I, executam o acoplamento da oxidação do NADH com a redução da ubiquinona. No entanto, não transferem prótons para o espaço intermembranas e, portanto, não estão acopladas à geração da força próton-motriz necessária para a fosforilação do ADP em ATP (BAKKER et al., 2001).

Durante a fosforilação oxidativa, frequentemente, espécies reativas de oxigênio (ROS) são geradas pela redução incompleta do $\mathrm{O}_{2}$ : quando ocorre vazamento de elétrons derivados do $\mathrm{NADH}$ e do $\mathrm{FADH}_{2}$, eles podem interagir diretamente com o $\mathrm{O}_{2}$ formando o radical 
superóxido, principal precursor de outras ROS (MURPHY, 2009). Os complexos respiratórios I e III são apontados como os principais centros de geração de ROS (SUN; TRUMPOWER, 2003; TURRENS, 2003). Em S. cerevisiae, as NADH desidrogenases externas também estão envolvidas nesse processo (FANG; BEATTIE, 2003).

\subsubsection{Mitocôndria na doença de Parkinson}

Crescentes evidências sugerem um papel importante das mitocôndrias, responsáveis pela respiração celular e pela produção de energia na forma de ATP, no desenvolvimento de PD. As membranas mitocondriais são compostas, predominantemente, por cardiolipina, um fosfolipídio aniônico, um dos alvos preferenciais de $\alpha$-sin (PRANKE et al., 2011), o que explicaria sua detecção em frações mitocondriais (LI et al., 2007).

Como discutido, mutações na proteína $\alpha$-sin e aumento em seus níveis celulares são os maiores responsáveis pela oligomerização, formação de fibrilas e agregação em corpos de Lewy, fenômeno característico de PD. Recentemente, Sekigawa e colaboradores (2013) mostraram que, em sinucleinopatias, ocorre aprisionamento de mitocôndrias por $\alpha$-sin, levando à disfunção mitocondrial e falhas no controle de qualidade bioenergético. Esses resultados vão de encontro à observação de que os corpos de Lewy estão relacionados a um aumento na produção de ROS pela mitocôndria (JUNN; MOURADIAN, 2002), fenômeno observado por Xu e colaboradores (2002) em neurônios dopaminérgicos. Portanto, pode-se dizer que o estresse oxidativo causado por ROS é um componente importante no desenvolvimento da doença.

Como revisto por Kowaltowski e colaboradores (2009), a mitocôndria pode ser considerada o maior sítio gerador de ROS no interior das células, devido ao seu elevado metabolismo oxidativo. As principais espécies formadas são radicais superóxido $\left(\mathrm{O}_{2}{ }^{\circ}\right)$ e hidroxila $\left(\mathrm{OH}^{*}\right)$, o peróxido de hidrogênio $\left(\mathrm{H}_{2} \mathrm{O}_{2}\right)$ e o oxigênio singlete.

A produção exagerada e acúmulo de ROS levam ao estresse oxidativo, situação na qual as biomoléculas, como lipídios, proteínas e DNA, são extensivamente oxidados e danificados, perdendo suas propriedades biológicas. A mitocôndria é particularmente susceptível a esse tipo de dano, já que nela ocorre a maior parte da geração de ROS. Quando há dano no DNA mitocondrial, podem ocorrer mutações em genes da $\mathrm{CTe}^{-}$, diminuindo a eficiência da respiração celular e da fosforilação oxidativa, o que, consequentemente, torna $\mathrm{o} \mathrm{O}_{2}$ mais disponível na organela e aumenta a produção de ROS, que irão danificar ainda mais o DNA 
mitocondrial, num processo de reatroalimentação positiva (TRACHOOTHAM; ALEXANDRE; HUANG, 2009), que resulta em disfunção mitocondrial generalizada.

Diversos estudos mostram uma correlação entre níveis elevados de $\alpha$-sin e disfunção mitocondrial. Elkon e colaboradores (2002) mostraram que há uma interação muito forte entre $\alpha$-sin (normal e A53T) e complexo IV (COX), sendo que camundongos expressando formas mutantes de $\alpha$-sin humana exibiram redução significativa da atividade de COX (MARTIN et al., 2006). Devi e colaboradores (2008) mostraram que, em culturas neuronais embrionárias humanas, o acúmulo progressivo de $\alpha$-sin inibe o complexo I (NADH - ubiquinona oxidorredutase) e aumenta o estresse oxidativo. Haas e colaboradores (1995) mostraram, nos estágios iniciais de PD, que há diminuição na atividade dos complexos I e II/III em pacientes não tratados. Ainda, a agregação de $\alpha$-sin estaria relacionada a alterações oxidativas dos componentes mitocondriais e à liberação de citocromo $c$, induzindo apoptose em cérebros de rato (PARIHAR et al., 2008). Recentemente, Xie e Chung (2012) mostraram que a expressão de $\alpha$-sin mutante altera a morfologia e dinâmica mitocondriais, já que essa proteína inibe fusões, levando à fragmentação mitocondrial (KAMP et al., 2010), o que seria ainda mais agravado pelo aprisionamento das mitocôndrias em corpos de Lewy (SEKIGAWA et al., 2013). As alterações morfológicas causam uma queda na fosforilação oxidativa e no consumo de oxigênio e, em culturas de neurônios, fragmentação mitocondrial que precede neurodegeneração (NAKAMURA et al., 2011). Como os neurônios dopaminérgicos são intrinsecamente suscetíveis a ROS, o aumento do estresse oxidativo a partir de disfunção mitocondrial é muito danoso, causando a perda dessa população neuronal e agravando os sintomas da doença de Parkinson (HWANG, 2013). Assim, o equilíbrio entre produção e degradação de ROS pelas defesas antioxidantes é essencial para a viabilidade celular.

\subsection{Antioxidantes naturais}

Antioxidantes são moléculas que inibem a oxidação de outras, impedindo que as oxidações se propaguem através de sua inibição ou da degradação de intermediários radicalares reativos. Antioxidantes naturais podem ser obtidos na dieta, como a vitamina $\mathrm{E}(\alpha-$ tocoferol) e a vitamina $\mathrm{C}$ (ascorbato) presentes em vegetais, ou podem ser sintetizados pelo organismo, como a glutationa, a coenzima Q e a melatonina. Existem, também, enzimas que catalisam a degradação de ROS, como a superóxido dismutase (SOD), que prove a dismutação do radical $\mathrm{O}_{2}{ }^{-}$em $\mathrm{H}_{2} \mathrm{O}_{2}$, e as glutationa peroxidase, tiorredoxina peroxidase e 
catalase, que reduzem o $\mathrm{H}_{2} \mathrm{O}_{2}$ em duas moléculas de água (peroxidase) ou em água e $\mathrm{O}_{2}$ (catalase) (HERRERO et al., 2008).

As defesas antioxidantes são reguladas em diferentes níveis. Obviamente, o estado redox da célula é o fator primário que irá regular tanto a expressão gênica quanto a atividade das enzimas (PAHL; BAEUERLE, 1994). Como revisto por Rodriguez e colaboradoradores (2004), existem outros fatores que influenciam a atividade das enzimas antioxidantes, como diferenciação celular, envelhecimento, inflamações e regulação hormonal. Quando os níveis de antioxidantes são insuficientes para neutralizar os efeitos de ROS, também haverá dano oxidativo excessivo que poderá danificar significativamente as células e, inclusive, mata-la. Assim, em diversas doenças com forte componente oxidativo, buscam-se terapias para reposição das defesas antioxidantes das células para diminuir seus sintomas.

O efeito antioxidante deve-se pela degradação de ROS ou pela quelação de metais de transição envolvidos na geração de ROS a partir de $\mathrm{H}_{2} \mathrm{O}_{2}$ através de reações de Fenton. No caso da via de redução do oxigênio, a primeira etapa é a dismutação de $\mathrm{O}_{2}{ }^{\circ-} \mathrm{em} \mathrm{H}_{2} \mathrm{O}_{2}$ e em $\mathrm{O}_{2}$, catalisada pela CuZnSOD citoplasmática e pela MnSOD da matriz mitocondrial. Apesar de $\mathrm{H}_{2} \mathrm{O}_{2}$ não ser um radical livre, em contato com metais de transição, como o íon ferroso $\left(\mathrm{Fe}^{2+}\right)$, ele é rapidamente convertido no radical hidroxila, altamente reativo, via reação de Fenton (GOLDSTEIN; MEYERSTEIN; CZAPSKI, 1993). Portanto, $\mathrm{H}_{2} \mathrm{O}_{2}$ deve ser rapidamente degradado por peroxidases e catalases (MATES, 2000), ou os íons metálicos devem ser quelados eficientemente por proteínas, como transferrina e ferritina (revisto por IMLAY, 2003).

Geralmente, esses processos ocorrem através de ciclos de oxidação e redução dos próprios antioxidantes (ciclos redox): elas se oxidam para inativarem ROS, e, depois, devem ser reduzidas para serem recicladas, conservando suas propriedades. No entanto, substâncias que possuem um ciclo redox, como a coenzima $\mathrm{Q}$, podem atuar como moléculas próoxidantes condicionais, quando há maior produção de suas formas oxidadas, situação em que contribuiriam, paradoxalmente, para um aumento no estresse oxidativo, fenômeno comumente observado com o envelhecimento (SOHAL; MOCKETT; ORR, 2002). Alguns antioxidantes, como a melatonina, são conhecidos como antioxidantes terminais: como não possuem ciclo redox, uma vez oxidados, não podem ser novamente reduzidos, sendo, então, degradados (TAN et al., 2000). Dessa forma, a escolha do antioxidante para uma possível terapia de doenças neurodegenerativas deve ser feita de maneira meticulosa, pois há o risco de o estresse oxidativo ser agravado. 
1.4.1 Melatonina: uma molécula, múltiplas funções

A formação de ROS ocorre naturalmente nas mitocôndrias, mas pode ser agravada em certas doenças, ocasionando morte celular. A melhora da atividade respiratória mitocondrial, bem como a ação de substâncias antioxidantes, pode ser essencial nos neurônios acometidos pelos primeiros sintomas intracelulares de degeneração funcional, típicos das doenças neurodegenerativas, como PD. Dentre os antioxidantes naturais, destaca-se aqui a melatonina (MLT), "uma molécula filogeneticamente antiga, presente na maioria das espécies, inclusive organismos unicelulares", produzida em mamíferos pela glândula pineal no escuro (MARKUS; BARBOSA; FERREIRA, 2003) e, também, em outros tecidos extrapineais, como a retina (IUVONE; BESHARSE, 1983), gônadas (ITOH et al., 1999; TUMES; PEDRAZA; VALLADARES, 1996), glândula Harderiana (MENÉNDEZ-PELÁEZ et al., 1987), medula óssea (CONTI et al., 2000), epitélio do trato respiratório (KVETNOY, 1999), intestinos (HUETHER et al., 1992), dentre outros. É uma molécula anfifílica, capaz de atingir todos os compartimentos do organismo, atravessando membranas celulares e organelas, inclusive a mitocôndria.

Como revisto por Markus e colaboradores (2003) e esquematizado na figura 1.5, a glândula pineal capta o aminoácido 5-hidroxitriptofano e o transforma em serotonina (5hidroxitriptamina), em alta concentração durante o dia. Na fase de escuro há síntese da enzima AANAT (arilalquilamina $\mathrm{N}$-acetiltransferase), enzima-chave que metaboliza a serotonina em $\mathrm{N}$-acetilserotonina. Parte deste produto lipossolúvel é lançada na circulação, mas parte é metabolizada pela enzima hidroxiindol-O-metil-transferase (HIOMT) em MLT. 
Figura 1.5 - Representação esquemática da via biossintética da melatonina na glândula pineal humana.

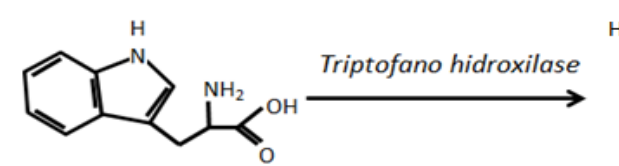

Triptofano

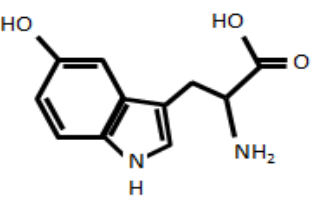

5-HTP

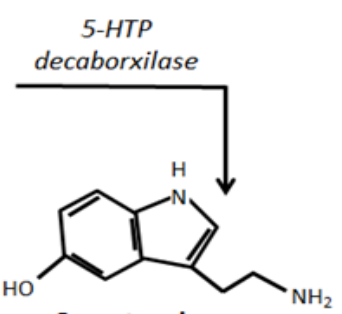

Serotonina

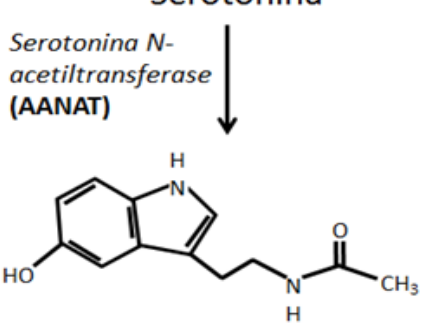

$\mathrm{N}$-acetil-Serotonina

Humanos e leveduras compartilham parte da via, exceto que leveduras não produzem melatonina por não possuírem a enzima hidroxiindole-O-metiltransferase (HIOMT). As enzimas utilizadas nas clonagens deste trabalho (AANAT e HIOMT) estão indicadas em negrito.

Fonte: Adaptado de Koch et al. (2009).

Primeiro hormônio isolado da glândula pineal mamífera (ALBERTI, 1958), logo se descobriu que MLT é indutor de sono (MARCZYNSKI, 1964) transdutor do ritmo circadiano em vertebrados (PERREAU-LENZ et al., 2003). Adicionalmente, no início dos anos 1990, descreveram-se funções antioxidantes para MLT na remoção de radical hidroxila (TAN et al., 1993). Posteriormente, verificou-se que MLT, além de degradar hidroxila, também está envolvida na remoção de $\mathrm{H}_{2} \mathrm{O}_{2}$ e oxigênio singlete e na detoxificação de espécies reativas de nitrogênio (revisto por Reiter et al., 2003).

Além de efeitos diretos, MLT possui ações indiretas, como na regulação da transcrição de genes de enzimas antioxidantes. As enzimas antioxidantes apresentam um ritmo circadiano tanto para sua atividade como para a expressão gênica. Em animais constantemente expostos à luz, o ritmo endógeno de melatonina é interrompido e, com isso, o pico noturno da atividade de SOD foi abolido (ALBARRÁN et al., 2001). A administração exógena de MLT aumenta os níveis de RNA mensageiro de SOD nas glândulas Harderianas e no córtex cerebral de hamster (ANTOLÍN et al., 1996; KOTLER et al., 1998). Mayo e colaboradores (2002) também mostraram que MLT aumentava a meia-vida dessas enzimas.

Essas propriedades antioxidantes são importantes para o SNC, um tecido altamente susceptível ao estresse oxidativo. $\mathrm{O}$ alto consumo de $\mathrm{O}_{2}$ requerido para as funções cerebrais 
inevitavelmente aumenta a geração de radicais livres pela mitocôndria, que poderão danificar biomoléculas. Alguns autores mostraram que a peroxidação lipídica no tecido nervoso é inibida por MLT (REITER, 1998; REITER et al., 2005). Como revisto por Srinivasan e colaboradores (2006), geralmente há uma baixa atividade de enzimas antioxidantes relativamente ao seu consumo de $\mathrm{O}_{2}$. MLT é conhecida por aumentar a atividade enzimática, e, quando está altamente disponível no cérebro, aumenta significativamente a atividade de glutationa peroxidase (HARDELAND, 2005).

Estudos dos efeitos da MLT sobre a mitocôndria revelam ação protetora. Yuan e Pang (1991) mostraram que MLT se liga a membranas mitocondriais. Além de sua ação antioxidante direta, MLT atenua a peroxidação lipídica, prevenindo danos oxidativos ao DNA e às proteínas. Além disso, MLT é conhecida por melhorar o estado redox mitocondrial: em ratos submetidos ao estresse oxidativo após tratamento com ácido caínico, injeção intraperitonial de MLT diminui a peroxidação lipídica e restaura parcialmente os níveis de coenzima $\mathrm{Q}_{10}$ em frações mitocondriais e em homogenatos do hipocampo, sugerindo um papel protetor contra patologias do SNC em que o estresse oxidativo contribui para disfunção mitocondrial (YALCIN et al., 2004). MLT também normaliza os níveis de glutationa reduzida em relação à forma oxidada, pois aumenta os níveis da enzima glutationa redutase, responsável por restaurar o pool de glutationa reduzida mitocondrial (ACUÑACASTROVIEJO et al., 2012). Adicionalmente, Okatani e colaboradores (2003) mostraram que a administração oral de MLT aumenta a atividade da enzima antioxidante glutationa peroxidase em camundongos modelo para senescência acelerada, contribuindo para diminuição da peroxidação lipídica mitocondrial. A administração de melatonina também aumentou a atividade dos complexos respiratórios I e IV em partículas submitocondriais de cérebro e figado (MARTIN et al., 2000; OKATANI et al., 2003) e, também, a produção de ATP (MARTIN et al., 2002), efeito também observado no envelhecimento de camundongos (OKATANI; WAKATSUKI; REITER, 2002), mantendo o metabolismo bioenergético e o consumo de oxigênio, necessários para o funcionamento do tecido nervoso.

A quantidade de MLT produzida pela pineal de mamíferos tende a diminuir com o envelhecimento do animal. Em humanos idosos, há um decréscimo no pico noturno desse hormônio (SACK et al., 1986), resultando em distúrbios do sono (YOUNGSTEDT et al., 2001). Essa redução relacionada ao envelhecimento deve-se a diferentes causas, como a deterioração do SNC ou da transmissão neuronal a partir da glândula pineal ou, até mesmo, devido à calcificação da pineal (SCHMID, 1993). 
Em diversas doenças neurodegenrativas, a diminuição da secreção de MLT é ainda mais exacerbada que a normalmente observada no envelhecimento, como na doença de Alzheimer (AD, do inglês Alzheimer's disease) e outros tipos de demência senil. Em muitos pacientes, o ritmo de secreção de MLT foi completamente abolido como resultado da degeneração do SNC e de suas conexões (SRINIVASAN et al., 2005). Em AD, há um quadro atípico de estresse oxidativo e de processos inflamatórios que, presume-se, contribuiria para a progressão da doença. Nessa situação, a depleção dos níveis de MLT seria preocupante devido à sua ação antioxidante e anti-inflamatória (SRINIVASAN et al., 2006).

De fato, em camundongos transgênicos modelos de $\mathrm{AD}$, o tratamento com MLT exógena, no início da vida, levou a reduções no estresse oxidativo e na agregação amiloide, e, também, aumentou a sobrevivência (MATSUBARA et al., 2003). Reduções na apoptose de neurônios também foram observadas, o que diminuiria os sintomas cognitivos e comportamentais de AD (FENG et al., 2004). Estudos in vitro mostram que MLT diminui a formação de fibrilas amiloides (POEGGELER et al., 2001). No entanto, nenhum benefício significativo foi observado em estágios tardios de AD (QUINN et al., 2004), o que é importante no tratamento de humanos, que geralmente são diagnosticados quando a doença já está progredindo.

As doenças neurodegenerativas como AD e PD apresentam características similares, como estresse oxidativo e um constante estado pró-inflamatório no SNC. Como a mitocôndria é fonte primária de ROS e, também, seu alvo, e como há disfunção mitocondrial nessas doenças, o tratamento com MLT pode ser promissor nessas situações devido a suas propriedades antioxidantes. É importante salientar que esse tratamento deve começar nos estágios iniciais da neuropatologia e ser mantido, pois se devem evitar ao máximo as lesões no SNC características das doenças.

\subsection{Saccharomyces cerevisiae como modelo para o estudo de doenças}

Saccharomyces cerevisiae é um fungo unicelular leveduriforme que, acredita-se, foi primeiramente isolado do malte usado na fabricação de cerveja. $\mathrm{O}$ nome vem do grego latinizado: saccharo significa açúcar, myces, fungo, e cerevisiae, da cerveja. É um organismo muito útil para o homem na fabricação de vinho, cerveja e pães, estando entre os organismos domesticados mais antigos (FELDMANN, 2010). Essa levedura é encontrada naturalmente nas cascas de uvas e é dispersa por alguns tipos de vespas, processo importante para manter a diversidade de leveduras selvagens (STEFANINI et al., 2012). 
Nos anos 1950, S. cerevisiae começou a ganhar importância como modelo de estudo biológico com experimentos de recombinação do loci adenina, realizados por Herschel Roman (FELDMANN, 2010). Um organismo modelo é um modelo in vivo estudado extensivamente para entender um fenômeno biológico de interesse, principalmente se esse fenômeno ocorrer em humanos e a experimentação humana não for possível. Segundo Feldmann (2010), S. cerevisiae se enquadra nessa categoria por apresentar muitas vantagens:

a. É um organismo unicelular capaz de crescer em meio de cultura definido, o que possibilita maior controle das interferências químicas e físicas ambientais;

b. O cultivo de leveduras é barato, depende de pequeno espaço para crescimento, que pode ser modulado em diferentes temperaturas;

c. Possui tempo de geração pequeno e um ciclo de vida curto, com alternância de gerações, facilitando estudos e manipulações genéticos;

d. As células se dividem e a progênie pode ser separada por micromanipulação.

e. Pode ser mantido e estudado em seu estado haploide, possibilitando estudos de recombinação homóloga.

Ainda, o pequeno tamanho de seu genoma possibilitou o primeiro sequenciamento genético completo (GOFFEAU et al., 1996), o que permitiu um maior controle de estudos moleculares no organismo. O DNA nuclear, de 12068 kilobases, está organizado em 16 cromossomos, com cerca de 6000 genes que codificariam proteínas em potencial. Estudos genéticos posteriores revelaram alto grau de conservação ou de similaridade entre os produtos gênicos de leveduras e de outros eucariotos, o que mostrou que as leveduras são excelentes modelos para a análise de genes de outros organismos.

A levedura é, também, excelente modelo para estudos mitocondriais, pois é um organismo aeróbio facultativo, o que permite isolar mutantes respiratórios em meios apropriados (FOURY; KUCEJ, 2001). Em 1964, Schatz relatou, pela primeira vez, a existência de DNA dentro das mitocôndrias. A maioria dos genes mitocondriais de $S$. cerevisiae é altamente conservada nos outros eucariotos, permitindo estudos fisiológicos de proteínas mitocondriais (RABILLOUD et al., 1998).

Desde a década de 1940, estudos dessa natureza já são realizados nesse organismo: Ephrussi e colaboradores, utilizando o agente mutagênico acriflavina, descobriram colônias menores (petites) que eram mutantes respiratórios e que só poderiam crescer em fontes de carbono fermentáveis. Por meio de análises genéticas, descobriram que a mutação não apresentava segregação mendeliana e puderam concluir que um fator $\rho$, não cromossomal, 
herdável, era responsável pela morfogênese mitocondrial (EPHRUSSI et al., 1949). As colônias petites possuem grandes deleções no DNA mitocondrial (MONOULOU; JOKOB; SLONIMSKI, 1966), implicando em deficiência respiratória.

As observações de que petites possuíam deleções no DNA mitocondrial indicaram a importância desse genoma para a respiração. Foury e colaboradores (1998) verificaram que o DNA mitocondrial de S. cerevisiae possui cerca de 86000 pares de base com informação para 2 rRNA, 24 tRNA e 30 proteínas estruturais; cerca de 1/3 do restante está envolvido em funções de montagem das subunidades dos complexos respiratórios. Hodges e colaboradores (1999) observaram que a maioria das proteínas mitocondriais é codificada pelo genoma nuclear, traduzidas e modificadas no citoplasma para então serem importadas pela mitocôndria.

Aerobiose facultativa e a grande similaridade entre mitocôndrias de leveduras e humanos vem possibilitando estudos utilizando S. cerevisiae como modelo para identificar genes nucleares humanos envolvidos em doenças mitocondriais (BARRIENTOS, 2003). Como discutido anteriormente, disfunções mitocondriais estão frequentemente associadas a doenças neurodegenerativas. Assim, S. cerevisiae também tem sido utilizada como modelo no estudo do efeito de mutações genéticas relacionadas a diversos distúrbios neurológicos e encefalomiopatias, bem como para as terapias associadas. Como S. cerevisiae não possui proteínas homólogas a $\alpha$-sin, diversos estudos vêm usando essa levedura para melhor entender os efeitos fisiológicos e toxicológicos da agregação dessa proteína, característicos de PD (COOPER et al., 2006; DIXON et al., 2005; KHURANA; LINDQUIST, 2010; OUTEIRO; LINDQUIST, 2003). No estudo dos mecanismos de ação da melatonina, Ganguly e colaboradores (2001) descreveram uma provável enzima AANAT (arilalquilamina Nacetiltransferase) em $S$. cerevisiae (scAANAT), codificada pelo gene PAAl, que possui a atividade catalítica da AANAT de vertebrados. Todavia, a enzima subsequente na via biossintética de melatonina, a hidroxi-indol-O-metil-transferase (HIOMT), está ausente em $S$. cerevisiae.

Neste trabalho, realizamos a expressão heteróloga de HIOMT humana em leveduras a fim de estudar as consequências da presença de melatonina em $S$. cerevisiae e, particularmente, seus possíveis efeitos antioxidantes sobre a mitocôndria. Considerando, os efeitos citotóxicos da expressão de $\alpha$-sin em leveduras, como alteração do tráfego vesicular, acúmulo de gotas lipídicas em seu citoplasma, diminuição nos níveis de NADPH e de glutationa e aumento da produção de ROS (SERE et al., 2010), propomos que a 
suplementação farmacológica bem como a produção de melatonina em levedura e seu consequente efeito antioxidante podem aliviar os efeitos do acúmulo de ROS em células parkinsonianas o que, futuramente, pode auxiliar na compreensão do desenvolvimento da doença de Parkinson em mamíferos. 


\section{OBJETIVO GERAL}

Estudar os efeitos antioxidantes da melatonina na recuperação de $S$. cerevisiae expressando o gene $S N C A$.

\subsection{Objetivos específicos}

1. Construir linhagens parentais de S. cerevisiae expressando SNCA em diversos níveis e tipos de vetores;

2. Produzir melatonina em leveduras via superexpressão do gene $P A A 1$, que codifica a enzima scAANAT, e expressão heteróloga do gene ASMT humano, o qual codifica a enzima HIOMT;

3. Caracterizar os efeitos celulares da presença de melatonina e/ou SNCA:

a. Avaliar o crescimento das linhagens sob diferentes tipos de estresse;

b. Analisar a longevidade;

c. Avaliar a função mitocondrial, por medida de atividade de complexos respiratórios e taxa de consumo de oxigênio. 


\section{MATERIAIS E MÉTODOS}

\subsection{Cepas de $S$. cerevisiae}

Tabela 3.1 - Linhagens de S. cerevisiae, com seus respectivos genótipos, utilizadas neste trabalho.

\begin{tabular}{|c|c|c|}
\hline Linhagem & Genótipo & Referência \\
\hline W303-1B & $\begin{array}{l}\text { MAT } \alpha \text { ade2-1, trp1-1, his3-115, leu2-3,112 ura3-1 } \rho \\
+, \text { can }^{R}\end{array}$ & $\begin{array}{l}\text { Rothstein, } \\
\text { Columbia } \\
\text { University }\end{array}$ \\
\hline W303-1A & $\begin{array}{l}\text { MAT a ade2-1, trp1-1, his3-115, leu2-3,112 ura3-1 } \rho \\
+, \text { can }^{R}\end{array}$ & $\begin{array}{l}\text { Rothstein, } \\
\text { Columbia } \\
\text { University }\end{array}$ \\
\hline $\begin{array}{l}\text { W303-1B } \\
\text { PD1 }\end{array}$ & $\begin{array}{l}\text { MAT } \alpha \text { ade } 2-1, \text { trp } 1-1, \text { his3-115, leu2-3,112 ura3-1 } \rho \\
+, \text { can } R, \mathrm{pEG}(\mathrm{KG}) \text { SNCA, URA3, leu2d }\end{array}$ & Este trabalho \\
\hline $\begin{array}{l}\text { W303-1B } \\
\text { MLT10 }\end{array}$ & $\begin{array}{l}\text { MAT } \alpha \text { ade2-1, trp1-1, his3-115, leu2-3,112 ura3-1 } \rho \\
+, \text { can }^{R, G A L 10-A S M T, ~ G A L 10-A A N A T, ~ T R P-1 ~}\end{array}$ & Este trabalho \\
\hline $\begin{array}{l}\text { W303-1B } \\
\text { PD1-MLT10 }\end{array}$ & $\begin{array}{l}\text { MAT } \alpha \text { ade2-1, trp1-1, his3-115, leu2-3,112 ura3-1 } \rho \\
+, \quad \text { can } R, \text { pEG(KG)SNCA, URA3, leu2d, GAL10- } \\
\text { ASMT, GAL10-AANAT,TRP1 }\end{array}$ & Este trabalho \\
\hline $\begin{array}{l}\text { W303-1A } \\
\text { PD1 }\end{array}$ & $\begin{array}{l}\text { MATa ade2-1, trp1-1, his3-115, leu2-3,112 ura3-1 } \rho \\
+, \text { can } R, \mathrm{pEG}(\mathrm{KG}) \text { SNCA, URA3, leu } 2 d\end{array}$ & Este trabalho \\
\hline $\begin{array}{l}\text { W303-1A } \\
\text { PD2 }\end{array}$ & $\begin{array}{l}\text { MATa ade2-1, trp1-1, his3-115, leu2-3,112 ura3-1 } \rho \\
+, \text { can } R, \text { GAL10-SNCA, LEU2 }\end{array}$ & Este trabalho \\
\hline $\begin{array}{l}\text { W303-1A } \\
\text { PD3 }\end{array}$ & $\begin{array}{l}\text { MATa ade2-1, trp1-1, his3-115, leu2-3,112 ura3-1 } \rho \\
+, \text { can } R, \text { GPD1-SNCA, LEU2 }\end{array}$ & Este trabalho \\
\hline $\begin{array}{l}\text { W303-1A } \\
\text { PD4 }\end{array}$ & $\begin{array}{l}\text { MATa ade2-1, trp1-1, his3-115, leu2-3,112 ura3-1 } \rho \\
+, \text { can } R, T E F-S N C A, \text { LEU2 }\end{array}$ & Este trabalho \\
\hline $\begin{array}{l}\text { W303-1A } \\
\text { MLT10 }\end{array}$ & $\begin{array}{l}\text { MATa ade2-1, trp1-1, his3-115, leu2-3,112 ura3-1 } \rho \\
+, \text { can } R, \text { GAL10-ASMT, GAL10-AANAT, TRP-1 }\end{array}$ & Este trabalho \\
\hline $\begin{array}{l}\text { W303-1A } \\
\text { PD1-MLT10 }\end{array}$ & $\begin{array}{l}\text { MATa ade2-1, trpl-1, his3-115, leu2-3,112 ura3-1 } \rho \\
+, \quad \text { can }{ }^{2}, \mathrm{pEG}(\mathrm{KG}) \text { SNCA, URA3, leu2d, GAL10- } \\
\text { ASMT, GAL10-AANAT, TRP-1 }\end{array}$ & Este trabalho \\
\hline
\end{tabular}

\subsection{Cepa de $E$. coli utilizada para construção de vetores recombinantes}

RR1: (4(gpt-proA)62, leuB6, thi-1, lacY1, hsdS ${ }_{B} 20$, rpsL20 (Str $\left.{ }^{r}\right)$, ara-14, galK2, xyl-5, mtl-1, supE44, $\operatorname{mcrB}_{B}$ ) (HANAHAN, 1983). 


\subsection{Procedimentos Gerais com $S$. cerevisiae e E. coli}

Os meios de cultura utilizados para o crescimento de leveduras e bactérias seguiram as formulações descritas anteriormente (ROSE; WINSTON; HIETER, 1990).

A transformação de E. coli com DNA exógeno e a preparação de bactérias competentes foram realizadas pelo método de $\mathrm{CaCl}_{2}$ (SAMBROOK; FRITSCH; MANIATIS; 1989). Minipreparação de DNA plasmidial foi realizada por lise alcalina (BIRNBOIM; DOLLY, 1979). Preparação de DNA plasmidial em média escala seguiu método de lise com Triton (AUSUBEL et al., 1989).

Empregou-se o método de Gietz para transformação de $S$. cerevisiae, com acetato de lítio e polietileno glicol (SCHIESTL; GIETZ, 1989). Mini preparação de DNA genômico de levedura foi realizada segundo método descrito por Holm e colaboradores (1986).

A extração de mitocôndrias de leveduras foi feita seguindo método descrito anteriormente (FAURES-RENOT et al., 1974), exceto pelo uso de zimoliase ao invés de glusulase. As leveduras cresceram por $60 \mathrm{~h}$ em meio mínimo com galactose, suplementado ou não com $10 \mu \mathrm{M}$ melatonina (Sigma). Após centrifugação e lavagem com 1,2 M sorbitol, a parede celular foi digerida $\left(37{ }^{\circ} \mathrm{C}, 120 \mathrm{~min}\right)$ com tampão de digestão ( $3 \mathrm{~mL} / \mathrm{g}$ células): $2 \mathrm{M}$ sorbitol; 0,5 M NaPi pH 7,5; 0,5 M EDTA pH 7,5; 0,1\% $\beta$-mercaptoetanol; zimoliase $20.000 \mathrm{U}$ (1 mg/mL tampão). Os esferoblastos foram suspensos em tampão STE (0,6 M sorbitol; $10 \mathrm{mM}$ Tris-Cl pH 7,5; 1 mM EDTA pH 7,5; 5 mM PMSF), utilizando o mesmo volume empregado com o tampão de digestão. A seguir, foram quebrados com agitador mecânico por 30 s no gelo e, então, centrifugados sequencialmente para precipitação das mitocôndrias, que são mantidas em tampão STE. Finalmente, as proteínas mitocondriais foram dosadas pelo método de Lowry (1951).

As medidas de atividade de complexo III (ubiquinol - citocromo $c$ oxidorredutase) de mitocôndrias isoladas (Tzagoloff et al., 1975) foram realizadas em tampão $10 \mathrm{mM}$ fosfato de potássio, pH 7,5. Medidas de atividade de complexo IV (citocromo $c$ oxidase) de

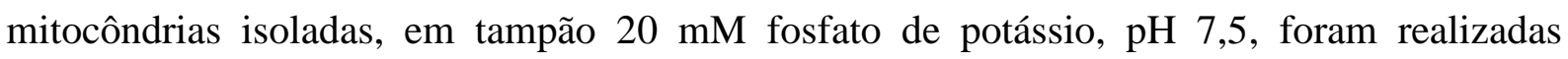
conforme descrito anteriormente (Tzagoloff et al., 1975).

O consumo de oxigênio mitocondrial $(100 \mu \mathrm{g} / \mathrm{ml}$ de proteínas mitocondriais) foi monitorado por 5 minutos em um eletrodo tipo Clarke, utilizando $1 \mu$ mol NADH como substrato, em tampão fosfato (10 mM KPi, pH 7,5). 


\subsection{Construção de vetores de expressão}

\subsubsection{Construções envolvendo o gene $S N C A$}

O vetor recombinante epissomal (pEG(KG)), contendo o gene $S N C A$, o qual codifica a proteína alfa-sinucleína (gentilmente cedido pelo Dr. David S. Gross, Louisiana State University), está esquematizado na figura 3.1. Localiza-se em múltiplas cópias no núcleo de S. cerevisiae e a expressão do gene $S N C A$ é regulada pelo promotor GAL10, cuja transcrição é induzida por galactose (DIXON et al., 2005). O vetor apresenta-se em um número moderado de cópias quando as células são cultivadas em meio mínimo com galactose, contendo leucina (aproximadamente 10 cópias por célula), mas em um número maior de cópias quando as células estão em meio mínimo na ausência de leucina (MITCHELL; MARSHALL; DESCHENES, 1993).

Figura 3.1 - Representação esquemática do vetor epissomal pEG(KG) contendo o gene SNCA.

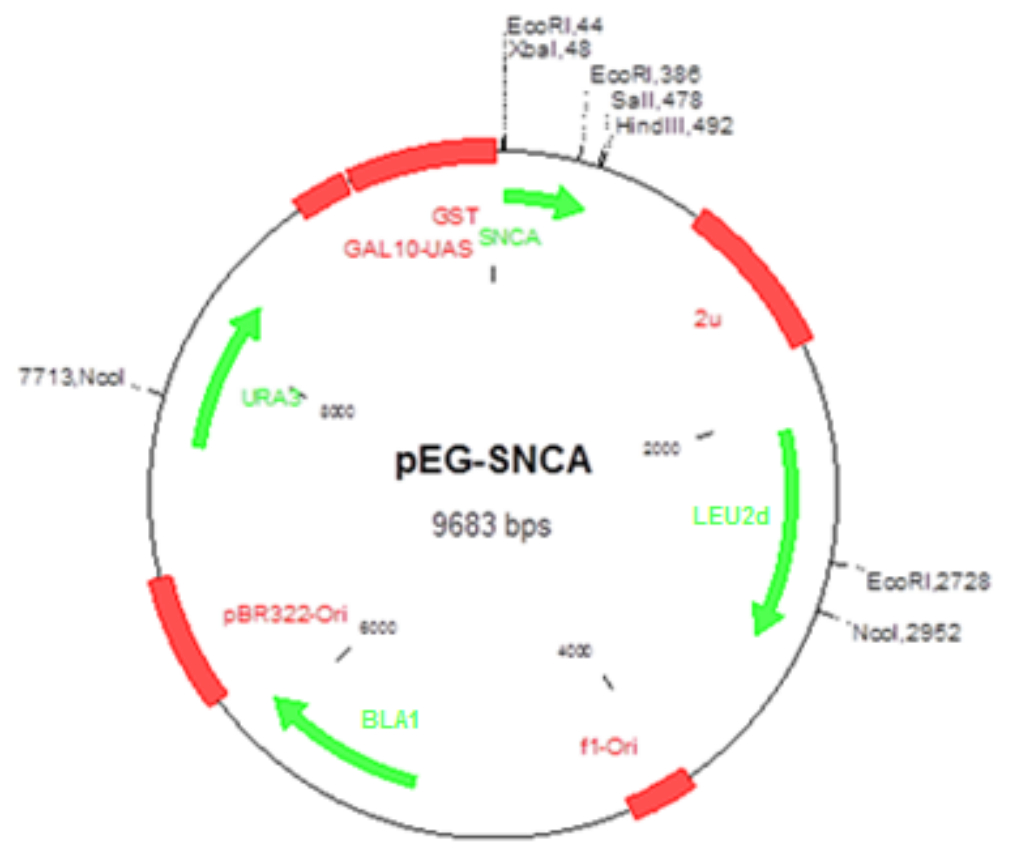

SNCA foi clonado nos sítios de XbaI e SalI, com fusão N-terminal à proteína GST. Observamse a região $2 \mu$, característica para a replicação de plasmídios epissomais, e o gene de seleção em meio mínimo sem uracila (URA3). LEU2d é uma modificação do gene $L E U 2$, a qual é importante para modular o número de cópias do vetor: na ausência de leucina, esse número é maior. Blal é um gene de seleção de bactérias em meio contendo o antibiótico ampicilina. Fonte: Adaptado de Pierce e Wendland, 2009. 
A clonagem e a sequência do gene $S N C A$ foram confirmadas previamente por digestões analíticas e por sequenciamento do plasmídio recebido. Após comprovada a identidade, oligonucleotídeos (tabela 3.2) foram desenhados para amplificar, por PCR, o gene SNCA do vetor $\mathrm{pEG}(\mathrm{KG})$, para a construção de plasmídios integrativos que modulassem seus níveis de expressão.

Tabela 3.2 - Sequência dos oligonucleotídeos utilizados para clonagem do gene SNCA em vetores integrativos de expressão.

\begin{tabular}{ccc}
\hline Oligonucleotídeo & Sequência & Posição \\
\hline SNCA-1 (Forward & 5'GGGCTGCAGCATGGATGTATTCATGAAAGGA & +1 \\
primer) & C 3' & +417 C \\
\hline $\begin{array}{c}\text { SNCA-His (Reverse } \\
\text { primer) }\end{array}$ & 5'TTTAAGCTTTTAGTGGTGGTGGTGGTGGTG & \\
\hline GGCTTCAGGTTCGTAGTC 3'
\end{tabular}

As sequências sublinhadas equivalem, respectivamente, aos sítios de clonagem PstI e HindIII. A sequência em negrito corresponde à cauda de seis resíduos de histidina (6xHis).

O amplicon, de $450 \mathrm{pb}$, foi digerido com as enzimas de restrição HindIII e PstI e inserido nos vetores integrativos YIp351-GAL10, YIp351-GPD1 e YIp351-TEF1 (ZAMPOL et al., 2010), também digeridos com as duas enzimas. Cada um dos vetores recombinantes contém um promotor diferente, para modular os níveis de $\alpha$-sin:

i) o promotor muito forte GAL10 (BASSEL; MORTIMER, 1971) tem sua expressão induzida por galactose e ativada pela proteína Gal4p, que recruta proteínas do complexo de transcrição da RNA-polimerase II (revisto em LOHR et al., 1995);

ii) o promotor forte da gliceraldeído-3-fosfato desidrogenase (GPD1) tem sua expressão regulada pela alta osmolaridade de glicerol (ALBERTYN et al., 1994);

iii) o promotor constitutivo do fator de elongação de tradução $1 \alpha$ do gene TEF2 (NAGASHIMA et al., 1986; SCHIRMAIER; PHILIPPSEN, 1984) foi utilizado para induzir a transcrição de $S N C A$ a níveis menores.

As construções resultantes estão esquematizadas, respectivamente, nas figuras 3.2, $3.3 \mathrm{e}$ 3.4 . 
Figura 3.2 - Representação esquemática do vetor recombinante pSNCA2, obtido a partir da clonagem do gene SNCA com a expressão regulada pelo promotor GAL10.

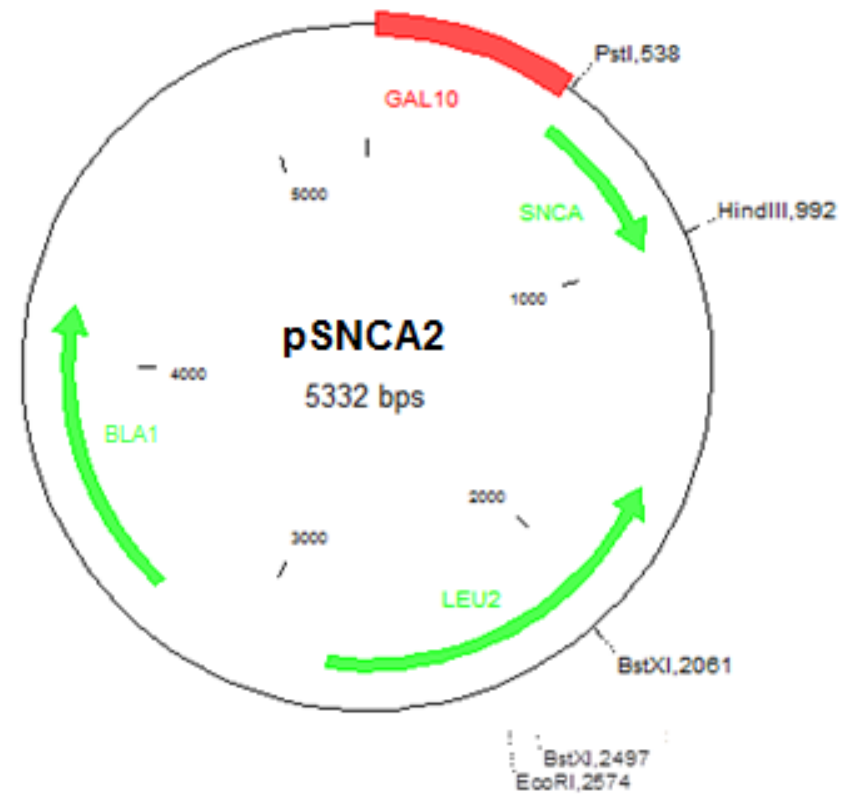

Em destaque, estão os sítios de restrição relevantes para clonagens e os genes de seleção de leveduras em meio mínimo sem leucina ( $L E U 2)$. BLA1 codifica a proteína $\beta$-lactamase, que torna as bactérias transformadas resistentes à ampicilina.

Figura 3.3 - Representação esquemática do vetor recombinante pSNCA3, obtido a partir da clonagem do gene $S N C A$ com a expressão regulada pelo promotor GPD1.

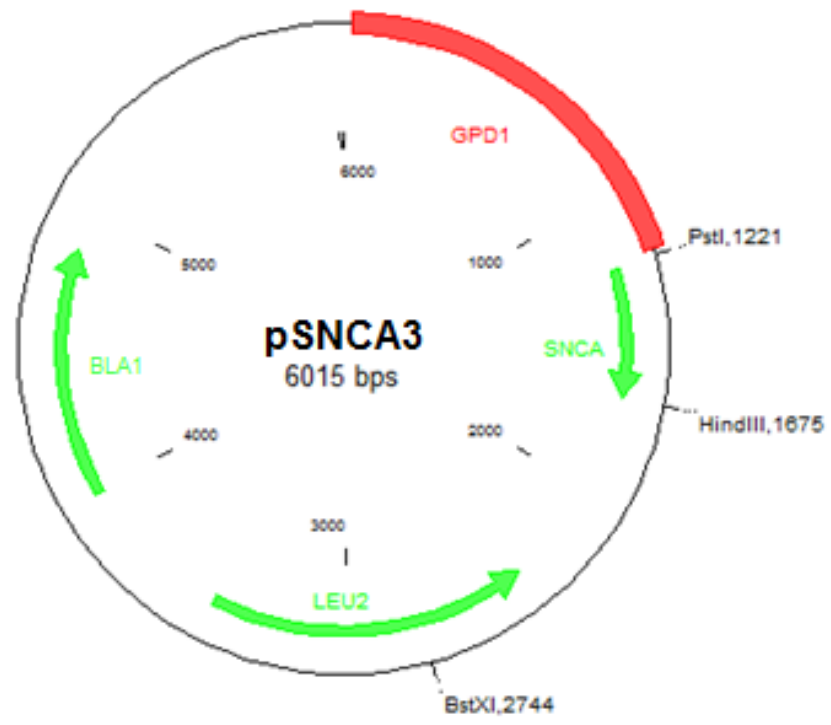

Em destaque, estão os sítios de restrição relevantes para clonagens e os genes de seleção de leveduras em meio mínimo sem leucina ( $L E U 2)$. BLA1 codifica a proteína $\beta$-lactamase, que torna as bactérias transformadas resistentes à ampicilina. 
Figura 3.4 - Representação esquemática do vetor recombinante pSNCA4, obtido a partir da clonagem do gene SNCA com a expressão regulada por TEF1.

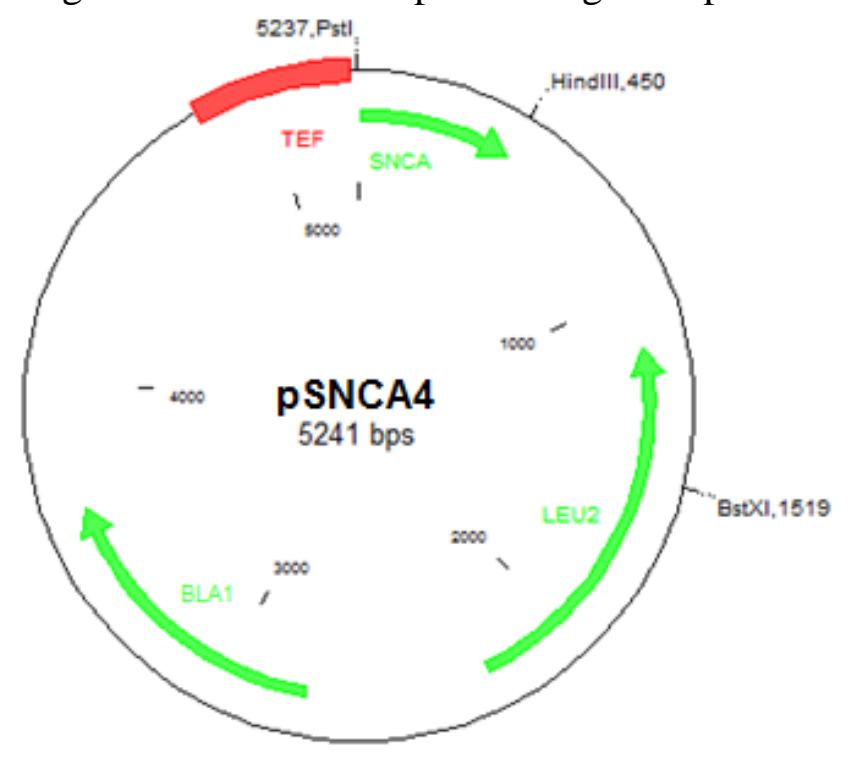

Em destaque, estão os sítios de restrição relevantes para clonagens e os genes de seleção de leveduras em meio mínimo sem leucina (LEU2). BLA1 codifica a proteína $\beta$-lactamase, que torna as bactérias transformadas resistentes à ampicilina.

\subsubsection{Construções envolvendo o gene PAAl}

Visando aumentar a expressão de enzimas da via de biossíntese da melatonina, o gene de $S$. cerevisiae PAAl (YDR071C), que codifica a enzima scAANAT (GANGULY et al., 2001), foi amplificado por PCR com os oligonucleotídeos da tabela 3.3, utilizando como molde o DNA genômico de levedura D27310B-A21.

Tabela 3.3 - Sequência dos oligonucleotídeos utilizados para clonagem do gene $P A A 1$ em vetores de expressão.

\begin{tabular}{ccc}
\hline Oligonucleotídeo & Sequência & Posição \\
\hline $\begin{array}{c}\text { GAL-AANAT (Forward } \\
\text { primer) }\end{array}$ & 5'CGGCTGCAGATGGCCTCCTCAAGTAGCACG3' & +1 \\
\hline $\begin{array}{c}\text { AANAT-cMyc (Reverse } \\
\text { primer) }\end{array}$ & 5'GGCAAGCTTTCACAGGTCCTCCTCCGAGATGAGCT & +558 C \\
\hline
\end{tabular}

As sequências sublinhadas equivalem, respectivamente, aos sítios de clonagem PstI e HindIII. A sequência em negrito corresponde à cauda c-Myc.

Um fragmento de cerca de $620 \mathrm{pb}$ foi obtido e digerido com as enzimas de restrição PstI e HindIII. Este foi clonado em fase em um vetor integrativo YIplac204 (GIETZ e SUGINO, 1988) contendo o promotor GAL10 e a marca de seleção de leveduras em meio mínimo TRP1, 
como esquematizado na figura 3.5. Verificou-se, por sequenciamento, que o gene foi inserido corretamente no vetor, em fase com a cauda c-Myc, utilizada para verificar sua expressão.

Figura 3.5 - Representação esquemática do vetor integrativo pMLT6 contendo o gene $A A N A T$ com a expressão regulada pelo promotor GAL10.

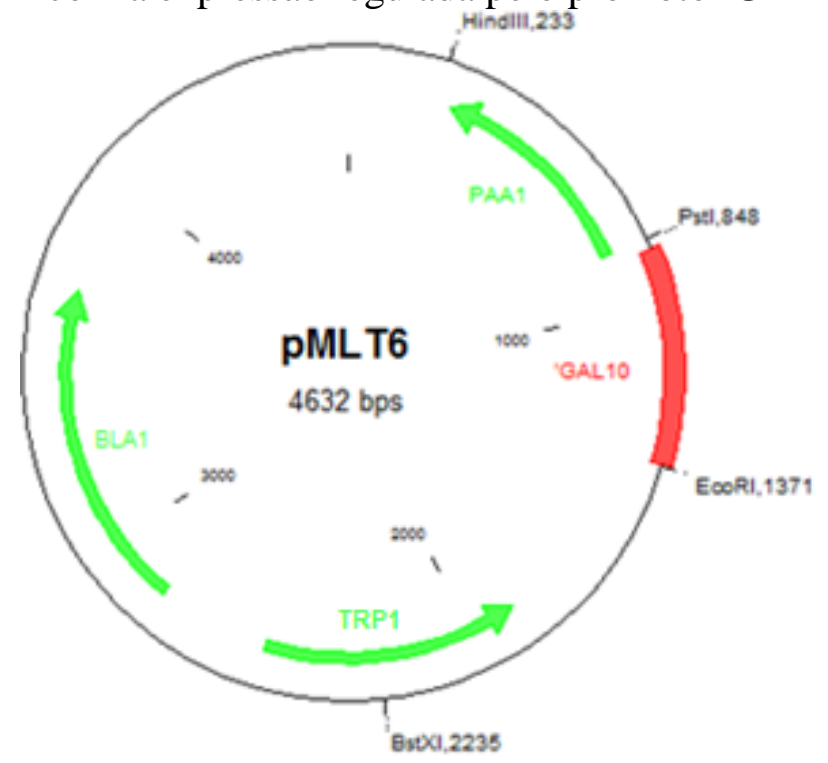

Em destaque, estão os sítios de restrição relevantes para clonagens e os gene de seleção de leveduras em meio mínimo sem triptofano (TRPl). Blal codifica a proteína $\beta$-lactamase, que torna as bactérias transformadas resistentes à ampicilina.

\subsubsection{Construções envolvendo o gene ASMT}

O gene ASMT codifica para a enzima HIOMT, a última da via biossintética da melatonina. O gene foi amplificado por PCR, utilizando como molde o cDNA do gene humano (OriGene SC320192, Ref.ID NM_004192) e os oligonucleotídeos esquematizados na tabela 3.4.

Tabela 3.4 - Sequência dos oligonucleotídeos utilizados para clonagem do gene ASMT em vetores de expressão.

\begin{tabular}{ccc}
\hline Oligonucleotídeo & Sequência & Posição \\
\hline $\begin{array}{c}\text { ASMT-1 } \text { (Forward } \\
\text { primer) }\end{array}$ & 5'GGGTCTAGAATGGGATCCTCAGAGGACCAGG 3' & +1 \\
\hline $\begin{array}{c}\text { ASMT-His (Reverse } \\
\text { primer) }\end{array}$ & $5^{\prime}$ CCCGTCGACAGTGTGGTGGTGGTGGTGGTGTAT & $+908 \mathrm{C}$ \\
\hline TTCCTGGCTAAAATGGC3' & \\
\hline
\end{tabular}

As sequências sublinhadas equivalem, respectivamente, aos sítios de clonagem XbaI e SalI. A sequência em negrito corresponde à cauda $6 x$ His. 
Um fragmento de $923 \mathrm{pb}$ foi obtido e clonado no plasmídio integrativo YIp352 (HILL et al., 1986) contendo o promotor GAL10, resultando na construção esquematizada na figura 3.6.

Figura 3.6 - Representação esquemática do vetor integrativo pASMT-1 contendo o gene $A S M T$ com a expressão regulada pelo promotor GAL10.

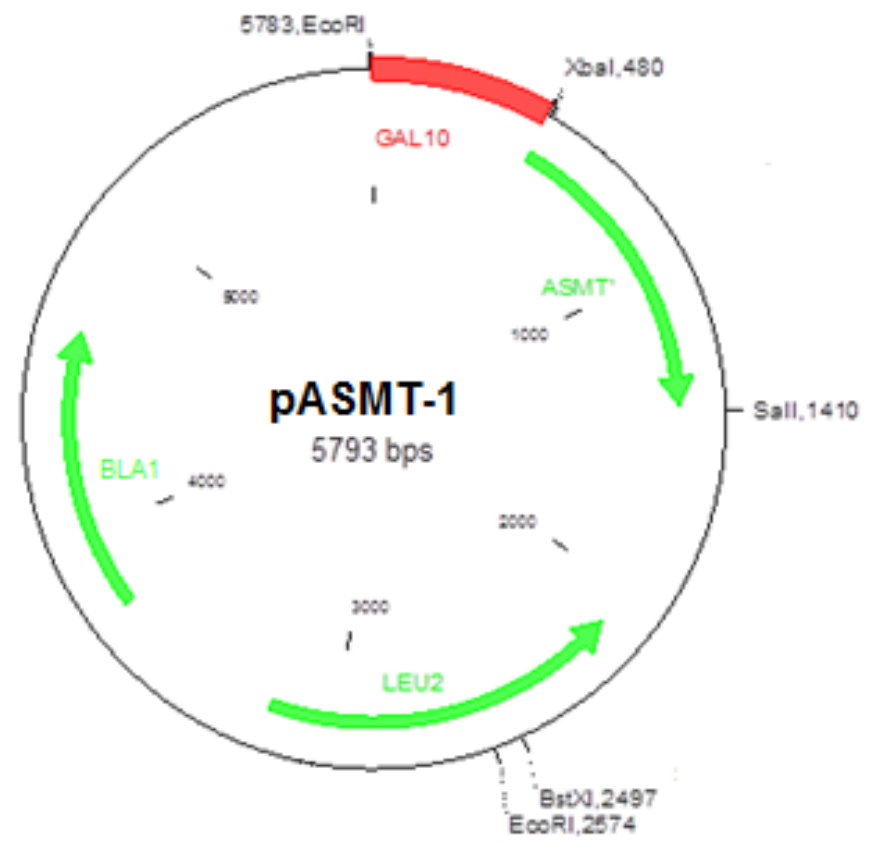

Em destaque, estão os sítios de restrição relevantes para clonagens e os genes de seleção de leveduras em meio mínimo sem leucina (LEU2). Blal codifica a proteína $\beta$-lactamase, que torna as bactérias transformadas resistentes à ampicilina.

Confirmada a clonagem do gene ASMT por sequenciamento e alinhamento com o banco de dados de nucleotídeos, o cassete de expressão GAL10-ASMT foi amplificado por PCR utilizando como molde o plasmídio esquematizado na figura acima e os oligonucleotídeos da tabela 3.5. A cauda 6 xHis foi substituída pela HA.

Tabela 3.5 - Sequência dos oligonucleotídeos utilizados para clonagem do cassete de expressão GAL10-ASMT no vetor recombinante pMLT6.

\begin{tabular}{ccc}
\hline Oligonucleotídeo & Sequência & Posição \\
\hline GAL-ASMT (Forward primer) & 5'GGGGAATTCGAGCTCCTTCGCTGATTA3' & $+2793 \mathrm{C}$ \\
\hline ASMT-HA (Reverse primer) & $\begin{array}{c}\text { 5'GGCGAATTCTCAAGCGTAGTCTGGGACGTC } \\
\text { GTATGGGTATATTTCCTGGCTAAAATGGC3' }\end{array}$ & +1425 \\
\hline
\end{tabular}

As sequências sublinhadas equivalem, nos dois oligonucleotídeos, ao sítio de clonagem EcoRI. A sequência em negrito corresponde à cauda HA. 
O fragmento amplificado, de $1440 \mathrm{pb}$, correspondente ao cassete GAL10-ASMT, foi recuperado e digerido com EcoRI. Ele foi, então, clonado no plasmídio YIplac204 já contendo o cassete GAL10-PAA1, previamente digerido com a mesma enzima de restrição, resultando na construção pMLT10, esquematizada na figura 3.7. A clonagem foi confirmada por sequenciamento e alinhamento do vetor recombinante.

Figura 3.7 - Representação esquemática do vetor integrativo pMLT10, contendo os genes $A S M T$ e PAAl com a expressão regulada pelo promotor GAL10.

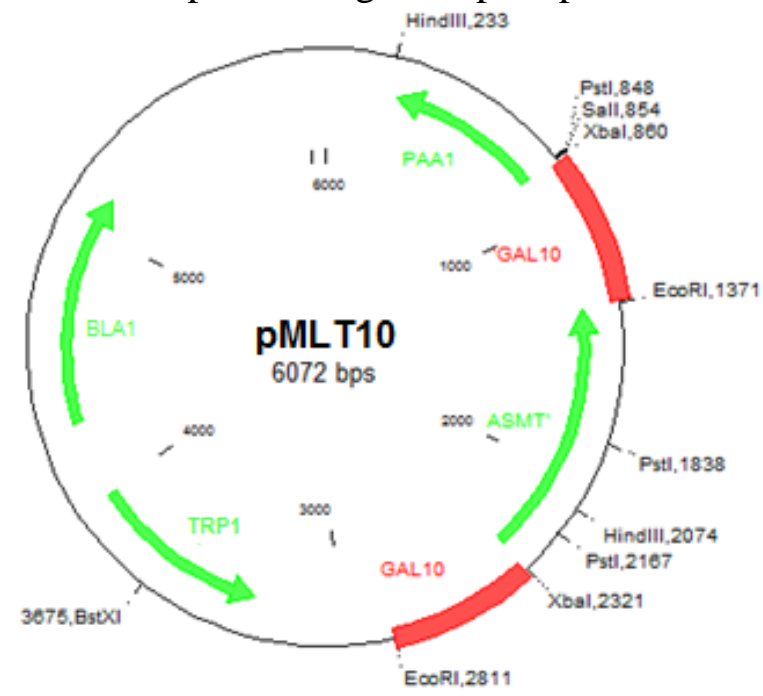

Em destaque, estão os sítios de restrição relevantes para clonagens e os genes de seleção de leveduras em meio mínimo sem triptofano $(T R P 1)$. Blal codifica a proteína $\beta$-lactamase, que torna as bactérias transformadas resistentes à ampicilina.

\subsection{Testes de Crescimento}

As linhagens recombinantes purificadas são, primeiramente, transferidas para placas de meio seletivo auxotrófico (meio mínimo suplementado com aminoácidos), visando selecionar células com pDNA estável.

Os transformantes contendo plasmídios integrativos (expressando os genes da via biossintética da melatonina) são então transferidos para placa de meio rico não seletivo com glicose e, depois, para placas de meio rico com galactose (indutor de GAL10), a fim de ativar o promotor e a expressão do gene enxertado no vetor recombinante.

Já os transformantes expressando apenas o gene $S N C A$, produtor de $\alpha$-sinucleína em plasmídio epissomal, (figura 3.1), ou expressando $\alpha$-sin e as enzimas da via da melatonina são mantidos em placas de meio mínimo suplementado com aminoácidos específicos, a fim de manter a seleção dos plasmídios epissomais. 
Alíquotas das linhagens são crescidas a $30{ }^{\circ} \mathrm{C}$ por uma noite em $10 \mathrm{ml}$ de meio rico não seletivo ou por duas noites em meio mínimo, e inoculadas em $10 \mathrm{ml}$ meio seletivo respiratório (etanol/glicerol ou meio mínimo contendo etanol/glicerol) para uma absorbância inicial de 0,1OD a $600 \mathrm{~nm}$. As medidas de absorbância são tomadas em intervalos regulares de tempo, e o tempo de geração, de cada amostra, calculado e analisado estatisticamente. $\mathrm{O}$ ensaio tem duração de até seis dias. Ao final do experimento, quantidades iguais de células de todas as linhagens são espalhadas em meio rico a fim de verificar possíveis contaminações.

\subsection{Testes de Viabilidade Celular: Desafios com Oxidantes}

Para os desafios com oxidantes, células foram crescidas por uma noite (meio rico, glicose ou galactose) ou por duas a quatro noites (meio mínimo) para um aumento significativo da massa celular. Para avaliar o efeito protetor de melatonina, o pré-crescimento é feito na presença de $10 \mu \mathrm{M}$ ou de $100 \mu \mathrm{M}$ da substância.

As células são centrifugadas e, então, inoculadas, a uma OD600=1,0, em $2 \mathrm{~mL}$ de água contendo oxidantes (menadiona e peróxido de hidrogênio) em diferentes concentrações, onde serão incubadas, com agitação, por sessenta minutos a $30{ }^{\circ} \mathrm{C}$. A centrifugação é necessária para lavar o meio de cultura, evitando sua interferência no desafio com os oxidantes.

Após esse período, as células são diluídas serialmente dez vezes e $3 \mu \mathrm{L}$ de cada diluição é plaqueada em meio rico com glicose e em meio seletivo respiratório. Plaqueiam-se, também, cerca de 150 células em meio rico com glicose para contagem de unidades formadoras de colônias (UFC) viáveis, que são incubadas a $30^{\circ} \mathrm{C}$ por três dias. O número de UFC viáveis que passaram pelo desafio com o oxidante é plotado em um gráfico em relação ao controle da mesma linhagem, ou seja, células que passaram pelo desafio com apenas água. Essa razão desafio/controle é analisada e comparada entre as linhagens estatisticamente. 


\section{RESULTADOS E DISCUSSÃO}

\subsection{Ensaios de crescimento e desafios com oxidantes}

4.1.1 Leveduras, expressando múltiplas cópias do gene SNCA, apresentam crescimento reduzido em meio seletivo para a atividade respiratória.

Como mostrado por Junn e Mouradian (2002), neuroblastos expressando $\alpha$-sin selvagem e mutante possuem altos níveis intracelulares de ROS, além de terem uma diminuição na viabilidade celular quando expostos à dopamina, consistente com a hipótese de que níveis maiores de $\alpha$-sin promovem apoptose em neurônios dopaminérgicos.

Visando testar o modelo parkinsoniano de S. cerevisiae, células transformadas foram submetidas a ensaios de crescimento em meio seletivo para atividade respiratória (contendo etanol e glicerol como fontes de carbono não fermentável), considerando que os níveis de ROS aumentados resultem de disfunção mitocondrial causada pela presença de $\alpha$-sinucleína nessas células e que isso reduziria o crescimento nessas fontes de carbon.

As linhagens W303-1A, PD2 (GAL10-SNCA-6xHis), PD3 (GPD1-SNCA-6xHis) e PD4 (TEF2-SNCA-6xHis) tiveram a transcrição do gene SNCA ativada no pré-inóculo (meio rico com galactose) e foram, então, transferidas para meio para seleção da atividade respiratória.

Figura 4.1 - Teste de crescimento em meio rico respiratório envolvendo as linhagens W3031A, PD2 (GAL10-SNCA-6xHis), PD3 (GPD1-SNCA-6xHis) e PD4 (TEF2SNCA-6xHis). $\mathrm{N}=3$.

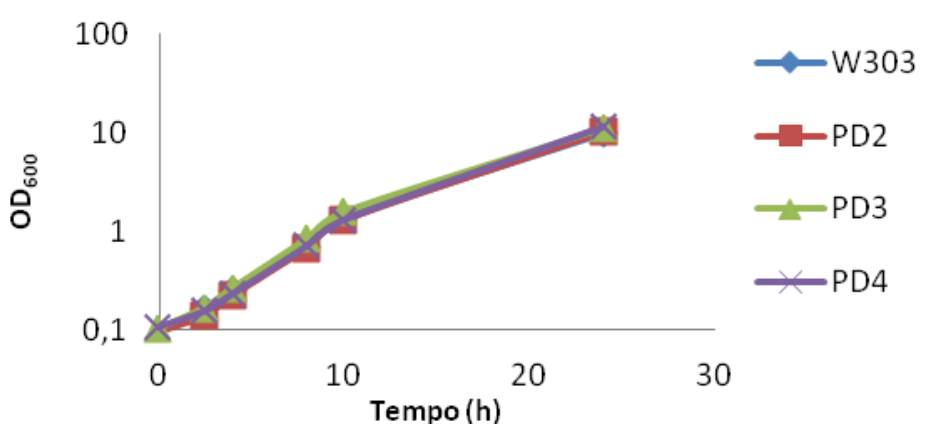

Como visto na figura 4.1, células contendo vetores integrativos não apresentaram diferença significativa em seu padrão de crescimento quando comparadas às células W3031A, mesmo se os níveis de expressão forem altos, controlados pelo promotor GAL10. Na 
tabela abaixo, estão relacionados os tempos de geração dessas linhagens, ou seja, o intervalo de tempo necessário para uma população dobrar seu número de indivíduos. Considerando o gráfico e a tabela, observa-se que não há diferença significativa do crescimento dessas linhagens em meio seletivo para atividade respiratória.

Tabela 4.1 - Tempos de geração em meio rico respiratório das linhagens W303, PD2, PD3 e PD4.

\begin{tabular}{ccc}
\hline Linhagem & $\begin{array}{c}\text { Média dos tempos de geração } \\
(\mathbf{h})\end{array}$ & Desvio Padrão \\
\hline W303 & 3,14 & 0,27 \\
PD2 & 2,9 & 0,24 \\
PD3 & 2,74 & 0,19 \\
PD4 & 2,6 & 0,18 \\
\hline
\end{tabular}

Não há diferenças significativas de crescimento $(\mathrm{n}=3$; Teste $T$ de Student em relação a W303: PD2 p=0,53; PD3 p=0,17; PD4 p=0,064).

O resultado com os vetores integrativos sugeriu que o efeito tóxico não observado pode ser devido ao número de cópias de SNCA no genoma. Assim, células com o vetor epissomal pEG(KG)-SNCA foram testadas em meio mínimo respiratório, suplementado com os aminoácidos necessários, e comparadas à linhagem parental (figura 4.2). Observa-se que, nesse caso, há deficiência no crescimento das linhagens expressando o gene SNCA, evidenciada pelo aumento significativo de seus tempos de geração $(p<0,0001)$, como mostrado na tabela 4.2 .

Figura 4.2 - Teste de crescimento em meio mínimo seletivo para atividade respiratória envolvendo as linhagens W303-1A e W303-1A PD1 (pEG(KG)-SNCA).

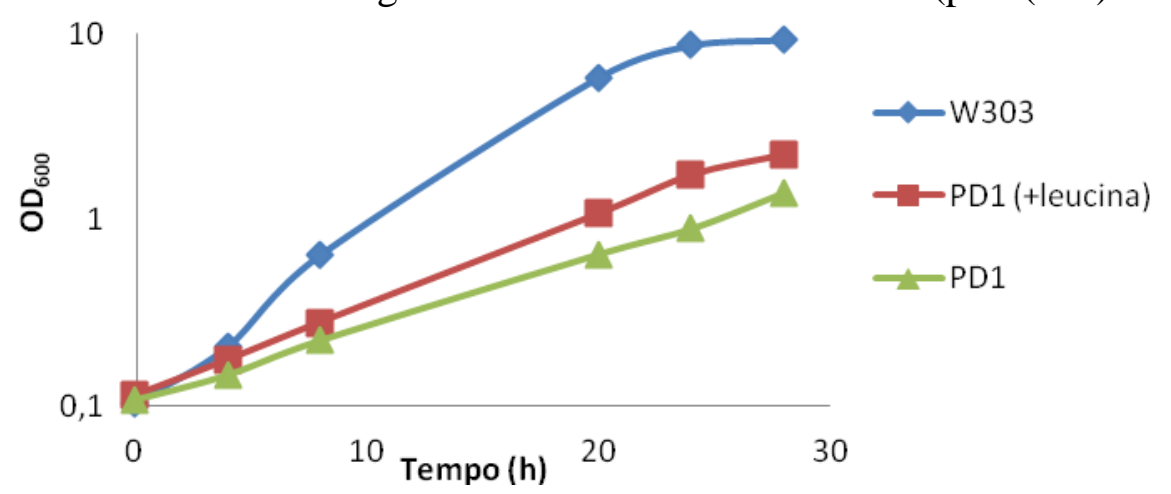

As leveduras foram suplementadas com os aminoácidos necessários. PD1 teve o número de cópias do plasmídio pEG(KG)-SNCA modulada com a suplementação com leucina: na ausência desse aminoácido, o número de cópias é maior, agravando o fenótipo de PD. N=3. 
Tabela 4.2 - Tempos de geração em meio mínimo com seleção para atividade respiratória das linhagens W303 e PD1.

\begin{tabular}{ccc}
\hline Linhagem & $\begin{array}{c}\text { Média dos tempos de geração } \\
(\mathbf{h})\end{array}$ & Desvio Padrão \\
\hline W303 & 2,64 & 0,28 \\
PD1 + leucina & 6,24 & 0,25 \\
PD1 & 8,28 & 0,35 \\
\hline
\end{tabular}

As leveduras tiveram pré-crescimento em meio mínimo com galactose e o número de cópias do gene $S N C A$, na linhagem PD1, é maior na ausência de leucina. $\mathrm{N}=3$.

4.1.2 Leveduras parkinsonianas exibem maior sensibilidade ao estresse oxidativo causado por menadiona

Diversas evidências apontam para o estresse oxidativo como componente central da doença de Parkinson. Como visto por Junn e Mouradian (2002), o aumento dos níveis de $\alpha$ sin está relacionado à disfunção mitocondrial, causando estresse oxidativo. Já que os neurônios dopaminérgicos são intrinsecamente suscetíveis a ROS, o aumento do estresse oxidativo a partir de disfunção mitocondrial é muito danoso, agravando a doença de Parkinson (HWANG, 2013).

Para melhor entendermos como o estresse oxidativo afetaria as células de $S$. cervisiae produtoras de $\alpha$-sinucleína, desafios com $500 \mu \mathrm{M}$ peróxido de hidrogênio $\left(\mathrm{H}_{2} \mathrm{O}_{2}\right)$ e com 750 $\mu \mathrm{M}$ menadiona foram realizados, conforme descrito anteriormente.

$\mathrm{O}$ peróxido de hidrogênio $\left(\mathrm{H}_{2} \mathrm{O}_{2}\right)$ é uma espécie reativa de oxigênio (ROS) não radicalar, resultado da dismutação do ânion radical superóxido (BOVERIS; CHANCE, 1973). A produção de $\mathrm{H}_{2} \mathrm{O}_{2}$ pode levar a danos através da geração de radical hidroxila $\left(\mathrm{OH}^{*}\right)$, altamente reativo, produzido por reações de Fenton.

A menadiona (2-metil-1,4-naftoquinona) é uma cetona policíclica aromática, precursora da vitamina K, sendo um composto capaz de gerar ROS no ciclo redox, ao sofrer a ação de enzimas redutoras, como a NADH ubiquinona oxidorredutase mitocondrial. Essa redução de um elétron gera radicais semiquinona, os quais, em condições aeróbicas, participam do ciclo redox e geram ROS, como o ânion superóxido e o peróxido de hidrogênio (CRIDDLE et al., 2006). Castro e colaboradores (2008) mostraram que, em S. cerevisiae, a administração de menadiona gera um aumento dos níveis de ROS em decorrência da diminuição de glutationa reduzida em relação à sua forma oxidada.

Após crescimento nas condições do desafio, as linhagens foram plaqueadas em glicose e incubadas a $30^{\circ} \mathrm{C}$ por três dias. $\mathrm{O}$ número de sobreviventes foi plotado em relação à linhagem 
parental (W303 em glicose ou em galactose). Como não observamos variações significativas durante os desafios com $\mathrm{H}_{2} \mathrm{O}_{2}$, apenas os desafios com menadiona foram analisados estatisticamente (teste $T$ de Student).

Figura 4.3 - Desafio com menadiona $(750 \mu \mathrm{M})$ das linhagens W303 e PD1 (pEG(KG)$S N C A$ ) com pré-crescimento em meio mínimo com glicose (apenas W303, esquerda) ou com galactose.

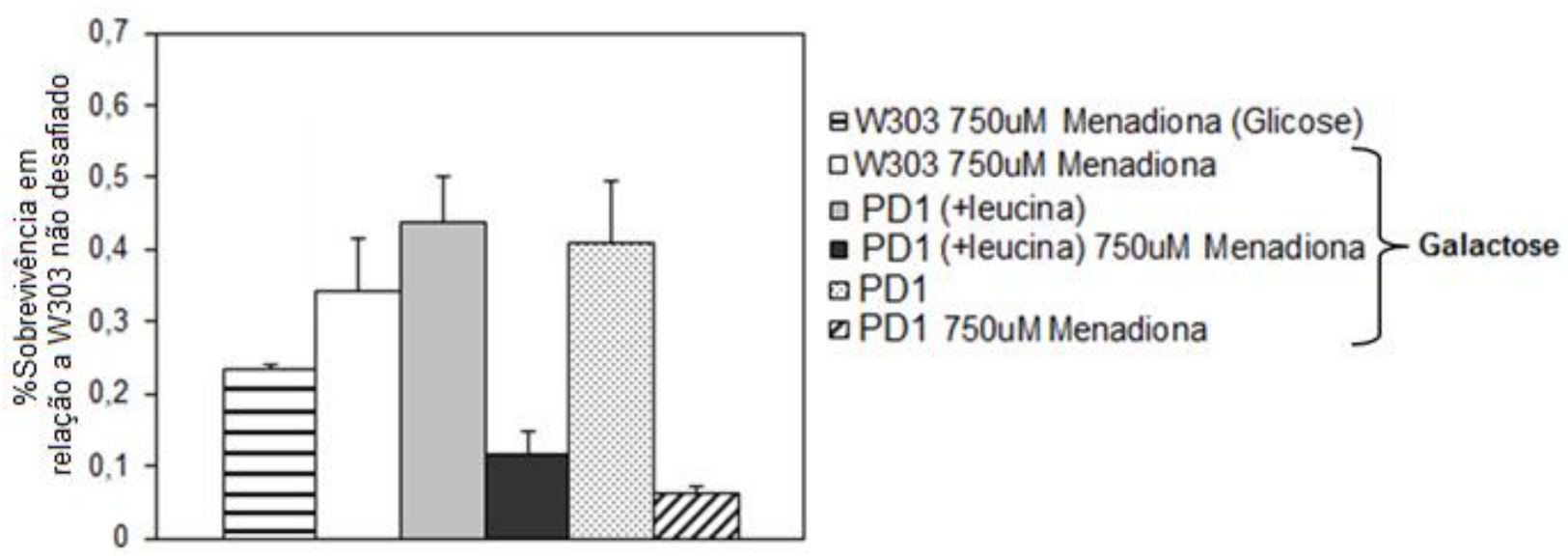

O crescimento celular, plotado em relação a W303 sem menadiona (sobrevivência=1,0), é na prejudicado presença do oxidante $(\mathrm{n}=3$; Teste $T$ de Student $\mathrm{p}<0,0001$; desvio padrão: $\mathrm{W} 303$ (+menadiona) $=0,007 ; \quad S N C A \quad$ (leucina) $=0,062 ; \quad S N C A \quad$ (leucina+menadiona) $=0,032$; $S N C A=0,088 ; S N C A$ (+menadiona) $=0,009)$.

Na figura acima, considerando a linhagem W303, crescida tanto em meio mínimo com glicose quanto com galactose, o decréscimo da viabilidade após o desafio com menadiona é similar ( $p=0,0941)$, sendo este significativo quando comparado à condição controle, sem o agente oxidante $(p<0,0001)$. Como o decréscimo é similar para células crescidas em glicose e em galactose, as análises serão feitas somente para as células crescidas em galactose, situação em que a expressão do gene $S N C A$ está ativada.

Interessantemente, a diminuição do número de células W303 sobreviventes ao desafio com menadiona não é significativamente diferente do número de células sobreviventes produtoras de $\alpha$-sin (W303 em relação a PD1: $p=0,1963$; com leucina: $p=0,1283$ ), sendo que não houve diferença significativa em relação ao número de cópias da construção $\mathrm{pEG}(\mathrm{KG})$ SNCA $(p=0,0691)$. Dessa forma, podemos dizer que a simples expressão do gene SNCA em S.cerevisiae é tão prejudicial quanto o desafio com oxidantes, como a menadiona, sugerindo que $\alpha$-sin tem um papel importante para a toxicidade do estresse oxidativo em leveduras, assim como visto em outros organismos modelos.

Assim como a linhagem parental, a linhagem parkinsoniana teve redução significativa de sua viabilidade frente ao desafio com menadiona ( $p<0,0001)$, mas, considerando o número 
de cópias, não houve diferença significativa entre os desempenhos ( $\mathrm{p}=0,0185)$. Adicionalmente, os ensaios de crescimento por diluições seriadas (figura 4.4) mostram, qualitativamente, o prejuízo da ativação desse gene nas linhagens parkinsonianas, que são mais sensíveis ao crescimento em etanol-glicerol, indicando uma provável deficiência respiratória, apesar de não terem sido observadas diferenças significativas na frequência de formação de petites após os desafios.

Figura 4.4 - Ensaio de crescimento por diluições seriadas, em glicose (meio fermentável) e em etanol glicerol (meio seletivo para atividade respiratória), das linhagens W303 e PD1, desafiadas com $750 \mu \mathrm{M}$ de menadiona.

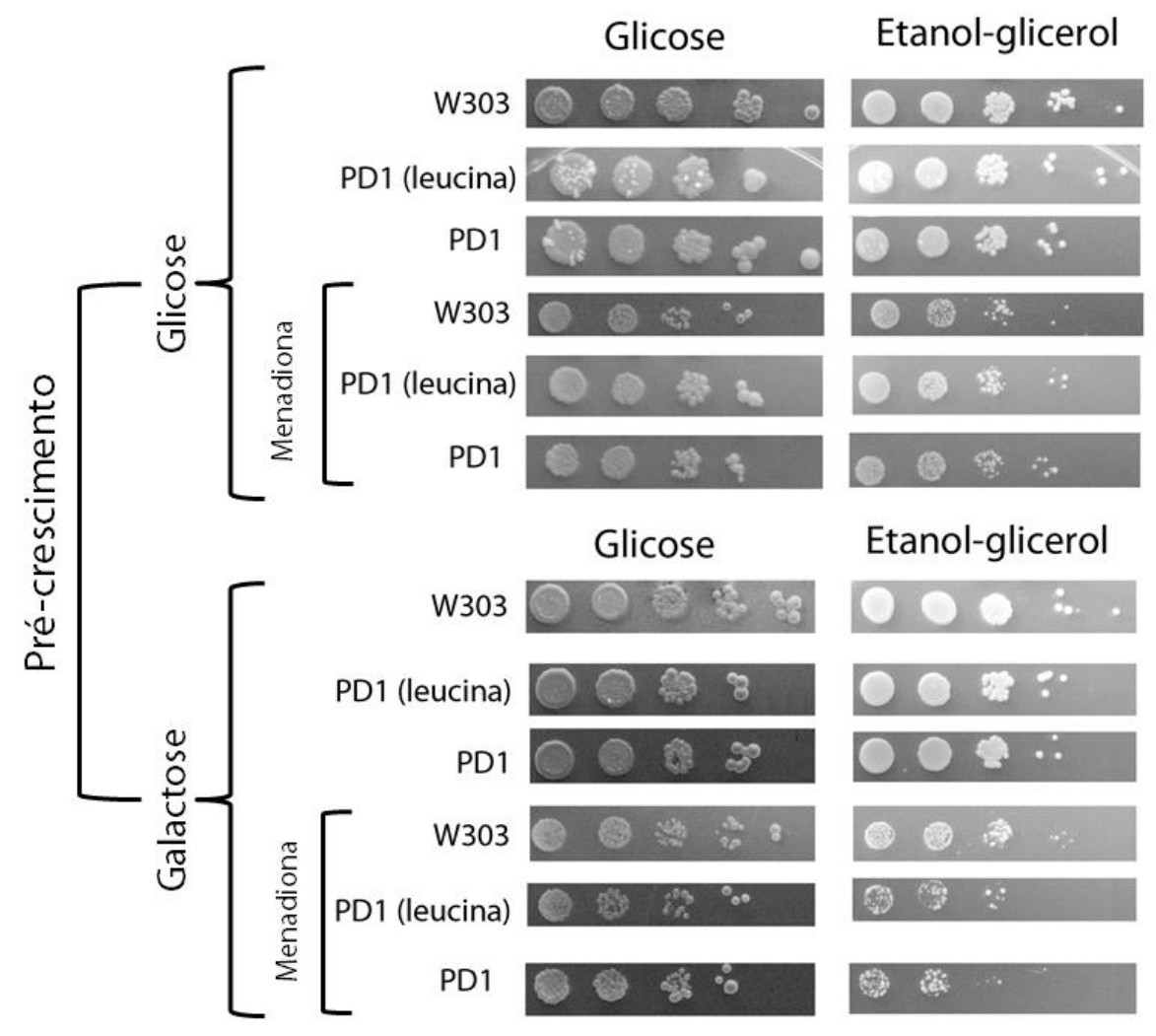

Após três dias de incubação a $30{ }^{\circ} \mathrm{C}$, as linhagens apresentam viabilidade semelhante, inclusive após o desafio. No entanto, a ativação da transcrição do gene $S N C A$ (galactose) diminui a sobrevivência após o desafio, principalmente em meio respiratório.

4.1.3 A produção de melatonina não interfere no crescimento de leveduras parentais

Como propusemos realizar a expressão de genes da via de biossíntese de melatonina como terapia contra a toxicidade de $\alpha$-sin, avaliamos o crescimento em meio mínimo, com seleção para atividade respiratória, de leveduras contendo a construção pMLT10 (Yiplac204+GAL-AANAT+GAL-ASMT). Observa-se, na figura 4.5 e na tabela 4.3, que não há 
diferença significativa no desempenho de células contendo pMLT10 em relação à linhagem parental W303-1A quando crescidas em meio mínimo seletivo para atividade respiratória, mesmo quando a expressão dos genes da via da melatonina está induzida (meio mínimo respiratório contendo galactose).

Figura 4.5 - Teste de crescimento em meio mínimo, seletivo para atividade respiratória, envolvendo as linhagens W303-1A e MLT10.

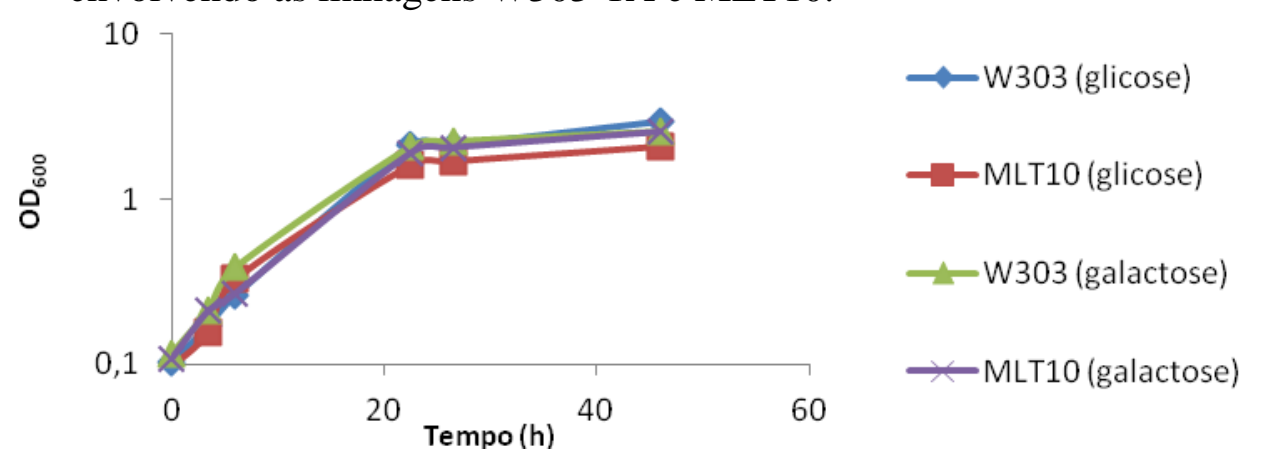

A linhagem parental foi suplementada com os aminoácidos necessários (adenina, triptofano, leucina, uracila e histidina), assim como MLT10 (adenina, leucina, uracila, histidina). A expressão dos genes da via biossintética da melatonina está desativada quando o précrescimento é feito em meio mínimo contendo glicose ou ativada em galactose. $\mathrm{N}=3$.

Tabela 4.3 - Tempos de geração em meio rico respiratório das linhagens W303 e MLT10.

\begin{tabular}{ccc} 
Linhagem & $\begin{array}{c}\text { Média dos tempos de geração } \\
(\mathbf{h})\end{array}$ & Desvio Padrão \\
\hline W303 (glicose) & 2,96 & 0,22 \\
W303 (galactose) & 3,75 & 0,13 \\
MLT10 (glicose) & 3,61 & 0,14 \\
MLT10 (galactose) & 4,56 & 0,76 \\
\hline
\end{tabular}

As linhagens W303 e MLT10, com pré-crescimento em glicose, e W303 e MLT10, com précrescimento em galactose, não possuem diferenças significativas em seu crescimento $(n=3$; Teste $T$ de Student: em glicose, $\mathrm{p}=0,038$; em galactose, $\mathrm{p}=0,142$ ).

4.1.4 A produção de melatonina confere menor sensibilidade ao estresse oxidativo causado por peróxido de hidrogênio e por menadiona

A fim de testar se a produção de melatonina confere proteção antioxidante a células de S. cerevisiae, a linhagem contendo o vetor pMLT10 foi desafiada com o peróxido de hidrogênio $(0,5 \mathrm{mM})$. Como o plasmídio é integrativo, o pré-crescimento foi feito em meio rico, contendo glicose ou galactose para induzir a expressão da via biossintética. Após uma hora em contato com o oxidante, as mesmas quantidades de células foram plaqueadas em 
glicose e, após três dias, as colônias viáveis foram contadas em relação às linhagens controle correspondentes.

Figura 4.6 - Desafio das linhagens W303 e MLT10 com $\mathrm{H}_{2} \mathrm{O}_{2}(0,5 \mathrm{mM})$.

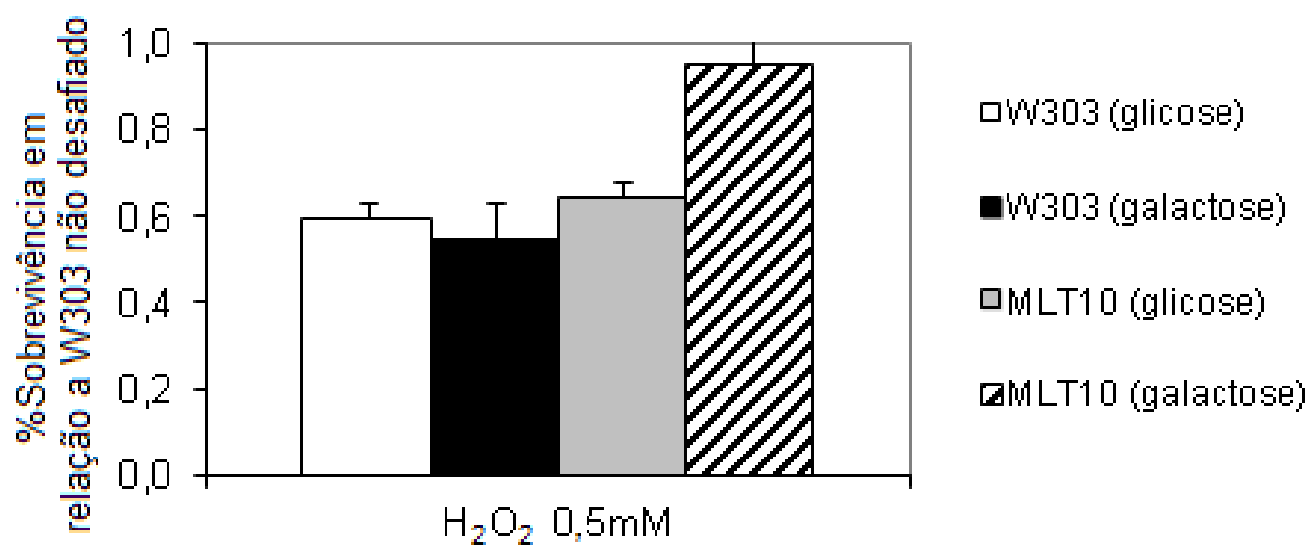

Ao enfrentar um desafio, o crescimento celular é somente recuperado na linhagem expressando as enzimas AANAT e HIOMT, em relação ao controle W303 sem menadiona (sobrevivência=1,0). $(\mathrm{N}=4$; Teste $T$ Student $p<0,0001$; desvio padrão: W303(glicose) $=0,033$; W303 $($ galactose $)=0,086 ; \operatorname{MLT10}($ glicose $)=0,038 ; \operatorname{MLT10}($ galactose $)=0,091)$.

Como observado na figura acima, as linhagens W303, crescidas em meio rico com glicose ou galactose, apresentaram uma viabilidade em torno de $60 \%$ quando desafiadas com o oxidante, o que é condizente com os resultados obtidos em meio mínimo, descritos anteriormente (figura 4.3). Pode-se considerar que não há interferência significativa das condições de pré-crescimento nesses desafios. Quando desafiada, a linhagem MLT10 crescida em glicose, sem a ativação da transcrição dos genes da via de biossíntese da melatonina, apresentou uma queda na viabilidade similar à parental. Ao induzir a transcrição gênica, isto é crescendo MLT0 em galactose, a linhagem apresenta uma viabilidade celular significativamente maior, atingindo níveis similares aos das linhagens na situação controle, ou seja, não desafiada. Esses resultados apontam para um efeito protetor antioxidante da indução da expressão dos genes da via biossintética da melatonina.

Ainda considerando as propriedades antioxidantes da construção pMLT10, as células foram submetidas a um desafio com $750 \mu \mathrm{M}$ menadiona, após pré-crescimento em meio mínimo com glicose ou galactose. Após sessenta minutos de desafio, as células foram plaqueadas em glicose e incubadas a $30{ }^{\circ} \mathrm{C}$ por três dias. As colônias viáveis foram plotadas em relação ao controle, ou seja, W303-1A crescido em meio mínimo com glicose ou com galactose, e analisadas estatisticamente pelo teste $T$ de Student. 
Figura 4.7 - Desafio das linhagens W303 e MLT10 com menadiona (750 $\mu \mathrm{M})$.

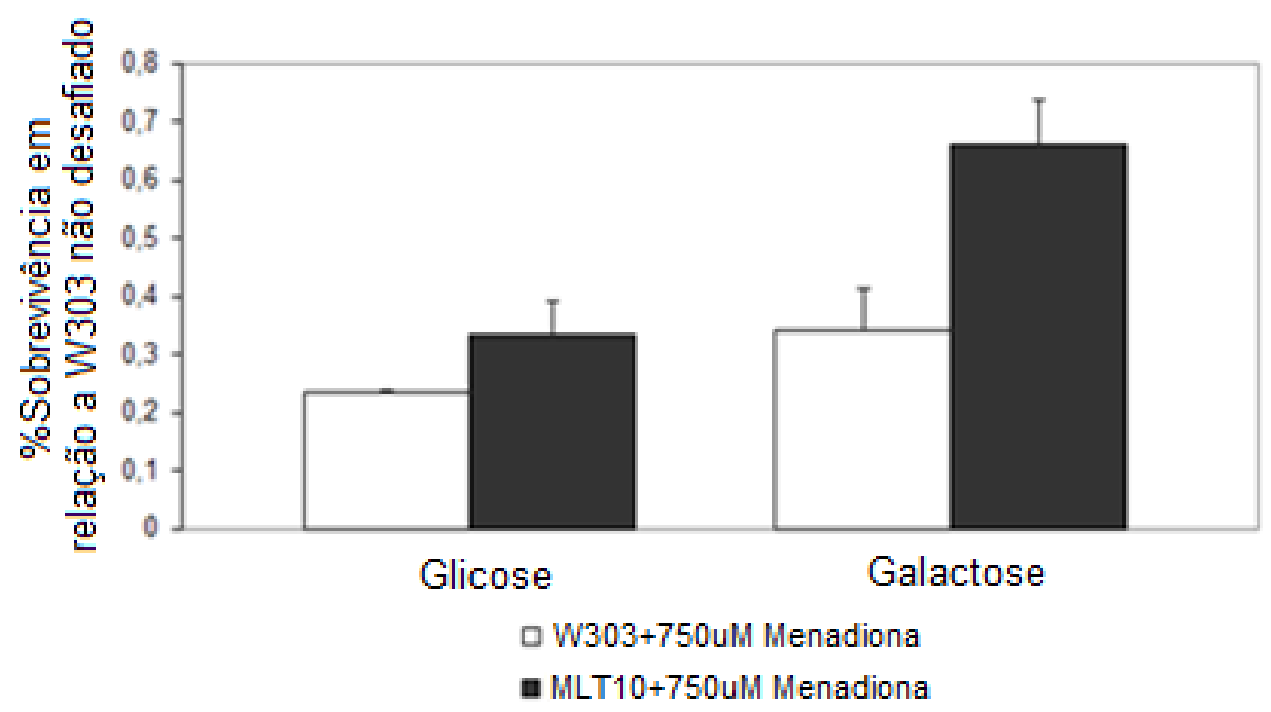

Ao enfrentar o desafio, o crescimento celular é recuperado apenas na linhagem com ativação da expressão da via biossintética da melatonina, ou seja, com pré-crescimento em meio mínimo contendo galactose, Controle: W303 sem menadiona (sobrevivência=1,0). $(\mathrm{N}=3$; Teste $T$ Student $p<0,0001$; desvio padrão: W303(glicose+menadiona) $=0,006$; W303 $($ galactose + menadiona $)=0,072 ; \quad \operatorname{MLT10}($ glicose $)=0,12 ; \quad$ MLT10 $($ galactose $)=0,19 ;$ MLT10 (galactose+menadiona $)=0,076)$.

Comparando W303 e MLT10 na presença de menadiona, observa-se que a redução na viabilidade, em meio mínimo com glicose, é similar ( $p=0,086)$, mas, em galactose, as células contendo pMLT10 apresentam maior viabilidade $(p<0,0001)$, mostrando que a produção de melatonina confere proteção ao dano oxidativo causado por menadiona. Análises qualitativas de crescimento por diluições seriadas (figura 4.8) mostram que as células contendo a construção pMLT10, com sua transcrição ativada por galactose, apresentam melhora no crescimento em etanol/glicerol. Essa melhora qualitativa também é perceptível em meio respiratório. Pode-se afirmar que essa construção confere proteção antioxidante contra peróxido de hidrogênio (figura 4.6) e contra menadiona (figura 4.7), indicativo de um espectro de ação razoável da melatonina, já que os dois oxidantes usados nos experimentos possuem ações celulares distintas. 
Figura 4.8 - Ensaio de crescimento por diluições seriadas, em glicose (meio fermentável) e em etanol-glicerol (meio respiratório), das linhagens W303-1A e MLT10, após desafio com $750 \mu \mathrm{M}$ menadiona.

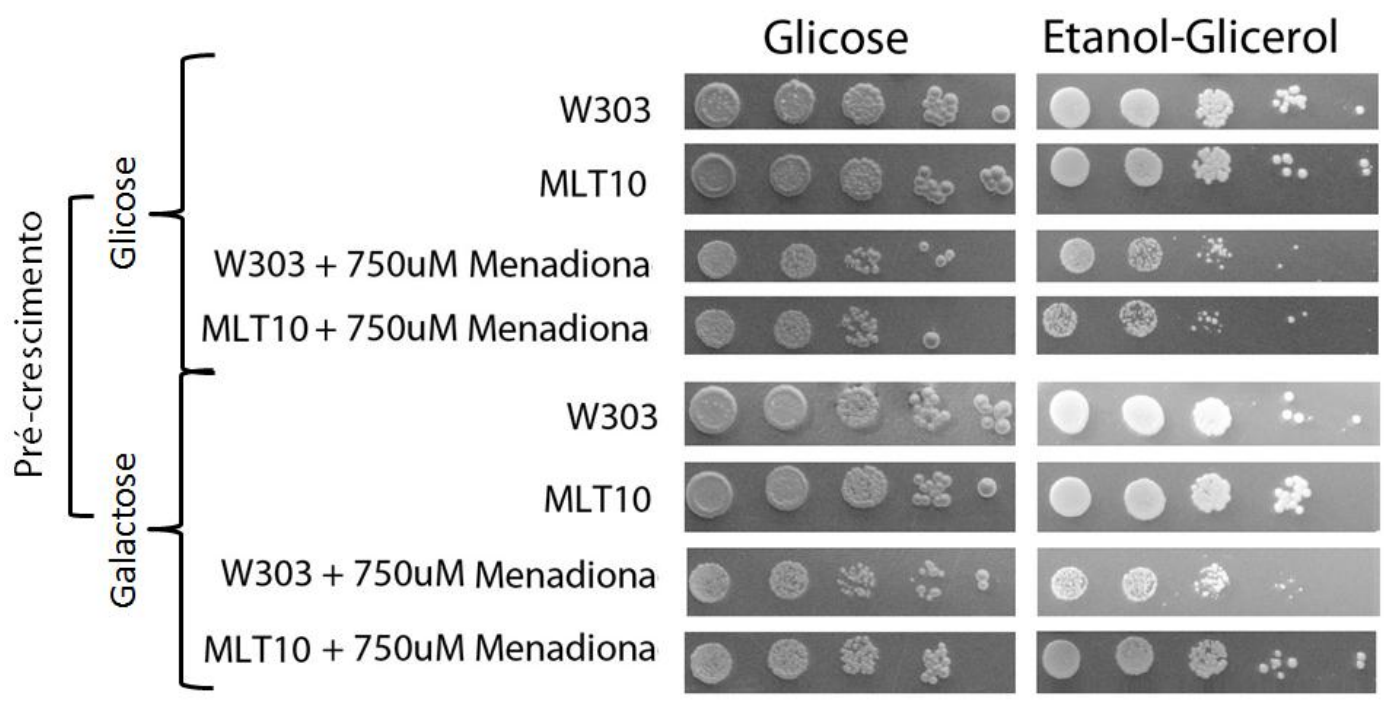

Após três dias de incubação a $30^{\circ} \mathrm{C}$, observa-se uma melhora no desempenho respiratório (etanol glicerol) de MLT10, com a transcrição gênica ativada em galactose (meio mínimo), quando desafiada com menadiona, em relação a W303 e a MLT10 (pré-crescimento em meio mínimo com glicose).

Infelizmente, não observamos variações significativas na sobrevivência da linhagem MLT10, cotransformada com pEG(KG)-SNCA, em relação à linhagem PD1. Dessa forma, optamos por realizar a suplementação farmacológica de melatonina a fim de caracterizarmos se a substância poderia conferir, também, proteção à citotoxidade observada pela produção de $\alpha$-sin em leveduras.

4.1.5 A suplementação com dose farmacológica de melatonina confere proteção aos efeitos citotóxicos de $\alpha$-sinucleína

Como visto nos experimentos anteriores, a melatonina confere proteção ao dano oxidativo por peróxido de hidrogênio e por menadiona. Sabendo que o estresse oxidativo está muito associado à progressão da doença de Parkinson, foi realizada a suplementação de melatonina em leveduras produtoras de $\alpha$-sin, a fim de melhor caracterizar seu efeito no crescimento em meio mínimo respiratório e na sobrevivência das linhagens desafiadas com menadiona $(750 \mu \mathrm{M})$.

Estudos apontam que os níveis fisiológicos de melatonina no plasma humano são de 10 nM (CHAKRAVARTY; RIZVI, 2011) e que alguns dos efeitos terapêuticos só são 
alcançados apenas com doses farmacológicas: por exemplo, estudos realizados em cérebros de ratos revelaram que a melatonina a $100 \mu \mathrm{M}$ é capaz de diminuir o dano oxidativo causado por agregados de peptídeo $\beta$-amilóide na doença de Alzheimer, enquanto um aumento de dez vezes em sua concentração aumenta o estresse oxidativo (CLAPP-LILLY et al., 2001), mostrando que doses farmacológicas mais próximas dos níveis fisiológicos são desejadas para o tratamento de doenças. A fim de verificar a dose de melatonina mais eficaz contra a citotoxidade de $\alpha$-sin aliada ao estresse oxidativo conferido, em um primeiro momento, avaliamos qualitativamente o desempenho de leveduras parkinsonianas frente a desafios com menadiona $(750 \mu \mathrm{M})$, utilizando duas concentrações de melatonina $(10 \mu \mathrm{M}$ e $100 \mu \mathrm{M})$ durante o pré-crescimento em meio mínimo com galactose, que simulam a situação mais agressiva da doença.

Como visto anteriormente (figuras 4.2 e 4.3), a produção de $\alpha$-sin é prejudicial à atividade respiratória de $S$. cerevisiae. No entanto, na figura abaixo, melatonina a $10 \mu \mathrm{M}$ foi mais eficaz para melhorar o desempenho respiratório da linhagem produtora de $\alpha$-sinucleína, sugerindo um efeito citoprotetor com essa dosagem mais próxima à fisiológica, a qual foi utilizada nos experimentos seguintes.

Figura 4.9 - Ensaio de crescimento por diluições seriadas mostram o efeito protetor da melatonina em células expressando $\alpha$-sinucleína.

Glicose

WT
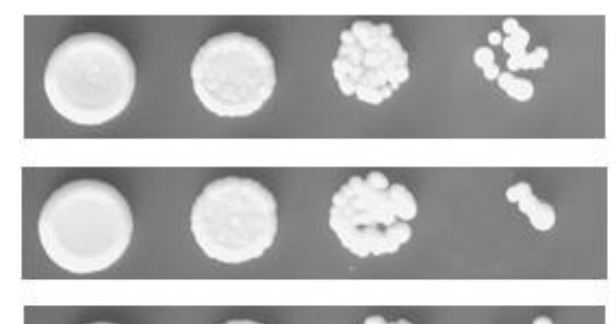

$\left[\begin{array}{r}\text { sem MLT } \\ 10 \mu \mathrm{M} \text { MLT } \\ 100 \mu \mathrm{M} \text { MLT }\end{array}\right.$

\section{Etanol-Glicerol}
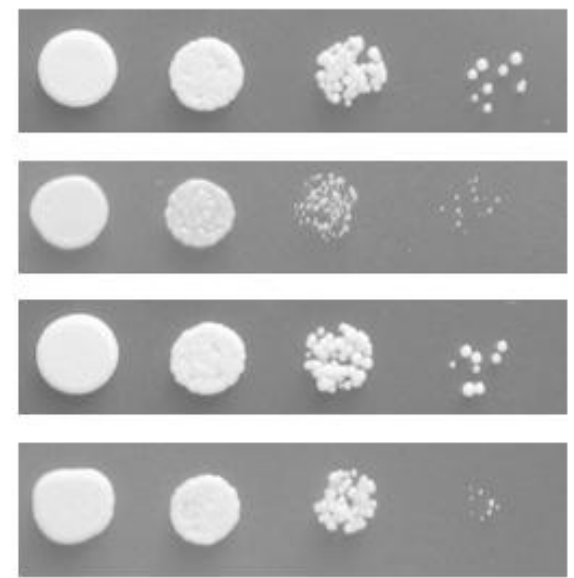

A linhagem PD1 teve pré-crescimento em meio mínimo com galactose, contendo quantidades variáveis de melatonina. W303 foi utilizada como controle. Após três dias de incubação a $30{ }^{\circ} \mathrm{C}$, há uma melhora em seu desempenho respiratório com tratamento prévio com $10 \mu \mathrm{M}$ melatonina. 
Visando avaliar quantitativamente o papel citoprotetor de melatonina $(10 \mu \mathrm{M})$ no desempenho respiratório das células parkinsonianas, o crescimento de leveduras foi monitorado por $92 \mathrm{~h}$ em meio mínimo respiratório (figura 4.10).

Figura 4.10 - Teste de crescimento em meio mínimo, seletivo para atividade respiratória, envolvendo as linhagens W303-1A, W303 contendo o vetor vazio $\mathrm{pEG(KG)}$ e PD1(pEG(KG)-SNCA), com pré-crescimento em meio mínimo com galactose, contendo, ou não, $10 \mu \mathrm{M}$ melatonina.
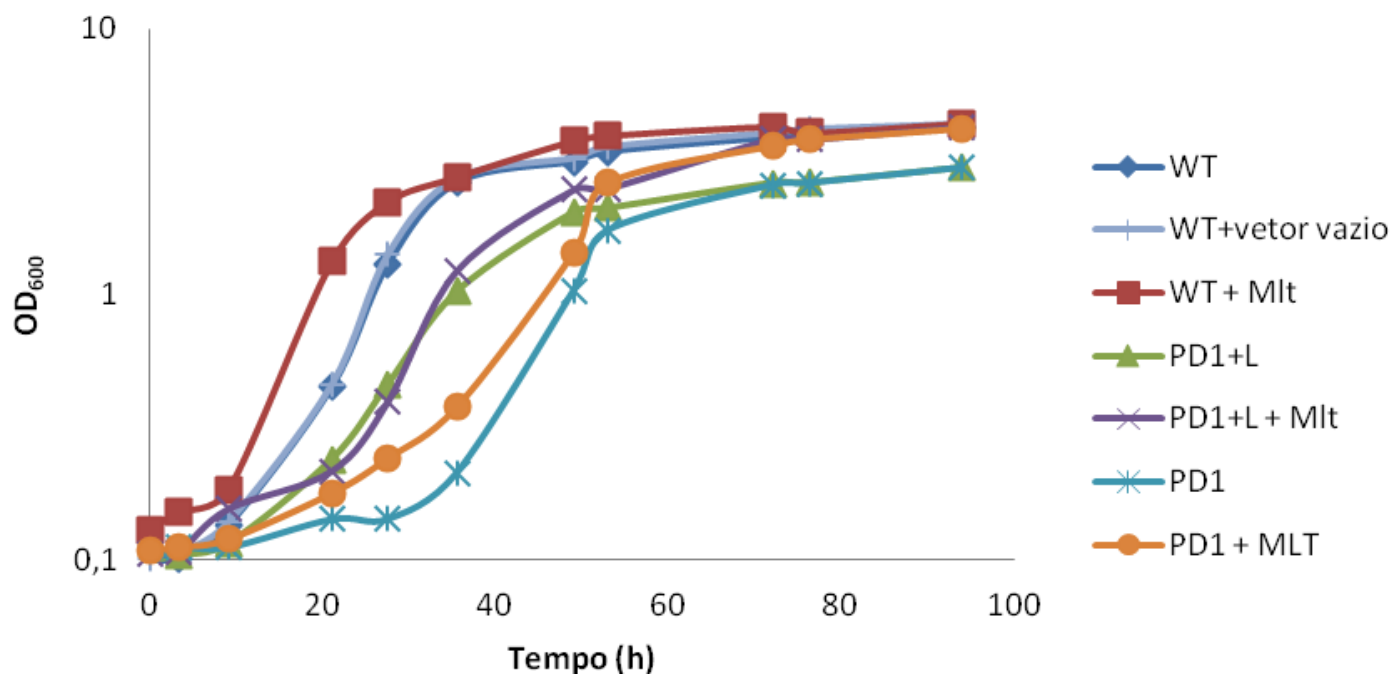

A linhagem PD1 teve o número de cópias do plasmídio $\mathrm{pEG}(\mathrm{KG})-S N C A$ modulada em meio contendo leucina (menor número de cópias) ou na ausência desse aminoácido (maior número de cópias). N=3. Mlt. Melatonina; L. leucina.

Com base nos dados acima, os tempos de geração de cada linhagem foi calculado para a fase exponencial, em que há maior crescimento populacional (tabela 4.4).

Tabela 4.4 - Tempos de geração em meio mínimo respiratório das linhagens W303 (WT) e PD1, com pré-crescimento em meio mínimo com galactose, contendo ou não $10 \mu \mathrm{M}$ melatonina $(\mathrm{n}=3)$. $\mathrm{L}=$ leucina.

\begin{tabular}{ccc}
\hline Linhagem & $\begin{array}{c}\text { Média dos tempos de geração } \\
(\mathbf{h})\end{array}$ & Desvio Padrão \\
\hline W303 & 3,63 & 0,44 \\
W303+vetor vazio & 3,49 & 0,34 \\
W303+10 $\boldsymbol{\mu M}$ melatonina & 3,63 & 0,26 \\
PD1+L & 7,25 & 0,86 \\
PD1+L+10 $\boldsymbol{\mu M}$ melatonina & 4,95 & 0,38 \\
PD1 & 19,64 & 0,59 \\
PD1+10 $\boldsymbol{\mu M}$ melatonina & 6,76 & 0,3 \\
\hline
\end{tabular}


A partir da tabela acima, observa-se que não há diferença significativa entre os tempos de geração das linhagens parentais, o que foi confirmado com o teste $T$ de Student. Para as linhagens produtoras de $\alpha$-sinucleína, observou-se um aumento significativo nos tempos de geração em relação às linhagens parentais, sendo este aumento maior com o aumento do número de cópias do gene $S N C A$. Ainda, observou-se que o pré-tratamento com melatonina $(10 \mu \mathrm{M})$ foi suficiente para diminuir significativamente o tempo de geração $(p<0,0001)$, o que significa que a população de leveduras parkinsonianas cresce efetivamente mais quando protegida pela melatonina. Esse ganho em desempenho é ainda maior a partir de $72 \mathrm{~h}$.

Com os experimentos acima, observam-se indícios muito fortes de proteção de leveduras parkinsonianas a partir da suplementação farmacológica com melatonina. Para verificar se essa suplementação seria suficiente para proteger as leveduras contra o estresse oxidativo, foram feitos desafios com menadiona $(750 \mu \mathrm{M})$. As leveduras foram pré-crescidas em meio mínimo com galactose, contendo, ou não, $10 \mu \mathrm{M}$ melatonina. Devido às propriedades antioxidantes da melatonina, todas as leveduras foram inoculadas no meio do desafio após centrifugação para remoção do meio de cultura de pré-crescimento. Ainda, o número de cópias do gene $S N C A$ foi modulado na linhagem PD1 pela suplementação com leucina, cuja ausência produziu maior toxicidade de $\alpha$-sin.

Figura 4.11 - Desafio das linhagens W303 (WT) e PD1 com menadiona $(750 \mu \mathrm{M})$ após prétratamento com $10 \mu \mathrm{M}$ melatonina.

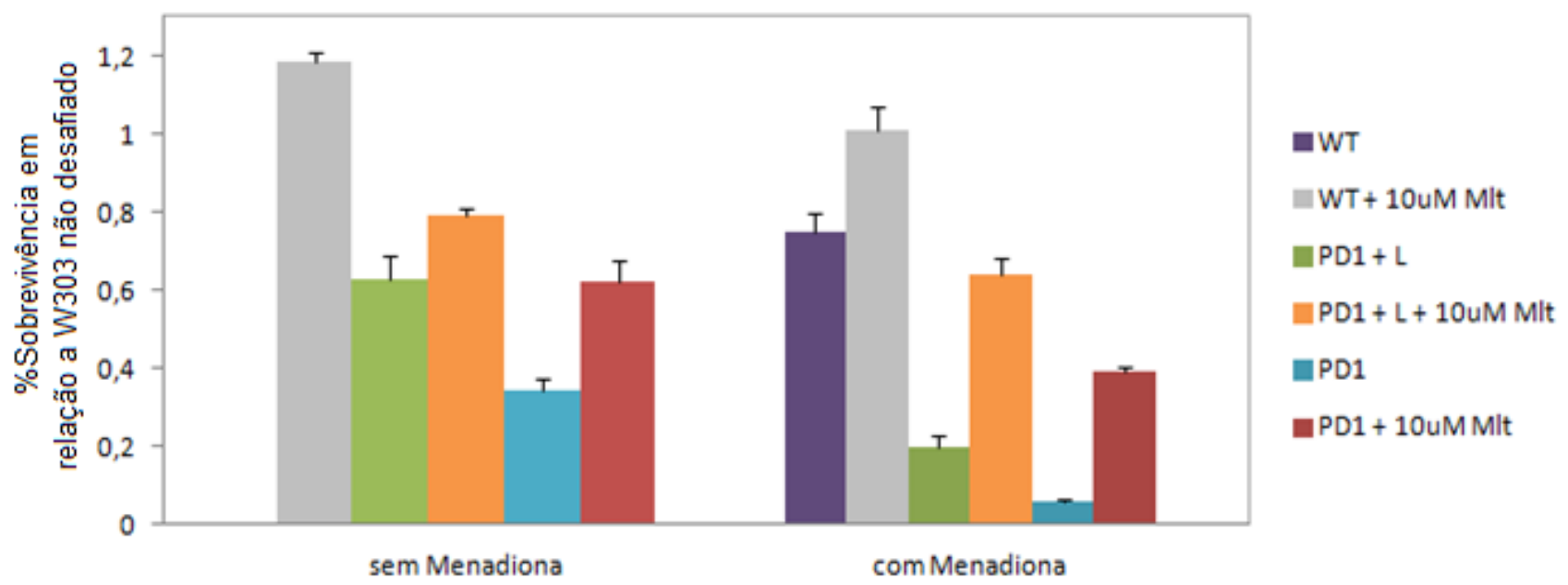

Ao enfrentar o desafio, o crescimento celular, em relação a W303 sem menadiona (sobrevivência=1,0), é recuperado em W303 e parcialmente recuperado nas leveduras parkinsonianas apenas após tratamento com melatonina (Mlt) $(\mathrm{N}=3)$.

Como visto acima, a simples produção de $\alpha$-sin por PD1 reduz significativamente sua sobrevivência em relação à linhagem parental, sendo essa redução semelhante à redução 
observada na linhagem parental quando desafiada com menadiona. Essas linhagens são parcialmente recuperadas com o pré-tratamento com melatonina.

Considerando o desafio com menadiona, observa-se que a linhagem parental apresenta redução em sua sobrevivência, que, como mencionado anteriormente, é estatisticamente semelhante à redução da sobrevivência da linhagem produtora de $\alpha$-sin. Com a suplementação com melatonina, há a recuperação dessa linhagem a níveis similares ao da situação controle. PD1 apresenta decréscimo da sobrevivência quando tratada com menadiona, que foi significativamente maior com o aumento do número de cópias do gene SNCA em PD1 sem leucina $(p<0,0001)$. Há uma significativa recuperação, ainda que parcial, dessa linhagem com o pré-tratamento com melatonina independente do número de cópias do gene $S N C A$ $(p<0,0001)$, chegando a níveis similares da linhagem parental desafiada (PD1+leucina: $p=0,0011$; PD1: $p=0,0068)$. No entanto, ao considerar a linhagem parental tratada com melatonina, a recuperação de PD1 não é tão eficiente, o que pode ser visto abaixo pelas análises qualitativas de diluições seriadas.

Figura 4.12 - Efeito protetor da melatonina em células expressando $\alpha$-sinucleína após desafio com $750 \mu \mathrm{M}$ menadiona.

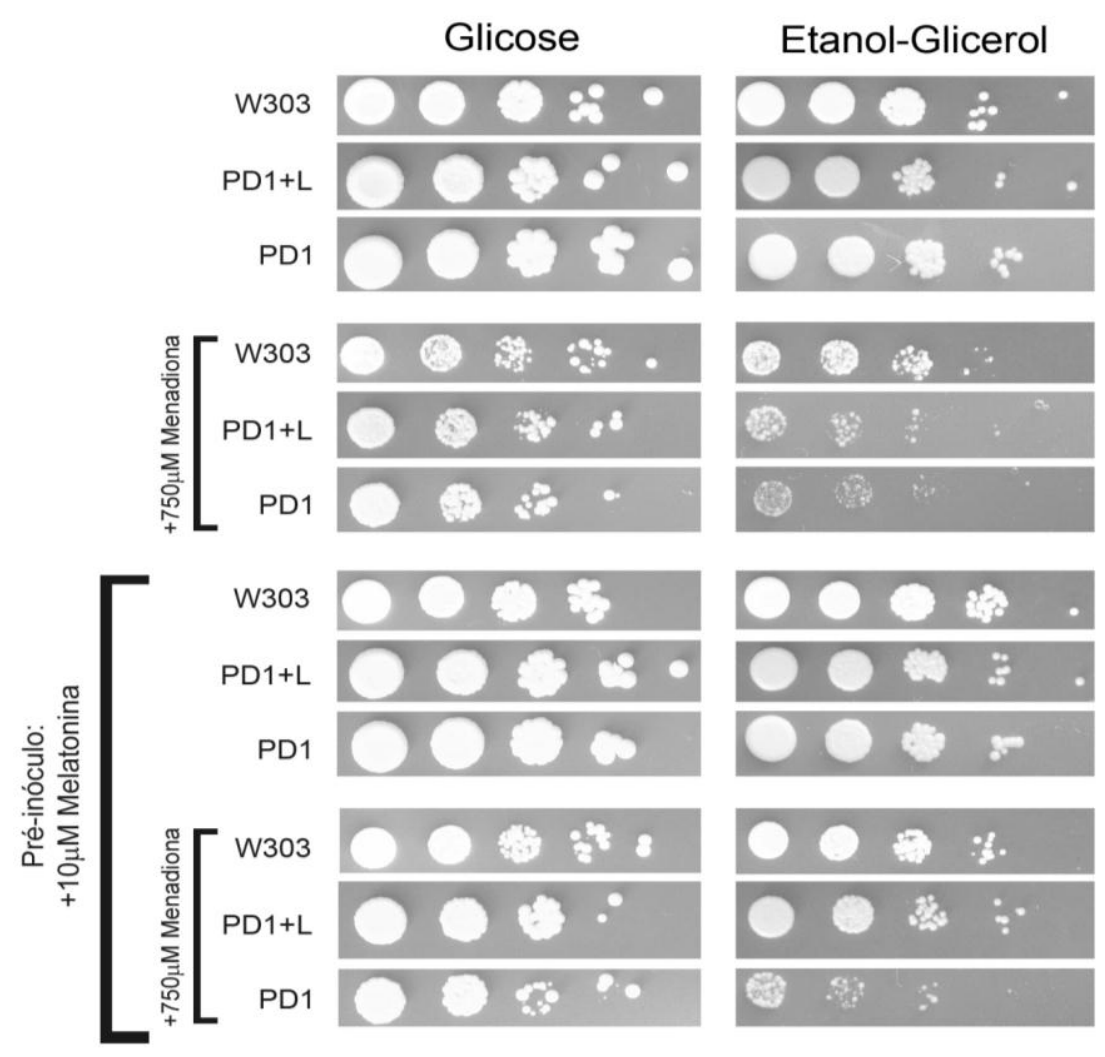

As linhagens tiveram pré-crescimento em meio mínimo com galactose, com $10 \mu \mathrm{M}$ melatonina. O número de cópias do gene $S N C A$ foi modulado pela presença (menor número) ou ausência de leucina (L) na linhagem PD1. Três dias de incubação a $30^{\circ} \mathrm{C}$. 
Adicionalmente, novos desafios com menadiona $(750 \mu \mathrm{M})$ foram realizados com a linhagem PD1, com o número de cópias do gene SNCA sendo modulado pela suplementação de leucina ou sua ausência (maior número de cópias). As células tiveram pré-crescimento em meio mínimo com galactose, suplementado ou não com duas concentrações de melatonina $(10 \mu \mathrm{M}$ e $100 \mu \mathrm{M})$ para verificar se a aparente melhora verificada no experimento anterior seria específico da dose de melatonina utilizada. Observa-se, na figura abaixo, que a dose de $10 \mu \mathrm{M}$ melatonina exerce um maior efeito protetor às células produtoras de $\alpha$-sin submetidas ao estresse com menadiona, em relação aos respectivos controles parkinsonianos, indicando que esta dose seria mais promissora para o tratamento das células.

Figura 4.13 - Desafio da linhagem PD1 com menadiona $(750 \mu \mathrm{M})$, após pré-tratamento com $10 \mu \mathrm{M}$ ou $100 \mu \mathrm{M}$ melatonina.

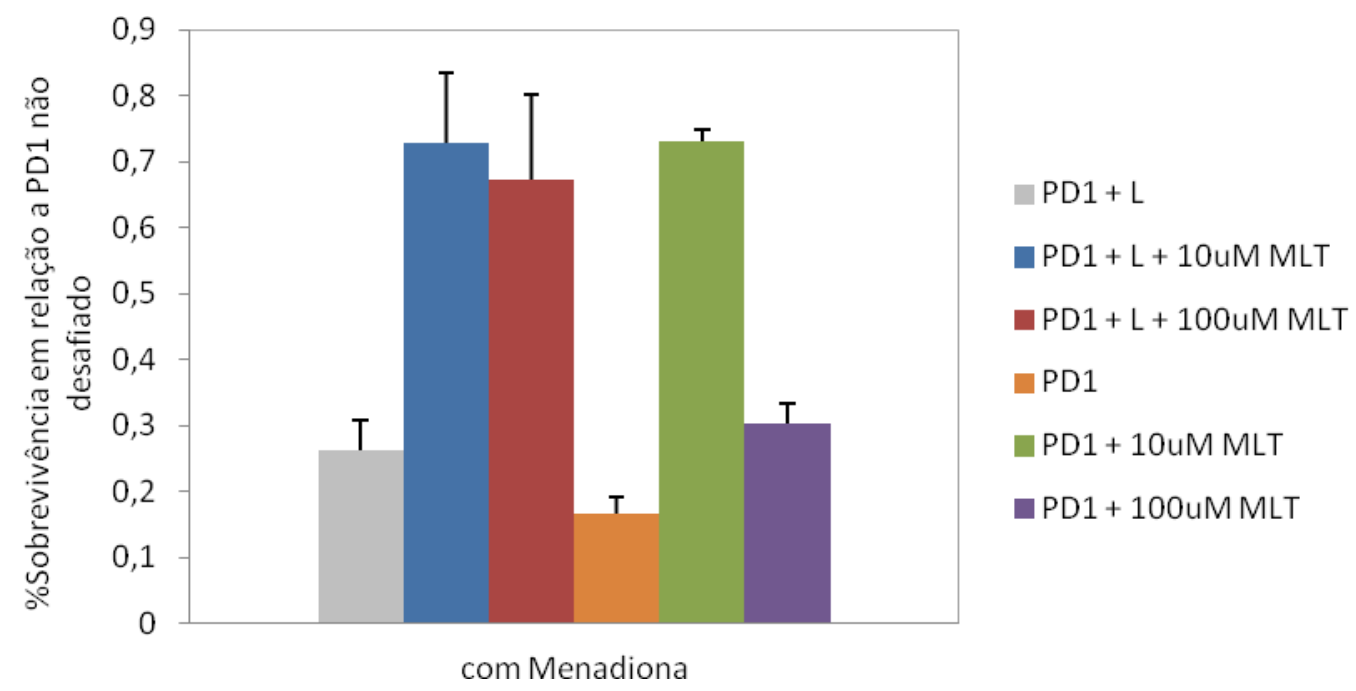

Ao enfrentar o desafio, o crescimento celular, em relação a PD1 sem menadiona (sobrevivência $=1,0$ ), é mais bem recuperado nas leveduras parkinsonianas após tratamento com $10 \mu \mathrm{M}$ melatonina (MLT) $(\mathrm{n}=3)$.

\subsection{Medidas de capacidade respiratória}

4.2.1 $\alpha$-sinucleína diminui atividade do complexo III, que é recuperada por melatonina

Na cadeia transportadora de elétrons mitocondrial de mamíferos, o complexo I (NADHubiquinona oxidorredutase) e o complexo II (succinato-ubiquinona redutase) transferem os elétrons, respectivamente, dos carreadores $\mathrm{NADH}$ e $\mathrm{FADH}_{2}$ para uma coenzima lipossolúvel, 
a coenzima $\mathrm{Q}(\mathrm{CoQ})$, reduzindo-a a $\mathrm{CoQH}_{2}$, que, por sua vez, os passa para o complexo III (ubiquinol - citocromo $c$ oxidorredutase) (revisto em LENAZ et al., 2007). O complexo III possui como centros catalíticos dois citocromos $b$, um citocromo $c 1$ e um centro [2Fe-2S] conhecido como centro de Rieske. A atividade redox do ubiquinol é acoplada à sua protonação e desprotonação que ciclicamente é utilizada pelo complexo III para a passagem de prótons para o espaço intermembrana, com concomitante redução do citocromo $c$ (SARASTE, 1999). Em leveduras, há a diferença de que a NADH - ubiquinona oxidoredutase não forma um grande complexo respiratório (GRANDIER-VAZEILLE et al., 2001).

A atividade do complexo III foi medida conforme descrita em métodos, utilizando 20 $\mu \mathrm{g}$ de proteínas mitocondriais e NADH como substrato. Não houve isolamento do complexo, sendo utilizadas mitocôndrias inteiras, extraídas de meio mínimo com galactose, contendo ou não $10 \mu \mathrm{M}$ melatonina.

Figura 4.14 - Atividade do complexo III (redução de citocromo $c$ ) de mitocôndrias isoladas de W303 (WT) e PD1, suplementadas com $10 \mu \mathrm{M}$ melatonina (MLT) ( $\mu \mathrm{mol}$ cit $c$ reduzido $\left.\bullet \mathrm{min}^{-1} \cdot \mathrm{mg} \operatorname{prot}^{-1}\right)$.

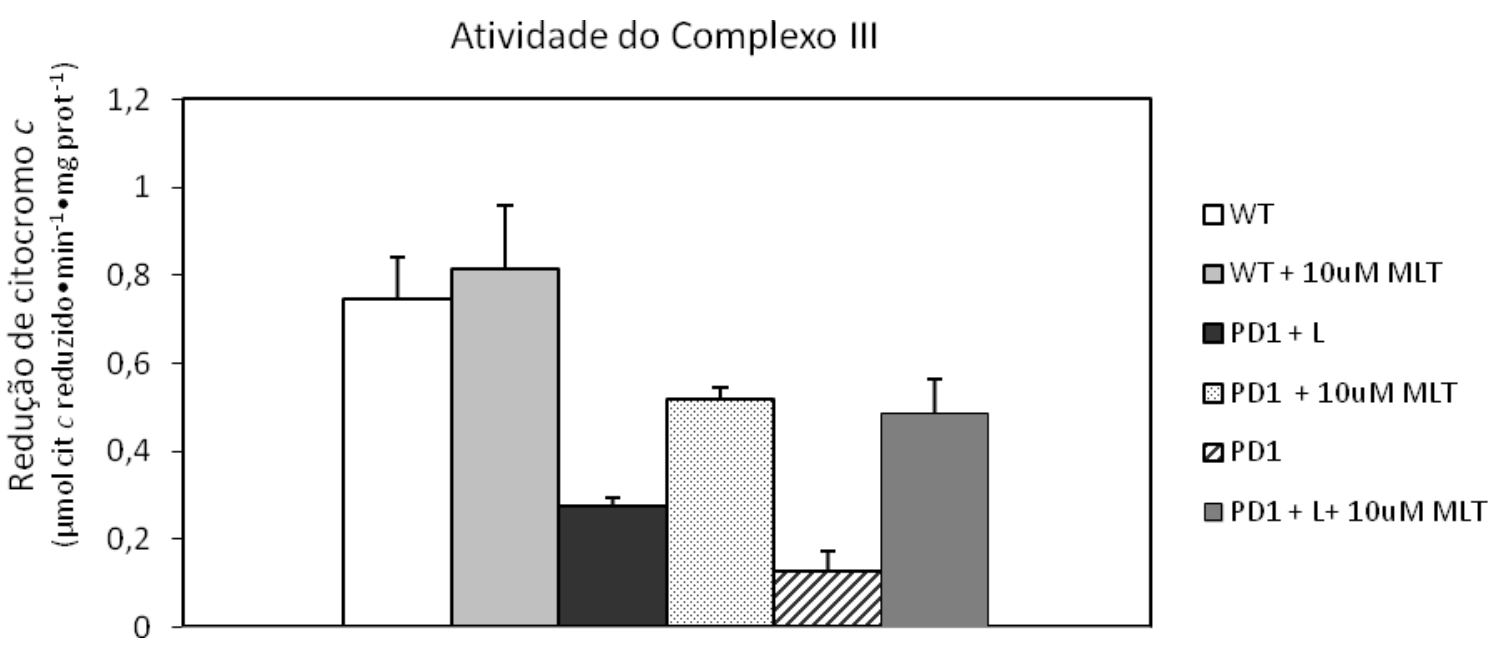

Cresceram-se as células em meio mínimo com galactose para obtenção das mitocôndrias. $\mathrm{O}$ número de cópias do gene $S N C A$ foi modulado pelo crescimento das células em presença de leucina (L) ou em sua ausência, que agravou a toxicidade de $\alpha$-sin.

Observa-se que há uma queda significativa da atividade desse complexo em células expressando $\alpha$-sinucleína ( $p<0,0001$ ), sendo a diminuição mais severa com um aumento no número de cópias do gene $S N C A$. Com a suplementação prévia com melatonina, sua atividade foi parcialmente recuperada $(p<0,0001)$, não havendo diferença significativa em relação ao maior número de cópias de SNCA em PD1 $(p=0,5338)$. Ainda, não há diferença significativa 
de atividade do complexo III para o tratamento com melatonina na linhagem parental (WT, $p=0,658)$. Verifica-se que o efeito protetor de melatonina visto nos experimentos com desafio de menadiona deve-se, ao menos em parte, por sua ação nas mitocôndrias das células parkinsonianas.

4.2.2 Melatonina recupera a atividade do complexo IV de leveduras parkinsonianas

Na mitocôndria, após redução do citocromo $c$ pelo complexo III, os elétrons são transferidos para o complexo IV (citocromo $c$ oxidase), o qual faz a redução eletrônica do oxigênio em água. Ao final, o gradiente de prótons é aproveitado para a síntese de ATP pela ATP-sintase (complexo V), cuja força motriz gerada pela passagem de prótons é utilizada para a fosforilação do ADP em ATP (SARASTE, 1999). É importante, portanto, um correto funcionamento do complexo IV para a correta redução do oxigênio molecular, evitando a produção excessiva de espécies reativas de oxigênio.

Figura 4.15 - Atividade do complexo IV (oxidação de citocromo $c$ reduzido) de mitocôndrias isoladas de W303 (WT) e PD1, suplementadas com $10 \mu \mathrm{M}$ melatonina (MLT) $\left(\right.$ nmol cit $c$ oxidado $\bullet \mathrm{min}^{-1} \cdot \mathrm{mg} \mathrm{prot}^{-1}$ ).

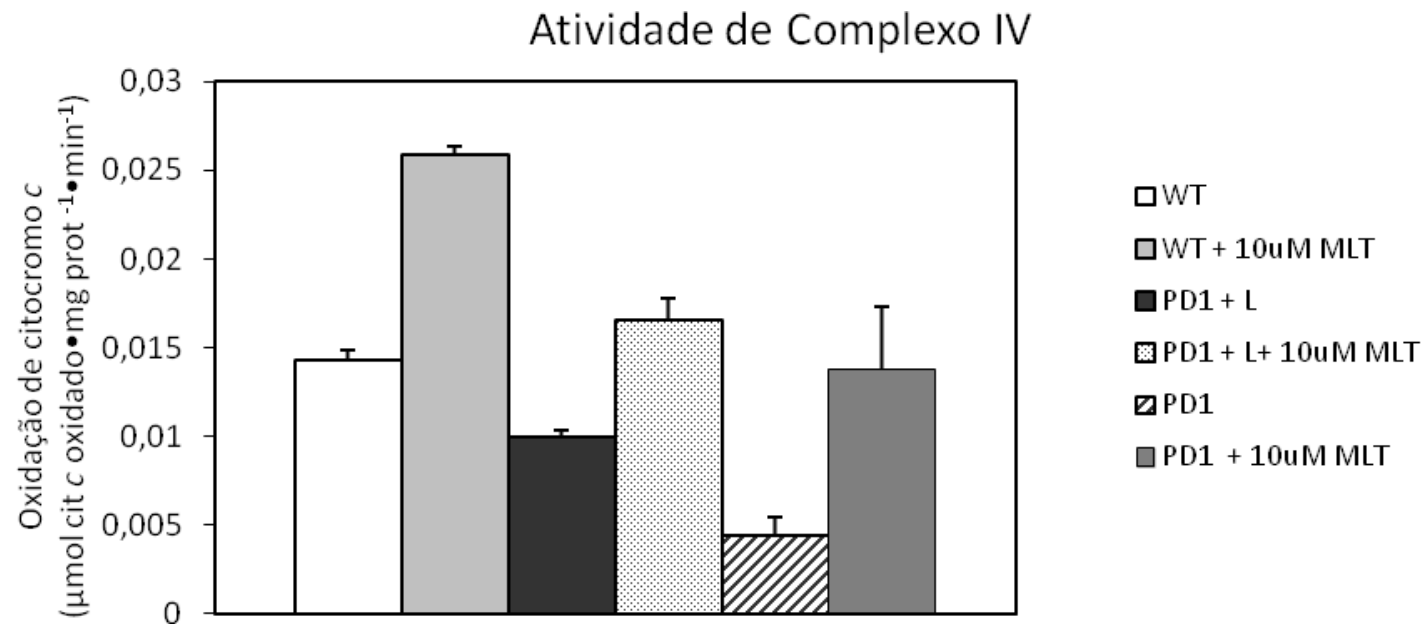

Cresceram-se as células em meio mínimo com galactose para obtenção das mitocôndrias. $\mathrm{O}$ número de cópias do gene $S N C A$ foi modulado pelo crescimento das células em presença de leucina (L) ou em sua ausência, que agravou a toxicidade de $\alpha$-sin.

Observa-se uma diminuição significativa da atividade desse complexo em células expressando $\alpha$-sin $(p<0,0001)$, que é mais severa com um aumento no número de cópias do gene $S N C A$. Com a suplementação prévia com melatonina, sua atividade foi recuperada 
( $p<0,0001)$, não havendo diferença significativa em relação ao maior número de cópias de SNCA em PD1 ( $p=0,4377)$. Interessantemente, a recuperação de PD1 não é estatisticamente diferente da linhagem selvagem não tratada com melatonina (PD1+leucina: $p=0,0586$; PD1: $p=0,0608$. Ainda, observamos um aumento significativo de atividade do complexo IV com o tratamento com melatonina na linhagem parental $(p<0,0001)$. Novamente, pode-se dizer que o efeito protetor antioxidante de melatonina deve-se, em parte, por sua ação nas mitocôndrias das células parkinsonianas.

\subsubsection{Melatonina aumenta o consumo de oxigênio pelas mitocôndrias}

A produção de ATP é essencial para manter os processos celulares que necessitam de aporte energético. A maioria das células mantém o suprimento de ATP pela fosforilação oxidativa mitocondrial, que acopla a oxidação de metabólitos à síntese de ATP a partir do ADP e do fosfato inorgânico. $\mathrm{O}$ consumo de oxigênio é proporcional à taxa de utilização de ATP pelas células, cuja demanda acarreta um aumento na atividade mitocondrial. É, portanto, uma medida importante do estado mitocondrial, pois geralmente reflete a eficiência da respiração celular, relacionada ao correto funcionamento da cadeia transportadora de elétrons.

Figura 4.16 - Oxidação de NADH medida pelo consumo de oxigênio (nmol•mg $\operatorname{prot}^{-1} \cdot \mathrm{min}^{-1}$ ) de mitocôndrias extraídas de W303 (WT) e PD1, suplementadas com $10 \mu \mathrm{M}$ melatonina (MLT).

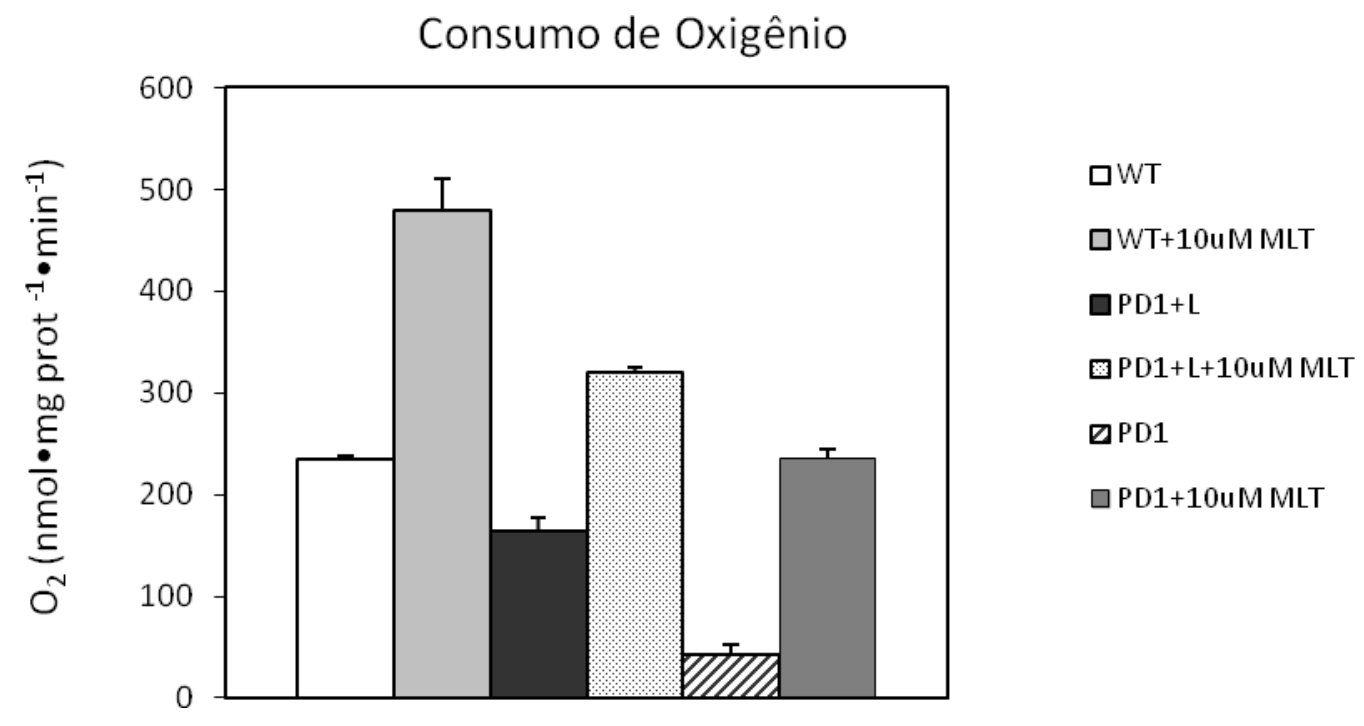

Cresceram-se as células em meio mínimo com galactose para obtenção das mitocôndrias. O número de cópias do gene $S N C A$ foi modulado pelo crescimento das células em presença de leucina (L) ou em sua ausência, que agravou a toxicidade de $\alpha$-sin $(\mathrm{N}=3)$. 
Em relação à linhagem parental, houve uma redução significativa do consumo de oxigênio com a produção de $\alpha$-sin $(p<0,0001)$. Comparando as duas situações de PD1, a redução foi ainda maior com o aumento do número de cópias do gene $S N C A(\mathrm{p}<0,0001)$. Com o tratamento prévio com $10 \mu \mathrm{M}$ melatonina, o consumo de $\mathrm{O}_{2}$ aumentou significativamente para a linhagem parental, o que também foi visto para as duas condições da linhagem PD1 $(\mathrm{p}<0,0001)$. Comparando as amostras independentemente, observa-se a recuperação do consumo de $\mathrm{O}_{2}$ de PD1 com a suplementação com MLT, pois não há diferença significativa entre a linhagem W303 (não suplementada) e a linhagem PD1 tratada, mesmo em relação ao menor ( $\mathrm{p}=0,0248)$ e ao maior ( $\mathrm{p}=0,4823)$ número de cópias. Esse resultado indica uma ação benéfica da melatonina nas mitocôndrias parkinsonianas ao melhorar sua atividade respiratória. 


\section{DISCUSSÃO FINAL}

A levedura Saccharomyces cerevisiae é um organismo modelo interessante para o estudo de diversas citopatologias e, como visto por Outeiro e Lindquist (2003), é extremamente útil para um melhor entendimento da biologia celular envolvendo $\alpha$-sinucleína, apesar de não produzir essa proteína. Assim, construímos linhagens expressando o gene SNCA e vimos que não havia efeito no crescimento, em meio respiratório, quando este gene estava integrado em uma única cópia em seu genoma (figura 4.6), independente do promotor utilizado para expressá-lo, pois não houve diferença significativa nos tempos de geração (tabela 4.1). Deficiência significativa de crescimento em meio respiratório só foi observada com a utilização vetor epissomal pEG(KG)-SNCA (DIXON et al., 2005) como melhor ilustrado na figura 4.2, um primeiro indício de redução na atividade respiratória. De fato, o crescimento reduzido, em meio seletivo para atividade respiratória, deve-se à ativação da expressão do gene SNCA em galactose, pois a transformação de leveduras com o vetor pEG(KG) vazio não acarretou diferença significativa em seu crescimento em relação à linhagem parental (figura 4.10 e tabela 4.4).

Como visto na literatura especializada, o estresse oxidativo é uma característica da doença de Parkinson. Assim, buscamos realizar desafios com oxidantes para analisar a resposta de células produtoras de $\alpha$-sin frente ao estresse oxidativo induzido. Primeiramente, realizamos desafios com peróxido de hidrogênio, espécie reativa de oxigênio (ROS) não radicalar, resultado da dismutação do ânion radical superóxido (BOVERIS; CHANCE, 1973). A produção de $\mathrm{H}_{2} \mathrm{O}_{2}$ pode levar a danos através da geração de radical hidroxila $\left(\mathrm{OH}^{*}\right)$, altamente reativo, através de reações de Fenton. No entanto, esses desafios não apresentaram diferenças significativas entre W303 e PD1. Decidimos, então, nos concentrar em outro agente oxidante, a menadiona, que apresentou maior variação entre as linhagens.

A menadiona é uma cetona policíclica aromática capaz de gerar ROS no ciclo redox (CRIDDLE et al., 2006). Em baixas concentrações, pode ativar a transcrição de genes relacionados ao controle do estresse oxidativo. Mas em concentrações altas, como a utilizada em nossos experimentos, menadiona gera grande estresse oxidativo associado a danos ao DNA mitocondrial, o que induz morte celular (CHUANG et al., 2002). Na figura 4.3, observa-se que para a linhagem W303, crescida tanto em meio mínimo com glicose quanto com galactose, o decréscimo da viabilidade após o desafio com menadiona é similar ( $p=0,0941)$, sendo este significativo quando comparado à condição controle, sem o agente 
oxidante $(p<0,0001)$. Como o decréscimo é similar para células crescidas em glicose e em galactose, para efeito das análises estatísticas, serão consideradas somente as células crescidas em galactose, situação em que a expressão do gene $S N C A$ está ativada. Com a produção de $\alpha$ sin em galactose, observou-se uma significativa diminuição da viabilidade celular após o desafio com menadiona, agravando a toxicidade de $\alpha$-sin. Ensaios de crescimento por diluições seriadas (figura 4.4) mostram que a produção de $\alpha$-sin acarreta uma diminuição crescimento celular em meio seletivo para a atividade respiratória, indicando comprometimento da função mitocondrial, fenótipo agravado com o desafio com o oxidante. Interessantemente, em termos estatísticos, observamos que o desafio da linhagem parental com menadiona produziu um fenótipo semelhante à simples ativação da transcrição do gene SNCA na linhagem PD1, pois não houve diferença significativa de sobrevivência entre essas condições. Dessa forma, há indícios que a ativação da expressão do gene SNCA produza estresse oxidativo estatisticamente semelhante ao desafio de células W303 com menadiona.

Como observado por Junn e Mouradian em 2002, um aumento dos níveis de SNCA está relacionado com um aumento nos níveis de ROS intracelulares, o que pode explicar o fenótipo observado em meio respiratório quando a expressão desse gene estava ativada. Dessa forma, neutralizar ROS pode ser uma alternativa para tratar as células parkinsonianas. Assim, buscamos caracterizar a resposta de $S$. cerevisiae, expressando os genes de via biossintética da melatonina, um hormônio produzido pela glândula pineal de vertebrados que possui propriedades antioxidantes.

Em um primeiro momento, testes de crescimento em meio seletivo para a atividade respiratória mostraram não haver diferença significativa no desempenho de células W303 e MLT10, mesmo com a ativação da transcrição dos genes da via da melatonina (figura 4.5), pois os tempos de geração foram similares (tabela 4.3). Na figura 4.6, observa-se que, somente com a ativação da transcrição dos genes dessa via houve uma melhora significativa na viabilidade celular após desafio com $\mathrm{H}_{2} \mathrm{O}_{2}$. Essa linhagem celular também passou por um desafio com menadiona (figura 4.7), e, de maneira similar, somente com a ativação da transcrição gênica houve uma melhora significativa em sua viabilidade. No entanto, a resposta dessa linhagem aos antioxidantes foi diferente: observa-se que o tratamento com peróxido de hidrogênio ocasionou um estresse oxidativo mais brando, com viabilidade celular da linhagem parental ou de MLT10 crescida em glicose em torno de 60\%; para as células desafiadas com menadiona, a viabilidade dessas linhagens foi menor, em torno de $20 \%$, indicando que o tratamento com o oxidante foi mais agressivo. Como pode ser observada qualitativamente nas 
diluições seriadas, a expressão de MLT10 melhorou o desempenho respiratório da linhagem, mesmo quando desafiada com menadiona. De qualquer forma, a recuperação com a expressão de MLT10 foi significativa.

Diversas evidências mostram uma relação entre melatonina e PD. Inicialmente, Sandyk (1990) detectou uma diminuição da atividade da glândula pineal e, assim, dos níveis de MLT no plasma de pacientes com PD, o que poderia estar relacionado aos distúrbios do sono frequentemente observados nesses pacientes, como RBD (do inglês, rapid eye-moviment (REM) sleep behaviour disorder). $\mathrm{O}$ aparecimento de $\mathrm{RBD}$, caracterizada por atividades motoras proeminentes durante o estágio REM do sono (SCHENCK; MAHOWALD, 2002), parece estar associado a sinucleinopatias após vários anos (MAHOWALD; SCHENCK; BORNEMANN, 2007), como PD. Adicionalmente, MLT inibe, in vitro, os efeitos próoxidantes de Levodopa (L-dopa), droga comumente utilizada no tratamento de PD (MILLER; SELHUB; JOSEPH, 1996). A administração de MLT (aguda ou crônica) previne a peroxidação lipídica no cérebro de camundongos tratados com MPTP, diminuindo a morte de neurônios nigrais (JIN et al., 1990). Dessa forma, buscamos utilizar a produção de melatonina para neutralizar a toxicidade observada com a produção de $\alpha$-sin por S.cerevisiae, modelo de PD. Como não tivemos sucesso na detecção da expressão dos genes necessários para a síntese de melatonina, optamos por realizar sua suplementação farmacológica.

Segundo Chakravarty e Rizvi (2011), os niveis fisiológicos de melatonina no plasma humano estão em torno de $10 \mathrm{nM}$. No entanto, alguns dos efeitos terapêuticos são apenas

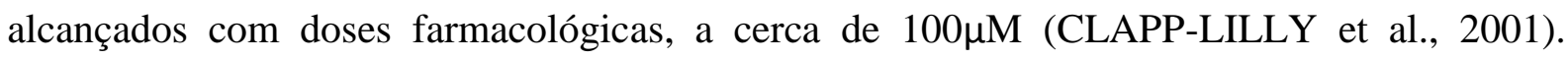
Suplementando a linhagem PD1 com $10 \mu \mathrm{M}$ MLT em seu pré-crescimento, observamos que essa concentração foi mais eficiente em diminuir a toxicidade de $\alpha$-sin do que $100 \mu \mathrm{M}$ MLT (figura 4.9). Visando quantificar essa melhora, o crescimento, em meio mínimo seletivo para atividade respiratória, foi monitorado por 92 h após pré-crescimento com $10 \mu \mathrm{M}$ MLT em galactose (figura 4.10). Observamos que não havia diferença significativa entre os tempos de geração das linhagens parentais, o que foi confirmado com o teste $T$ de Student. Para as linhagens parkinsonianas, observou-se um aumento significativo nos tempos de geração (tabela 4.4) em relação às linhagens parentais, sendo este aumento maior com o aumento do número de cópias do gene $S N C A$. Ainda, observou-se que o pré-tratamento com melatonina $(10 \mu \mathrm{M})$ foi suficiente para diminuir significativamente o tempo de geração $(p<0,0001)$, o que significa que a população de células parkinsonianas cresce significativamente mais quando protegida pela melatonina. 
Esses experimentos fornecem fortes indícios de proteção de leveduras parkinsonianas a partir da suplementação farmacológica com melatonina, mesmo que não restaure completamente a viabilidade aos níveis parentais. Realizamos, então, desafios com menadiona para verificar se o pré-tratamento com melatonina seria suficiente para proteger as leveduras contra o estresse oxidativo que agravaria ainda mais a toxicidade de $\alpha$-sin. Mais uma vez, a simples produção de $\alpha$-sin na linhagem parkinsoniana (PD1) reduz significativamente sua sobrevivência em relação à linhagem parental, sendo essa redução semelhante à redução vivenciada pela linhagem parental quando desafiada com menadiona (figura 4.11). O prétratamento com MLT aumentou a sobrevivência da linhagem parental desafiada, que chegou a níveis similares ao da situação controle. PD1 apresenta um agravamento no decréscimo da sobrevivência quando submetida ao estresse oxidativo da menadiona, sendo ele significativamente maior quando há um maior número de cópias do gene SNCA em PD1 sem leucina $(p<0,0001)$. Há uma significativa recuperação, ainda que parcial, dessa linhagem com o pré-tratamento com melatonina independente do número de cópias do gene $S N C A$ ( $p<0,0001)$, chegando a níveis similares da linhagem parental desafiada (PD1+leucina: $p=0,0011$; PD1: $p=0,0068$ ). No entanto, ao considerar a linhagem parental tratada com melatonina, a recuperação de PD1 não é tão eficiente, dado o grande aumento no estresse oxidativo a partir do desafio, o que pode ser visto nas análises qualitativas de diluições seriadas na figura 4.12. Verificamos, também, que, realmente, a dose de $10 \mu \mathrm{M}$ melatonina exerce um maior efeito protetor às leveduras produtoras de $\alpha$-sin submetidas ao estresse com menadiona, em relação aos respectivos controles parkinsonianos, indicando que esta dose seria mais promissora para seu tratamento que a dose de $100 \mu \mathrm{M}$ (figura 4.13). O efeito observado pelas diferentes doses utilizadas poderia ser resultado do balanço entre os efeitos pró e antioxidantes da MLT de acordo com o genótipo da linhagem PD1: com o maior número de cópias de $S N C A$, há uma maior toxicidade de $\alpha$-sin e, com a menor dose de MLT $(10 \mu \mathrm{M})$, a sinalização antioxidante seria maior que a pró-oxidante, conferindo aumento da viabilidade celular, o que não aconteceria com $100 \mu \mathrm{M}$ MLT (VAN RAAMSDONK; HEKIMI, 2012).

Todos os indícios de crescimento em meio seletivo para atividade respiratória apontam para disfunção mitocondrial de S.cerevisiae, causada pelos altos níveis de $\alpha$-sin, o que tem sido observado em diversos estudos: a $\alpha$-sin aumenta os níveis de ROS produzido pela mitocôndria, diminuindo estabilidade de seu DNA, o que diminuiria a eficiência da respiração celular e da fosforilação oxidativa, que, por sua vez, aumentaria os níveis de ROS, 
constituindo um ciclo de retroalimentação positiva (TRACHOOTHAM; ALEXANDRE; HUANG, 2009). Existe uma correlação entre PD e disfunção do complexo I e estresse oxidativo em mamíferos, apesar de não haverem experimentos mencionando as NADH desidrogenases de S.cerevisiae. Em modelos parkinsonianos, a toxicidade de $\alpha$-sin é semelhante à induzida por rotenona, ou seja, através da inibição do complexo I no tecido cerebral (BETARBET et al., 2000), já que essa substância induz agregação de $\alpha$-sin semelhante aos casos de PD familiar (SHERER et al., 2002). Sherer e colaboradores (2003b) mostraram que essa inibição é específica para o complexo I de eucariotos superiores: células de neuroblastoma transfectadas com a $\mathrm{Nd} 1 \mathrm{p}$ de S.cerevisiae não apresentaram disfunção mitocondrial, dano oxidativo elevado e morte celular, característicos desse modelo de PD. Pode-se inferir que, provavelmente, as NADH desidrogenases de levedura não seriam alvo de $\alpha$-sin, o que, obviamente, necessita de maiores estudos.

Ainda, além do complexo I, o complexo III é um dos principais centros de geração de ROS (SUN; TRUMPOWER, 2003; TURRENS, 2003;). Em S. cerevisiae, as NADH desidrogenases externas também estão envolvidas nesse processo (FANG; BEATTIE, 2003). Em modelo S. cerevisiae para doença de Huntington, Solans e colaboradores (2006) observaram, especificamente, diminuição da atividade dos complexos II/III, o que também ocorre nos estágios iniciais de PD em pacientes não tratados (HAAS et al., 1995). Com a diminuição de sua atividade, a coenzima $Q$ parcialmente reduzida poderia interagir mais facilmente com o $\mathrm{O}_{2}$ da matriz mitocondrial, reduzindo-o de maneira incompleta, o que produziria ROS.

Sendo assim, quantificamos a atividade do complexo III de mitocôndrias extraídas de células crescidas em meio mínimo com galactose e suplementadas, ou não, com $10 \mu \mathrm{M}$ melatonina (figura 4.13). O crescimento em galactose, além de estimular a biogênese mitocondrial, permitiu a expressão e produção de $\alpha$-sin pela linhagem PD1. Obversamos que não há diferença significativa de atividade do complexo III para o tratamento com melatonina na linhagem parental (WT, $p=0,658)$. Assim como os resultados de Solan e colaboradores (2006) para o modelo da doença de Huntington, observamos uma queda significativa da atividade desse complexo em células expressando $\alpha$-sinucleína $(p<0,0001)$, sendo a diminuição mais severa com um aumento no número de cópias do gene $S N C A$. Com a suplementação prévia com melatonina, sua atividade foi parcialmente recuperada $(p<0,0001)$, não havendo diferença significativa em relação ao maior número de cópias de SNCA em PD1 $(p=0,5338)$. Aliados à recuperação parcial do crescimento em meio seletivo para atividade 
respiratória com a suplementação com MLT (figura 4.10 e tabela 4.4), a qual possui efeitos antioxidantes, estes resultados indicam que a disfunção mitocondrial não é o único efeito citotóxico causado por $\alpha$-sin.

Elkon e colaboradores (2002) mostraram que $\alpha$-sin interage com o complexo IV e, em camundongos expressando formas mutantes de $\alpha$-sin humana, há uma redução significativa de sua atividade (MARTIN et al., 2006). Após passarem pelos complexos respiratórios, os elétrons passam, então, para o complexo IV que oxida o citocromo $c$ reduzido e reduz o $\mathrm{O}_{2}$ a $\mathrm{H}_{2} \mathrm{O}$ (SARASTE, 1999). É importante, portanto, um correto funcionamento do complexo IV para a correta redução do oxigênio molecular, evitando a produção excessiva de espécies reativas de oxigênio.

Realizamos, então, medidas de atividade do complexo IV (figura 4.15) e observamos que há uma diminuição significativa da atividade desse complexo em células expressando $\alpha$ sinucleína $(p<0,0001)$, mais acentuada com um aumento no número de cópias do gene SNCA. Com a suplementação prévia com $10 \mu \mathrm{M}$ melatonina, sua atividade foi recuperada $(p<0,0001)$, não havendo diferença significativa em relação ao maior número de cópias de SNCA em PD1 ( $p=0,4377)$. Interessantemente, a recuperação de PD1 não é estatisticamente diferente da linhagem selvagem não tratada com melatonina (PD1+leucina: $p=0,0586$; PD1: $p=0,0608)$. Observamos, ainda, que o tratamento com melatonina aumentou significativamente a atividade do complexo IV da linhagem parental. Novamente, pode-se dizer que o efeito protetor antioxidante de melatonina deve-se, em parte, por sua ação nas mitocôndrias das células parkinsonianas.

Por essas duas medidas de atividade, pode-se dizer que $\alpha$-sin causa disfunção mitocondrial em S.cerevisiae, a qual poderia ser causada pela desestabilização do DNA mitocondrial, apesar de não termos observados alterações estatisticamente significativas da frequência de formação de petites. A redução da atividade dos complexos mitocondriais pode ter sido causada por uma inibição desses complexos, por uma redução da expressão de suas subunidades ou até mesmo pela diminuição da formação desses complexos ou de sua organização em supercomplexos, o que deverá ser confirmado em estudos posteriores. Como visto em S. cerevisiae para a doença de Huntington, há diminuição de subunidades dos complexos II+III, particularmente sensíveis ao estresse oxidativo devido à presença de centros ferro-enxofre em seus sítios catalíticos, o que impede a montagem correta desses complexos nas mitocôndrias, culminando na redução específica de sua atividade (SOLANS et al., 2006). Alternativamente, $\alpha$-sin poderia interagir com as membranas mitocondriais promovendo a 
desestabilização e alterando a função dos complexos mitocondriais aqui analisados. A diminuição da atividade desses complexos pode aumentar ainda mais a produção de ROS e contribuir para agravar as disfunção mitocondrial e comprometer a produção de ATP celular. De fato, em culturas de neurônios expressando formas mutantes de $\alpha$-sin (A53T e E46K), há uma queda na fosforilação oxidativa e no consumo de oxigênio que precede neurodegeneração (NAKAMURA et al., 2011). Como essas mutações estão associadas ao desenvolvimento de PD familiar de maneira semelhante ao aumento do número de cópias do gene $S N C A$, o consumo de $\mathrm{O}_{2}$ pelas mitocôndrias extraídas de células PD1 também foi avaliado (figura 4.16).

Em relação à linhagem parental, houve uma redução significativa do consumo de oxigênio com a produção de $\alpha$-sin $(p<0,0001)$. Comparando as duas situações de PD1, a redução foi ainda maior com o aumento do número de cópias do gene $S N C A$ ( $\mathrm{p}<0,0001)$, quando as células cresceram na ausência de leucina. Com o tratamento prévio com $10 \mu \mathrm{M}$ melatonina, o consumo de $\mathrm{O}_{2}$ aumentou significativamente para a linhagem parental ( $\mathrm{p}<0,0001)$, dobrando-o. Comparando as amostras independentemente, observa-se a recuperação do consumo de $\mathrm{O}_{2}$ de PD1 com a suplementação com MLT, pois não há diferença significativa em relação à linhagem W303 não tratada. A recuperação de PD1 foi significativa mesmo em relação ao menor $(\mathrm{p}=0,0248)$ e ao maior $(\mathrm{p}=0,4823)$ número de cópias de SNCA.

Esses resultados indicam uma ação benéfica da melatonina nas mitocôndrias de leveduras parkinsonianas ao melhorar sua eficiência respiratória, medida através das atividades do complexo III e IV e do consumo de oxigênio. O aumento no consumo de $\mathrm{O}_{2}$ das células PD1, aliado a uma melhora visível no crescimento em meio respiratório, parece resultar de uma melhora geral da função mitocondrial, inclusive na situação de estresse oxidativo causado por menadiona. Como os primeiros sintomas de PD começam a aparecer quando já há grande perda neuronal (revisto por Mayo et al., 2005), a administração de antioxidantes, como a MLT, deve ser iniciada quando são detectadas alterações que frequentemente precedem os sintomas inicias da doença, como RBD ou de alterações olfativas, evitando, assim, a morte de neurônios dopaminérgicos. Ainda, a melhora aqui observada com o tratamento farmacológico de MLT pode ser promissora também nos estágios iniciais de PD, indicando que a substância poderia ser utilizada como um fármaco auxiliar no tratamento da patologia ou, em casos de PD familiar, antes de sintomas aparecerem. 


\section{CONCLUSÕES}

- Saccharomyces cerevisiae se mostrou um bom modelo para o estudo de PD e da terapia com melatonina;

- A expressão de $\alpha$-sin é tóxica para S.cerevisiae: as leveduras apresentaram deficiência no crescimento em meio respiratório decorrente da redução da atividade dos complexos respiratórios III e IV e do consumo de oxigênio;

- A toxicidade de $\alpha$-sin é semelhante à toxicidade de menadiona;

- Melatonina é eficaz em restaurar a sobrevivência de células parentais e, parcialmente, a de células parkinsonianas, desafiadas com menadiona;

- O pré-tratamento com melatonina foi eficaz em restaurar os padrões respiratórios de leveduras produtoras de $\alpha$-sin e em elevar a atividade respiratória da linhagem parental;

- O tratamento com melatonina, nos estágios iniciais ou que precedem PD, associado a outros medicamentos, como L-dopa, pode ser promissor para tratar o componente mitocondrial da doença. 


\section{REFERÊNCIAS $^{1}$}

ACUÑA-CASTROVIEJO, D.; CARRETERO, M.; DOERRIER, C.; LÓPEZ, L. C.; GARCÍA-CORZO, L.; TRESGUERRES, J. A.; ESCAMES, G. Melatonin protects lung mitochondria during aging. Age, v. 34, p. 681-692, 2012.

ALBERTI, C. Melatonin: the first hormone isolated from the pineal body. Farmaco. Sci., v. 13 , n. 8, p. 604-605, 1958.

ALBERTYN, J.; HOHMANN, S.; THEVELEIN, J. M.; PRIOR, B. A. GPD1, which encodes glycerol-3-phosphate dehydrogenase, is essential for growth under osmotic stress in Saccharomyces cerevisiae, and its expression is regulated by the high-osmolarity glycerol response pathway. Mol. Cell. Biol., v. 14, n. 6, p. 4135-4144, 1994.

AUSUBEL, F. M.; BRENT, R.; KINGSTON, R. E.; MOORE, D. D.; SEIDMAN, J. G.; SMITH, J. A.; STRUHL, K. Current protocols in molecular biology. New York: Gene Publishers Association and Wiley \& Sons, 1987. 5030 p.

ALBARRÁN, M. T.; LÓPEZ-BURILLO, S.; PABLOS, M. I.; REITER, R. J.; AGAPITO, M. $T$. Endogenous rhythms of melatonin, total antioxidant status and superoxide dismutase activity in several tissues of chick and their inhibition by light. J. Pineal Res., v. 30, n. 4, p. 227-233, 2001.

ALIM, M. A.; HOSSAIN, M. S.; ARIMA, K.; TAKEDA, K.; IZUMIYAMA, Y.; NAKAMURA, M.; KAJI, H.; SHINODA, T.; HISANAGA, S.; UÉDA, K. Tubulin seeds alpha-synuclein fibril formation. J. Biol. Chem., v. 277, n. 3, p. 2112-2117, 2002.

ALIM, M. A.; MA, Q. L.; TAKEDA, K.; AIZAWA, T.; MATSUBARA, M.; NAKAMURA, M.; ASADA, A.; SAITO, T.; KAJI, H.; YOSHII, M.; HISANAGA, S.; UÉDA, K. Demonstration of a role for alpha-synuclein as a functional microtubule-associated protein. $\mathbf{J}$. Alzheimers Dis., v. 6, n. 4, p. 435-442, 2004.

ALLEN, J.F.; RAVEN, J.A. Free radical-induced mutation vs redox regulation: costs and benefits of genes in organelles. J. Mol. Evol., v. 42, p. 482-492, 1996.

ANTOLIN, I.; RODRÍGUEZ, C.; SAINZ, R. M.; MAYO, J. C.; URÍA, H.; KOTLER, M. L.; RODRÍGUEZ-COLUNGA, M. J.; TOLIVIA, D.; MENÉNDEZ-PELÁEZ, A. Neurohormone melatonin prevents cell damage: effect on gene expression for antioxidant enzymes. FASEB J., v. 10, n. 8, p. 882-890, 1996.

AULUCK, P. K.; CARAVEO, G.; LINDQUIST, S. $\alpha$-Synuclein: membrane interactions and toxicity in Parkinson's disease. Annu. Rev. Cell Dev. Biol., v. 26, p. 211-233, 2010.

AYALA, A.; VENERO, J. L.; CANO, J.; MACHADO, A. Mitochondrial toxins and neurodegenerative diseases. Front Biosci., v. 12, p. 986-1007, 2007.

\footnotetext{
${ }^{1}$ De acordo com:

ASSOCIAÇÃO BRASILEIRA DE NORMAS TÉCNICAS. NBR 6023: Informação e documentação: referências: elaboração. Rio de Janeiro, 2002.
} 
AXELROD, J. Noradrenaline: fate and control of its biosynthesis. Science, v. 173, p. 598606, 1971.

BAKKER, B.; OVERKAMP, K.; van MARIS, A. J.; KÖTTER, P.; LUTTIK, M.; VAN DIJKEN, J. P.; PRONK, J. T. Stoichiometry and compartmentation of NADH metabolism in Saccharomyces cerevisiae. FEMS Microbiol. Rev., v. 25, n. 1, p. 15-37, 2001.

BARRIENTOS, A. Yeast models of human mitochondrial diseases. IUBMB Life, v. 55, p, 83-97, 2003.

BASSEL, J.; MORTIMER, R. Genetic order of the galactose structural genes in Saccharomyces cerevisiae. J. Bacteriol., v. 108, n. 1, p. 179-183, 1971.

BETARBET, R.; SHERER, T. B.; MACKENZIE, G.; GARCIA-OSUNA, M.; PANOV, A. V.; GREENAMYRE, J. T. Chronic systemic pesticide exposure reproduces features of Parkinson's disease. Nat. Neurosci., v. 3, n. 12, p. 1301-1306, 2000.

BIERE, A. L.; WOOD, S. J.; WYPYCH, J.; STEAVENSON, S.; JIANG, Y.; ANAFI, D.; JACOBSEN, F. W.; JAROSINSKI, M. A.; WU, G. M.; LOUIS, J. C.; MARTIN, F.; NARHI, L. O.; CITRON, M. Parkinson's disease-associated $\alpha$-synuclein is more fibrillogenic than $\beta$ and $\gamma$-synuclein and cannot cross-seed its homologs. J. Biol. Chem., v. 275, p. 34574-34579, 2000 .

BIRNBOIM, H. C.; DOLLY, J. A rapid alkaline extraction procedure for screening recombinant plasmid DNA. Nucleic Acids Res., v. 7, n. 6, p. 1513-1523, 1979.

BLESA, J.; PHANI, S.; JACKSON-LEWIS, V.; PRZEDBORSKI, S. Classic and new animal models of Parkinson's disease. J. Biomed. Biotechnol., v. 2012, ID: 845618, 2012. 10 p.

BOEVE, B. F. The multiple phenotypes of corticobasal syndrome and corticobasal degeneration: implications for further study. J. Mol. Neurosci., v. 2, n. 3, p. 350-353, 2011.

BONINI, N. M.; GIASSON, B. I. Snaring the function of alpha-synuclein. Cell, v. 123, n. 3, p. 359-361, 2005.

BORSOOK, D.; UPADHYAY, J.; CHUDLER, E. H.; BECERRA, L. A key role of the basal ganglia in pain and analgesia--insights gained through human functional imaging. Mol. Pain, v. 13, p. 6-27, 2010.

BOVERIS, A.; CHANCE, B. The mitochondrial generation of hydrogen peroxide. General properties and effect of hyperbaric oxygen. Biochem J., v. 134, p. 707-716, 1973.

BRAAK, H.; DEL TREDICI, K.; RÜB, U.; DE VOS, R. A.; JANSEN STEUR, E. N.; BRAAK, E. Staging of brain pathology related to sporadic Parkinson's disease. Neurobiol. Aging, v. 24, n. 2, p.197-211, 2003.

CASTRO, F. A. V.; MARIANI, D.; PANEK, A. D.; ELEUTHERIO, E. C. A.; PEREIRA, M. D. Cytotoxicity Mechanism of Two Naphthoquinones (Menadione and Plumbagin) in Saccharomyces cerevisiae. PLoS ONE, v. 3, e 3999, 2008. 
CHAKRAVARTY, S.; RIZVI, S.I. Day and night GSH and MDA levels in healthy adults and effects of different doses of melatonin on these parameters. Int. J. Cell Biol., v. 2011, ID: 404591, 2011. 5 p.

CHARTIER-HARLIN， M. C.; KACHERGUS， J.; ROUMIER， C.; MOUROUX, V.; DOUAY, X.; LINCOLN, S.; LAVECQUE, C.; LARVOR, L.; ANDRIEUX, J.; HULIHAN, M.; WAUCQUIER, N.; DEFEBVRE, L.; AMOUYEL, P.; FARRER, M.; DESTEÉ, A. $\alpha-$ Synuclein locus duplication as a cause of familial Parkinson's disease. Lancet, v. 364, n. 9440, p. 1167-1169, 2004.

CHEN, X. J.; BUTOW, R. A. The organization and inheritance of the mitochondrial genome. Nat. Genet., v. 6, p. 815-825, 2005.

CHERNOMORDIK, L.; KOZLOV, M. M.; ZIMMERBERG, J. Lipids in biological membrane fusion. J. Membr. Biol., v. 146, n. 1, p. 1-14, 1995.

CHUANG, Y. Y.; CHEN, Y.; GADISETTI; CHANDRAMOULI, V. R.; COOK, J. A.; COFFIN, D.; TSAI, M. H.; DEGRAFF, W.; YAN, H.; ZHAO, S.; RUSSO, A.; LIU, E. T.; MITCHELL, J. B. Gene expression after treatment with hydrogen peroxide, menadione, or tbutyl hydroperoxide in breast cancer cells. Cancer Res., v. 62, p. 6246-6254, 2002.

CLAPP-LILLY, K. L.; SMITH, M. A.; PERRY, G.; HARRIS, P. L.; ZHU, X.; DUFFY, L. K. Melatonin acts as antioxidant and pro-oxidant in an organotypic slice culture model of Alzheimer's disease. Neuroreport, v. 12, p. 1277-1280, 2001.

CLAYTON, D. F.; GEORGE, J. M. The synucleins: a family of proteins involved in synaptic function, plasticity, neurodegeneration and disease. Trends Neurosci., v. 21, p. 249-254, 1998.

CONTI, A.; CONCONI, S.; HERTENS, E.; SKWARLO-SONTA, K.; MARKOWSKA, M.; MAESTRONI, J. M. Evidence for melatonin synthesis in mouse and human bone marrow cells. J. Pineal Res., v. 28, p. 193-202, 2000.

CONWAY, K. A.; ROCHET, J. C.; BIEGANSKI, R. M.; LANSBURY JR, P. T. Kinetic stabilization of the $\alpha$-synuclein protofibril by a dopamine- $\alpha$-synuclein adduct. Science, v. 294, n. 5545, p. 1346-1349, 2001.

COOPER, A.; GITLER, A. D.; CASHIKAR, A.; HAYNES, C. M.; HILL, K. J.; BHULLAR, B.; LIU, K.; XU, K.; STRATHEARN, K. E.; LIU, F.; CAO, S.; CALDWELL, K. A.; CALDWELL, G. A.; MARSISCHKY, G.; KOLODNER, R. D.; LABAER, J.; ROCHET, J. C.; BONINI, N. M.; LINDQUIST, S. Alpha-synuclein blocks ER-golgi traffic and Rab1 rescues neuron loss in Parkinson's models. Science, v. 313, n. 5785, p. 324-328, 2006.

CRIDDLE, D. N.; GILLIES, S.; BAUMGARTNER-WILSON, H. K.; JAFFAR, M.; CHINJE, E. C.; PASSMORE, S.; CHVANOV, M.; BARROW, S.; GERASIMENKO, O. V.; TEPIKIN, A. V.; SUTTON, R.; PETERSEN, O. H. Menadione-induced reactive oxygen species generation via redox cycling promotes apoptosis of murine pancreatic acinar cells. $\mathbf{J}$. Biol. Chem., v. 281, p. 40485-40492, 2006.

CROCKER, A. D. Dopamine - mechanisms of action. Aust. Prescr., v. 17, p. 17-21, 2004. 
DAVIDSON, W. S.; JONAS, A.; CLAYTON, D. F.; GEORGE, J. M. Stabilization of $\alpha-$ synuclein secondary structure upon binding to synthetic membranes. J. Biol. Chem., v. 273, p. 9443-9449, 1998.

DEVI, L.; RAGHAVENDRAN, V.; PRABHU, B. M.; AVADHANI, N. G.; ANANDATHEERTHAVARADA, H.K. Mitochondrial import and accumulation of $\alpha$ synuclein impair complex I in human dopaminergic neuronal cultures and Parkinson disease brain. J. Biol. Chem., v. 283, n. 14, p. 9089-9100, 2008.

DE VRIES, S.; MARRES, C. A. M. The mitochondrial respiratory chain of yeast. Structure and biosynthesis and the role in cellular metabolism. Biochim. Biophys. Acta, v. 895, p. $205-$ 239, 1987.

DIXON, C.; MATHIAS, N.; ZWEIG, R. M.; DAVIS, D. A.; GROSS, D. S. alpha-Synuclein targets the plasma membrane via the secretory pathway and induces toxicity in yeast. Genetics, v. 170, p. 47-59, 2005.

DOLEZAL, P.; LIKIC, V.; TACHEZY, J.; LITHGOW, T. Evolution of the molecular machines for protein import into mitochondria. Science, v. 313, p. 314-318, 2006.

ELKON, H.; DON, J.; MELAMED, E.; ZIV, I.; SHIRVAN, A.; OFFEN, D. Mutant and wildtype alpha-synuclein interact with mitochondrial cytochrome $C$ oxidase. J. Mol. Neurosci., v. 18, p. 229-238, 2002.

ELIEZER, D.; KUTLUAY, E.; BUSSEL JR, R.; BROWNE, G. Conformational properties of $\alpha$-synuclein in its free and lipid-associated states. J. Mol. Biol., v. 307, p. 1061-1073, 2001.

ELLIS, C. E.; MURPHY, E. J.; MITCHELL, D. C.; GOLOVKO, M. Y.; SCAGLIA, F.; BARCELÓ-COBLIJN, G. C.; NUSSBAUM, R. L. Mitochondrial lipid abnormality and electron transport chain impairment in mice lacking alpha-synuclein. Mol. Cell Biol., v. 25, p. 10190-10201, 2005.

EPHRUSSI, B.; HOTTINGUER, H.; TAVLITSKI, J. Action de L'acriflavine sur les levures. II. Étude génétique du mutant "petite colonie". Ann. Inst. Pasteur, v. 76, p. 1-24, 1949.

EXNER, N.; LUTZ, A. K.; HAASS, C.; WINKLHOFER, K. F. Mitochondrial dysfunction in Parkinson's disease: molecular mechanisms and pathophysiological consequences. EMBO J., v. 31, n. 14, p. 3038-3062, 2012.

FANG, J.; BEATTIE, D. S. External alternative NADH dehydrogenase of Saccharomyces cerevisiae: a potential source of superoxide. Free Radic. Biol. Med., v. 34, p. 478-488, 2003.

FAURES-RENOT, M.; FAYE, G., MICHEL, F.; FUKUHARA, H. In vivo transcription of mitochondrial DNA in some ro-mutants. Biochemie, v. 56, n. 5, p. 681-91, 1974.

FELDMANN, H. Yeast: Molecular and Cell Biology. Weinheim: Wiley-VCH Verlag GmbH \& Co. KGaA, 2010. 334 p.

FENG, Z.; CHANG, Y.; CHENG, Y.; ZHANG, B. L.; QU, Z. W.; QIN, C.; ZHANG, J. T. Melatonin alleviates behavioral deficits associated with apoptosis and cholinergic system 
dysfunction in the APP 695 transgenic mouse model of Alzheimer's disease. J. Pineal Res., v. 37, p. 129-136, 2004.

FOURY, F.; KUCEJ, M. Yeast mitochondrial biogenesis: a model system for humans? Curr. Opin. Chem. Biol., v. 6, p. 106-111, 2001.

FOURY, F.; ROGANTI, T.; LECRENIER, N.; PURNELLE, B. The complete sequence of the mitochondrial genome of Saccharomyces cerevisiae. FEBS Lett., v. 440, p. 352-331, 1998.

GANGUlY, S.; MUMMANENI, P.; STEINBACH, P. J.; KLEIN, D. C.; COON, S.L. Characterization of the Saccharomyces cerevisiae homolog of the melatonin rhythm enzyme arylalkylamine $N$-acetyltransferase. J. Biol. Chem., v. 276, p. 47239-47247, 2001.

GEORGE, J. M.; JIN, H.; WOODS, W. S.; CLAYTON, D. F. Characterization of a novel protein regulated during the critical period for song learning in the zebra finch. Neuron, v. 15, n. 2, p. 361-372, 1995.

GERLACH, M.; DOUBLE, K. L.; BEN-SHACHAR, D.; ZECCA, L.; YOUDIM, M. B. H.; RIEDERER,P. Neuromelanin and its interaction with iron as a potential risk factor for dopaminergic neurodegeneration underlying Parkinson's disease. Neuroto. Res., v. 5, n. 1-2, p. 35-43, 2003.

GIASSON, B. I.; MURRAY, I. V.; TROJANOWSKI, J. Q.; LEE, V. M. A hydrophobic stretch of 12 amino acid residues in the middle of $\alpha$-synuclein is essential for filament assembly. J. Biol. Chem., v. 276, p. 2380-2386, 2001.

GIETZ, R. D., SUGINO, A. New yeast - Escherichia coli shuttle vectors constructed with in vitro mutagenized yeast genes lacking six-base pair restriction sites. Gene, v. 74, p. 527-534, 1998.

GOFFEAU, A.; BARRELL, B. G.; BUSSEY, H.; DAVIS, R. W.; DUJON, B.; FELDMANN, H.; GALIBERT, F.; HOHEISEL, J. D.; JACQ, C.; JOHNSTON, M.; LOUIS, E. J.; MEWES, H. W.; MURAKAMI, Y.; PHILIPPSEN, P.; TETTELIN, H.; OLIVER, S. G. Life with 6000 genes. Science, v. 274, n. 5287, p. 563-567, 1996.

GOLDSTEIN, S.; MEYERSTEIN, D.; CZAPSKI, G. The Fenton reagents. Free Radic. Biol. Med., v. 15, n. 4, p. 435-445, 1993.

GRANDIER-VAZEILLE, X.; BATHANY, K.; CHAIGNEPAIN, S.; CAMOUGRAND, N.; MANON, S.; SCHMITTER, J. M. Yeast mitochondrial dehydrogenases are associated in a supramolecular complex. Biochemistry, v. 40, p. 9758-9769, 2001.

HAAS, R. H.; NASIRIAN, F.; NAKANO, K.; WARD, D.; PAY, M.; HILL, R.; SHULTS, C. W. Low platelet mitochondrial complex I and complex II/III activity in early untreated Parkinson's disease. Ann. Neurol., v. 37, p. 714-722, 1995.

HANAHAN, D. Studies on transformation of Escherichia coli with plasmids. J. Mol. Biol., v. 166, p. 557-560, 1983. 
HANSEN， C.; BJÖRKLUND， T.; PETIT， G. H.; LUNDBLAD， M.; MURMU， R. P.; BRUNDIN, P.; LI, J. Y. A novel $\alpha$-synuclein-GFP mouse model displays progressive motor impairment, olfactory dysfunction and accumulation of $\alpha$-synuclein-GFP. Neurobiol. Dis., v. S0969-9961, n. 13, p. 131-139, 2013.

HARDELAND, R. Antioxidative protection by melatonin - Multiplicity of mechanisms from radical detoxification to radical avoidance. Endocrine, v. 27, p. 119-130. 2005.

HERRERO, E.; ROS, J.; BELLÍ, G.; CABISCOL, E. Redox control and oxidative stress in yeast cells. Biochim. Biophys. Acta, v. 1780, p. 1217-1235, 2008.

HILL, J. E.; MYERS, A. M.; KOERNER, T. J.; TZAGOLOFF, A. Yeast/E. coli shuttle vectors with multiple unique restriction sites. Yeast, v. 2, p. 163-167, 1986.

HODGES, P. E.; MCKEE, A. H. Z.; DAVIS, B. P.; PASYNE, W. E. B.; GARRELS, J. L. Yeast Protein Database (YPD): a model for the organization and presentation of genome-wide function data. Nucleic Acids Res., v. 27, p. 69-73, 1999.

HOLM, C.; MEEKS-WAGNER, D. W.; FANGMAN, W. L.; BOTSTEIN, D. A rapid, efficient method for isolating DNA from yeast. Gene, v. 42, p. 169-173, 1986.

HUANG, Y.; CHEUNG, L.; ROWE, D.; HALLIDAY, G. Genetic contributions to Parkinson's disease. Brain Res. Brain Res. Rev., v. 46, p. 44-70, 2004.

HUETHER, G.; POEGGELER, B.; REIMER, A.; GEORGE, A. Effect of tryptophan administration on circulating melatonin levels in chicks and rats: evidence for stimulation of melatonin synthesis and release in the gastrointestinal tract. Life Sci., v. 51, p. 945-953, 1992.

HWANG, O. Role of oxidative stress in Parkinson's disease. Exp. Neurobiol., v. 22, n. 1, p. 11-17, 2013.

IMLAY, J. A. Pathways of oxidative damage Annu. Rev. Microbiol., v. 57, p. 395-418, 2003.

ITOH, M. T.; ISHIZUKA, B.; KURIBAYASHI, Y.; AMEMYIA, A.; SUMI, Y. Melatonin, its precursors, and synthesizing enzyme activities in the human ovary. Mol. Hum. Reprod., v. 5, p. 402-408, 1999.

IUVONE, P. M.; BESHARSE, J. C. Regulation of indoleamine N-acetyltransferase activity in the retina: effects of light and dark, protein synthesis inhibitors and cyclic nucleotide analogs. Brain Res., v. 273, p. 111-119, 1983.

JAHN. R.; SÜDHOF, T. C. Synaptic vesicle traffic: rush hour in the nerve terminal. J. Neurochem., v. 61, p. 12-21, 1993.

JAKES, R.; SPILLANTINI, M. G.; GOEDERT, M. Identification of two distinct synucleins from human brain. FEBS Lett., v. 345, p. 27-32, 1994.

JANKOVIC, J. Parkinson's disease: clinical features and diagnosis. J. Neurol. Neurosurg. Psychiatry, v. 79, n. 4, p. 368-76, 2008. 
JIN, B. K.; SHIN, D. Y.; JEONG, M. Y.; GWAG, M. R.; BAIK, H. W.; YOON, K. S.; CHO, Y. H.; JOO, W. S.; KIM, Y. S.; BAIK, H. H. Melatonin protects nigral dopaminergic neurons from 1-methyl-4-phenylpyridinium (MPP+) neurotoxicity in rats. Neurosci. Lett., v. 245, p. 61-64, 1998.

JOSELIN, A. P.;HEWITT, S. J.; CALLAGHAN, S. M.; KIM, R. H.; CHUNG,Y. H.; MAK, T. W.; SHEN, J.; SLACK, R. S.; PARK, D. S. ROS- dependent regulation of Parkin and DJ-1 localization during oxidative stress in neurons. Hum. Mol. Genet., v. 21, p. 4888-4903, 2012.

JUNG, K. S.; SUNG, J. Y.; UM, J. W.; HATTORI, N.; MIZUNO, Y.; TANAKA, K.; PAIK, S. R.; KIM, J.; CHUNG, K. C. Parkin cleaves intracellular alpha-synuclein inclusions via the activation of calpain. J. Biol. Chem., v. 278, n. 43, p. 41890-41899, 2003.

JUNN, E.; MOURADIAN, M. M. Human alpha-synuclein over-expression increases intracellular reactive oxygen species levels and susceptibility to dopamine. Neurosci. Lett., v. 320, p. 146-150, 2002.

KAMP F.; EXNER, N.; LUTZ, A.K.; WENDER, N.; HEGERMANN, J.; BRUNNER, B.; NUSCHER, B.; BARTELS, T.; GIESE, A.; BEYER, K.; EIMER, S.; WINKLHOFER, K. F.; HAASS, C. Inhibition of mitochondrial fusion by alpha-synuclein is rescued by PINK1, Parkin and DJ-1. EMBO J., v. 29, n. 20, p. 3571-3589, 2010.

KHURANA, V.; LINDQUIST, S. Modelling neurodegeneration in Saccharomyces cerevisiae: why cook with baker's yeast? Nat. Rev. Neurosci., v. 11, p. 436-449, 2010.

KIM, S. W.; JANG, Y. J.; CHANG, J. W.; HYANG, O. Degeneration of the nigrostriatal pathway and induction of motor deficit by tetrahydrobiopterin: an in vivo model relevant to Parkinson's disease. Neurobiol. Dis., v. 13, p. 167-176, 2003.

KOCH, B. C. P.; NAGTEGAAL, E.; KERKHOF, G. A.; TER WEE, P. M. Circadian sleepwake rhythm disturbances in end-stage renal disease. Nat. Rev. Nephrol., v. 5, p. 407-416, 2009.

KOTLER, M.; RODRÍGUEZ, C.; SAINZ, R. M.; ANTOLÍN, I.; MENÉNDEZ-PELÁEZ, A. Melatonin increases gene expression for antioxidant enzymes in rat brain cortex. J. Pineal Res., v. 24, n. 2, p. 83-89, 1998.

KOWALTOWSKI, A. J.; SOUZA-PINTO, N. C.; CASTILHO, R. F.; VERCESI, A. E. Mitochondria and reactive oxygen species. Free Radic. Biol. Med., v. 47, p. 333-343, 2009.

KRUFT, V.; EUBEL, H.; JÄNSCH, L.; WERHAHN, W.; BRAUN, H. P. Proteomic approach to identify novel mitochondrial proteins in Arabidopsis. Plant Physiol., v. 127, p. 1694-1710, 2001.

KRUGER, R.; KUHN, W.; MULLER T.; WOITALLA, D.; GRAEBER, M.; KÖSEL, S.; PRZUNTEK, H.; EPPLEN, J. T.; SCHOOLS, L.; RIESS, O. Ala30Pro mutation in the gene encoding $\alpha$-synuclein in Parkinson's disease. Nat. Genet., v. 18, n. 2, p. 106-108, 1998. 
KVETNOY, I. M. Extrapineal melatonin: location and role within diffuse neuroendocrine system. Histochem. J., v. 31, p. 1-12, 1999.

LANGSTON, J. W.; BALLARD, P.; TETRUD, J. W.; IRWIN, I. Chronic parkinsonism in humans due to a product of meperidine-analog synthesis. Science, v. 219, n. 4587, p. 979-80, 1983.

LA VOIE, M. J.; OSTASZEWSKI, B. L.; WEIHOFEN, A.; SCHLOSSMACHER, M. G.; SELKOE, D. J. Dopamine covalently modifies and functionally inactivates parkin. Nat. Med., v. 11, n. 11, p. 1214-1221, 2005.

LENAZ, G.; FATO, R.; FORMIGGINI, G.; GENOVA, M.L. The role of coenzyme Q in mitochondrial electron transport. Mitochondrion, v. 7, S 8-33, 2007.

LI, W. W.; YANG, R.; GUO, J. C.; REN, H. M.; ZHA, X. L.; CHENG, J. S.; CAI, D. F. Localization of $\alpha$-Synuclein to mitochondria within midbrain of mice. Neuroreport, $v .18, \mathrm{n}$. 15, p. 1543-1546, 2007.

LILL, R.; MÜHLENHOFF, U. Iron-sulfur protein biogenesis in eukaryotes: components and mechanisms. Annu. Rev. Cell Dev. Biol., v. 22, p. 457-486, 2006.

LIMA, M. M. S.; ANDERSEN, M. L.; REKSIDLER, A. B.; VITAL, M. A. B. F.; TUFIK, $\mathrm{S}$. The role of the substantia nigra pars compacta in regulating sleep patterns in rats. PLoS ONE, v. 2, n. 6, e 513, 2007.

LIMONGI, J. C. P. Conhecendo melhor a doença de Parkinson: uma abordagem multidisciplinar com orientações práticas para o dia-a-dia. São Paulo: Plexus, 2001. 168 p.

LOWRY, O. H.; ROSEBROUGH, N. J.; FARR, A. L.; RANDALL, R. J. Protein measurement with the Folin phenol reagent. J. Biol. Chem., v. 193, p. 265-275, 1951.

LUTTIK, M. A. H.; OVERKAMP, K. M.; KÖTTER, P.; DE VRIES, S.; VAN DIJKEN, J. P.; PRONK, J. T. The Saccharomyces cerevisiae NDE1 e NDE2 genes encode separate mitochondrial NADH dehydrogenases catalyzing the oxidation of citosolic NADH. J. Biol. Chem., v. 273, p. 24529-24534, 1998.

MAHOWALD, M. W.; SCHENCK, C. H.; BORNEMANN, M. A. Pathophysiologic mechanisms in REM sleep behavior disorder. Curr. Neurol. Neurosci. Rep., v. 7, p. 167$172,2007$.

MARCZYNSKI, T. J.; YAMAGUCHI, N.; LING, G. M.; GRODZINSKA, L. Sleep induced by the administration of melatonin (5-methoxyn- acetyltryptamine) to the hypothalamus in unrestrained cats. Experientia, v. 20, p. 435-437, 1964.

MARGULIS, L. Origin of eukaryotic cells. New Haven, CT: Yale University Press, 1970. $371 \mathrm{p}$.

MARKUS, R. P.; BARBOSA JR, E. J. M.; FERREIRA, Z. F. Ritmos biológicos: entendendo as horas, os dias e as estações do ano. Einstein, v. 1, p. 143-148, 2003. 
MAROTEAUX, L.; CAMPANELLI, J. T.; SCHELLER, R. H. Synuclein: a neuron-specific protein localized to the nucleus and presynaptic nerve terminal. J. Neurosci., v. 8, p. 2804$2815,1988$.

MARRES, C. A. M.; DE VRIES, S.; GRIVEL, L. A. Isolation and inactivation of the nuclear gene encoding the rotenone-insensitive internal NADH: ubiquinone oxidoreductase of mitochondria from Saccharomyces cerevisiae. Eur. J. Biochem., v. 195, p. 857-862, 1991.

MARTIN, L. J.; PAN, Y.; PRICE, A. C.; STERLING, W.; COPELAND, N. G.; JENKINS, N. A.; PRICE, D. L.; LEE, M. K. Parkinson's disease alpha-synuclein transgenic mice develop neuronal mitochondrial degeneration and cell death. J. Neurosci., v. 26, n. 1, p. 4150, 2006.

MARTIN, M.; MACIAS, M.; ESCAMES, G.; REITER, R. J.; AGAPITO, M. T.; ORTIZ, G. G.; ACUÑA-CASTROVIEJO, D. Melatonin-induced increased activity of the respiratory chain complexes I and IV can prevent Mitochondrial damage induced by ruthenium red in vivo. J. Pineal Res., v. 28, p. 242-248, 2000.

MARTIN, M.; MACIAS, M.; LEON, J.; ESCAMES, G.; KHALDY, H.; ACUÑACASTROVIEJO, D. Melatonin increases the activity of the oxidative phosphorylation enzymes and the production of ATP in rat brain and liver mitochondria. Int. J. Biochem. Cell Biol., v. 34, p. 348-357, 2002.

MARTINAT, C.; SHENDELMAN, S.; JONASON, A.; LEETE, T.; BEAL, M. F.; YANG, L.; FLOSS, T.; ABELIOVICH, A. Sensitivity to oxidative stress in DJ-1- deficient dopamine neurons: an ES-derived cell model of primary Parkinsonism. PLoS Biol., v. 2, n. 11, e 327, 2004.

MATELL, M. S.; MECK, W. H. Neuropsychological mechanisms of interval timing behavior. Bio Essays, v. 22, n. 1, p. 94-103, 2000.

MATES, J. M. Effects of antioxidant enzymes in the molecular control of reactive species toxicology. Toxicology, v. 153, p. 150-158, 2000.

MATSUBARA, E.; BRYANT-THOMAS, T.; PACHECO QUINTO, J.; HENRY, T. L.; POEGGELER, B.; HERBERT, D.; CRUZ-SANCHEZ, F.; CHYAN, Y.J.; SMITH, M. A.; PERRY, G.; SHOJI, M.; ABE, K.; LEONE, A.; GRUNDKE-IKBAL, I.; WILSON, G. L.; GHISO, J.; WILLIAMS, C.; REFOLO, L. M.; PAPPOLLA, M. A.; CHAIN, D. G.; NERIA, E. Melatonin increases survival and inhibits oxidative and amyloid pathology in a transgenic model of Alzheimer's disease. J. Neurochem., v. 85, p. 1101-1108, 2003.

MAYO, J. C.; SAINZ, R. M.; ANTOLÍN, I.; HERRERA, F.; MARTIN, V.; RODRIGUEZ, C. Melatonin regulation of antioxidant enzyme gene expression. Cell Mol. Life Sci., v. 59, n. 10, p. 1706-1713, 2002.

MAYO, J. C.; SAINZ, R. M.; TAN, D. X.; ANTOLÍN, I.; RODRÍGUEZ, C.; REITER, R. J. Melatonin and Parkinson's disease. Endocrine, v. 27, p. 169-178, 2005.

MENÉNDEZ-PELÁEZ, A.; HOWES, K. A.; GONZÁLEZ-BRITO, A.; REITER, R. J. Nacetyltransferase activity, hydroxyindole-Omethyltransferase activity, and melatonin levels in 
the Harderian glands of the female Syrian hamster: changes during the light:dark cycle and the effect of 6-parachlorophenylalanine administration. Biochem. Biophys. Res. Commun., v. 145, p. 1231-1238, 1987.

MILLER, J. W.; SELHUB, J.; JOSEPH, J. A. Oxidative damage caused by free radicals produced during catecholamine autoxidation: protective effects of O-methylation and melatonin. Free Radic. Biol. Med., v. 21, p. 241-249, 1996.

MITCHELL, D. A.; MARSHALL, T. K.; DESCHENES, R. J. Vectors for the inducible overexpression of glutathione S-transferase fusion proteins in yeast. Yeast, v. 9, p. 715-722, 1993.

MONOULOU, J. C.; JOKOB, H.; SLONIMSKI, P. P. Mitochondrial DNA from yeast "petite" mutants: specific changes of buoyant density corresponding to different cytoplasmic mutations. Biochem. Biophys. Res. Commun., v. 24, p. 218-224, 1966.

MOLINOFF, P. B.; AXELROD, J. Biochemistry of catecholamines. Annu. Rev. Biochem, v. 40, p. 465-500, 1971.

MURPHY, M. P. How mitochondria produce oxygen species. Biochem. J., v. 417, p. 1-13, 2009.

NAKAMURA, K.; NEMANI, V. M.; AZARBAL, F.; SKIBINSKI, G.; LEVY, J. M.; EGAMI, K.; MUNISHKINA, L.; ZHANG, J.; GARDNER, B.; WAKABAYASHI, J.; SESAKI, H.; CHENG, Y.; FINKBEINER, S.; NUSSBAUM, R. L.; MASLIAH, E.; EDWARDS, R. H. Direct membrane association drives mitochondrial fission by the Parkinson disease-associated protein alpha-synuclein. J. Biol. Chem., v. 286, p. 2071020726, 2011.

NAGASHIMA, K.; KASAI, M.; NAGATA, S.; KAZIRO, Y. Structure of the two genes for the polypeptide chain elongation factor $1 \alpha(\mathrm{EF}-1 \alpha)$ form Saccharomyces cerevisiae. Gene, v. 45, p. 265-273, 1986.

NARENDRA, D. P.; TANAKA, A.; SUEN, D. F.; YOULE, R. J. Parkin is recruited selectively to impaired mitochondria and promotes their autophagy. J. Cell Biol., v. 183, p. 795-803, 2008.

NARENDRA, D. P.; JIN,S. M.; TANAKA, A.; SUEN, D.F.; GAUTIER, C. A.; SHEN,J.; COOKSON, M. R.; YOULE, R. J. PINK1 is selectively stabilized on impaired mitochondria to activate Parkin. PLoS Biol., v. 8, e 1000298, 2010.

NAUTA, H. J.; COLE, M. Efferent projections of the subthalamic nucleus: an autoradiographic study in monkey and cat. J. Comp. Neurol, v. 180, p. 1-16, 1978.

NEMANI, V. M.; LU, W.; BERGE, V.; NAKAMURA, K.; ONOA, B.; LEE, M. K.; CHAUDHRY, F. A.; NICOLL, R. A.; EDWARDS, R. H. Increased expression of alphasynuclein reduces neurotransmitter release by inhibiting synaptic vesicle reclustering after endocytosis. Neuron, v. 65, p. 66-79, 2010. 
NORRIS, E. H.; GIASSON, B. I.; LEE, V. M. Y. alpha-Synuclein: normal function and role in neurodegenerative diseases. Curr. Top. Dev. Biol., v. 60, p. 17-54, 2004.

OKATANI, Y.; WAKATSUKI, A.; REITER, R. J. Melatonin protects hepatic mitochondrial respiratory chain activity in senescence-accelerated mice. J. Pineal Res., v. 32, p. 143-148, 2002.

OUTEIRO, T. F.; LINDQUIST, S. Yeast cells provide insight into alpha-synuclein biology and pathobiology. Science, v. 302, p. 1772-1775, 2003.

PAHL, H. L. BAEUERLE, P. A. Oxygen and the control of gene expression. Bioessays, v. 16, p. 497-502, 1994.

PARIHAR, M. S.; PARIHAR, A.; FUJITA, M.; HASHIMOTO, M.; GHAFOURIFAR, P. Mitochondrial association of alpha-synuclein causes oxidative stress. Cell Mol. Life Sci., v. 65, p. 1272-1284, 2008.

PARKINSON, J. (1817) An essay on the shaking palsy. J. Neuropsychiatry Clin. Neurosci., v. 14, p. 223-236, 2002.

PERREAU-LENZ, S.; KALSBEEK, A.; GARIDOU, M. L.; WORTEL, J.; VAN DER VLIET, J.; VAN HEIJNINGEN, C.; SIMONNEAUX, V.; PÉVET, P.; BUIJS, R. M. Suprachiasmatic control of melatonin synthesis in rats: inhibitory and stimulatory mechanisms. Eur. J. Neurosci., v. 17, p. 221-228, 2003.

PIERCE, B. D.; WENDLAND, B. Sequence of the yeast protein expression plasmid pEG(KT). Yeast, v. 26, p. 349-353, 2009.

PIOLI, E. Y.; MEISSNER, W.; SOHR, R.; GROSS, C. E.; BEZARD, E.; BIOULAC, B. H. Differential behavioral effects of partial bilateral lesions of ventral tegmental area or substância negra pars compacta in rats. Neuroscience, v. 153, p. 1213-1224, 2008.

POEGGELER, B.; MIRAVALLE, L.; ZAGORSKI, M. G.; WISNIEWSKI, T.; CHYAN, Y. J.; ZHANG, Y.; SHAO, H.; BRYANT-THOMAS, T.; VIDAL, R.; FRANGIONE, B.; GHISO, J.; PAPPOLLA, M. A. Melatonin reverses the profibrillogenic activity of apolipoprotein E4 on the Alzheimer amyloid A $\beta$ peptide. Biochemistry, v. 40, p. 1499515001, 2001.

POLYMEROPOULOS, M. H.; LAVEDAN， C.; LEROY， E.; IDE， S. E.; DEHEJIA, A.; DUTRA, A.; PIKE, B.; ROOT, H.; RUBENSTEIN, J.; BOYER, R.; STENROOS, E. S.; CHANDRASEKHARAPPA, S.; ATHANASSIADOU, A.; PAPAPETROPOULOS, T.; JOHNSON, W. G.; LAZZARINI, A. M.; DUVOISIN, R. C.; DI IORIO, G.; GOLBE, L. I.; NUSSBAUM, R. L. Mutation in the alpha-synuclein gene identified in families with Parkinson's disease. Science, v. 279, p. 2045-2047, 1997.

PRANKE, I. M.; MORELLO, V.; BIGAY, J.; GIBSON, K.; VERBAVATZ, J. M.; ANTONNY, B.; JACKSON, C. L. $\alpha$-Synuclein and ALPS motifs are membrane curvature sensors whose contrasting chemistry mediates selective vesicle binding. J. Cell Biol., v. 194, p. 89-103, 2011. 
QUINN, J.; KULHANEK, D.; NOWLIN, J.; JONES, R.; PRATICO, D.; ROKACH, J.; STACKMAN, R. Chronic melatonin therapy fails to alter amyloid burden or oxidative damage in old Tg2576 mice: implications for clinical trials. Brain Res., v. 1037, p. 209-213, 2005 .

RABILlOUD, T.; HELlER, M.; RIGOBELlO, M. P.; BINDOLI, A.; AEBERSOLD, R.; LUNARDI, J. Two-dimensional electrophoresis of human placental mitochondria and protein identification by mass spectrometry: toward a human mitochondrial proteome. Electrophoresis, v. 19, p. 1006-1014, 1998.

REITER, R. J. Oxidative damage in the central nervous system: protection by melatonin. Prog. Neurobiol., v. 56, p. 359-384, 1998.

REITER, R. J.; TAN, D. X.; LEON, J.; KILIC, U.; KILIC, E. When melatonin gets on your nerves: its beneficial actions in experimental models of stroke. Exp. Biol. Med, v. 230, p. 104-117, 2005.

REITER, R. J.; TAN, D. X.; MANCHESTER, L. C.; LOPES-BURILLO, S.; SAINZ, R. M.; MATO, J. C. Melatonin: detoxification of oxygen and nitrogen-based toxic reagents. Adv. Exp. Med. Biol.,v. 527, p. 539-548, 2003.

RODRIGUEZ, C.; MAYO, J. C.; SAINZ, R. M.; ANTOLÍN, I.; HERRERA, F.; MARTÍN, V.; REITER, R. J. Regulation of antioxidant enzymes: a significant role for melatonin. J. Pineal Res., v. 36, p. 1-9, 2004.

ROSE, M. D.; WINSTON, F.; HIETER, P. Methods of Yeast Genetics. Cold Spring Harbor Laboratory. New York: Cold Spring Harbor Press; 1990. 198 p.

ROSPIGLIOSI, C. C.; MCCLENDON, S.; SCHMID, A. W.; RAMLALL, T. F.; BARRÉ, P.; LASHUEL, H. A.; ELIEZER, D. E46K Parkinson's-linked mutation enhances C-terminal-toN-terminal contacts in $\alpha$-synuclein. J. Mol. Biol,. v. 388, p. 1022-1032, 2009.

SACK, R. L.; LEWY, A. J.; ERB, D. L.; VOLLMER, W. M.; SINGER, C. M. Human melatonin production decreases with age. J. Pineal Res., v. 3, p. 379-388, 1986.

SAMBROOK, J.; FRITSCH, E. F.; MANIATIS, T. Molecular cloning: a laboratory manual. Cold Spring Harbor Laboratory, New York: Cold Spring Harbor Press, 1989. 1629 p.

SANDYK, R. Pineal melatonin functions: possible relevance to Parkinson's disease. Int. J. Neurosci., v. 50, p. 37-53, 1990.

SARASTE, M. Oxidative phosphorylation at the fin de sciècle. Science, v. 283, p. 1488-1492, 1999.

SCHAFFER, S. W.; SULEIMAN, M. S. Mitochondria: the dynamic organelle. New York: Springer, 2007. $359 \mathrm{p}$.

SCHENCK, C. H.; MAHOWALD, M. W. REM sleep behavior disorder: clinical, developmental, and neuroscience perspectives 16 years after its formal identification in sleep. Sleep, v. 25, p. 120-138, 2002. 
SCHIESTL, R. H.; GIETZ, R. D. High efficiency transformation of intact yeast cells using single stranded nucleic acids as a carrier. Current Genetics, v. 16, p. 339-346, 1989.

SCHIRMAIER, F.; PHILIPPSEN, P. Identification of two genes coding for the translation elongation factor EF-1 alpha of S. cerevisiae. EMBO J., v. 3, p. 3311-3315, 1984.

SCHMID, H. A. Decreased melatonin biosynthesis, calcium flux, pineal gland calcification and aging: a hypothetical framework. Gerontology, v. 39, p. 189-199, 1993.

SCHULTZ, W. Multiple dopamine functions at different time courses. Annu. Rev. Neurosci., v. 30, p. 259-288, 2007.

SEGURA-AGUILAR J.; LIND, C. On the mechanism of the Mn3+-induced neurotoxicity of dopamine: prevention of quinone-derived oxygen toxicity by DT diaphorase and superoxide dismutase. Chemico-Biological Interactions, v. 72, p. 309-324, 1989.

SEKIGAWA, A.; TAKAMATSU, Y.; SEKIYAMA, K.; TAKENOUCHI, T.; SUGAMA, S.; WARAGAI, M.; FUJITA, M.; HASHIMOTO, M. Diversity of mitochondrial pathology in mouse model of axonal degeneration in synucleinopathies. Oxid. Med. Cell Longev., v. 2013, ID: 817807, 2013. 6 p.

SERE, Y. Y.; REGNACQ, M.; COLAS, J.; BERGES, T. A Saccharomyces cerevisiae strain unable to store neutral lipids is tolerant to oxidative stress induced by $\alpha$-synuclein. Free Radic. Biol. Med., v. 49, p. 1755-1764, 2010.

SHERER, T. B.; KIM, J. H.; BETARBET, R.; GREENAMYRE, J. T. Subcutaneous rotenone exposure causes highly selective dopaminergic degeneration and $\alpha$-synuclein aggregation. Exp. Neurol., v. 179, p. 9-16, 2003.

SHERER, T. B.; BETARBET, R.; TESTA, C. M.; SEO, B. B.; RICHARDSON, J. R.; KIM, J. H.; MILlER, G. W.; YAGI, T.; MATSUNO-YAGI, A.; GREENAMYRE, J. T. Mechanism of Toxicity in Rotenone Models of Parkinson's Disease. J. Neurosci., v. 23, p. 10756-10764, 2003.

SHIMURA, H.; HATTORI, N.; KUBO, S.; MIZUNO, Y.; ASAKAWA, S.; MINOSHIMA, S.; SHIMIZU, N.; IWAI, K.; CHIBA, T.; TANAKA, K.; SUZUKI, T. Familial Parkinson disease gene product, Parkin, is a ubiquitin-protein ligase. Nat. Genet., v. 25, p. 302-305, 2000 .

SINGLETON, A. B.; FARRER, M.; JOHNSON, J.; SINGLETON, A.; HAGUE, S.; KACHERGUS, J.; HULOIHAN, M.; PEURALINNA, T.; DUTRA, A.; NUSSBAUM, R.; LINCOLN, S.; CRAWLEY, A.; HANSON, M.; MARAGANORE, D.; ADLER, C.; COOKSON, M. R.; MUENTER, M.; BAPTISTA, N.; MILLER, D.; BLANCATO, J.; HARDY, J.; GWINN-HARDY, K. $\alpha$-Synuclein locus triplication causes Parkinson's disease. Science, v. 302, p. 841, 2003.

SMALL, W.; MCALLISTER-HENN, L. Identification of a cytosolically directed NADH dehydrogenase in mitochondria of Saccharomyces cerevisiae. J. Bacteriol., v. 180, p. 40514055, 1998. 
SOHAL, R. S.; MOCKETT, R. J.; ORR, W.C. Mechanisms of aging: an appraisal of the oxidative stress hypothesis. Free Radic. Biol. Med., v. 33, p. 575-586, 2002.

SOLANS, A.; ZAMBRANO, A.; RODRÍGUEZ, M.; BARRIENTOS, A. Cytotoxicity of a mutant huntingtin fragment in yeast involves early alterations in mitochondrial OXPHOS complexes II and III. Hum. Mol. Genet., v. 15, p. 3063-3081, 2006.

SPILLANTINI, M. G.; SCHMIDT, M. L.; LEE, V. M. Y.; TROJANOWSKI, J. Q.; JAKES, R.; GOEDERT, M. $\alpha$-synuclein in Lewy bodies. Nature, v. 388, p. 839-840, 1997.

SRINIVASAN, V.; PANDI-PERUMAL, S. R.; MAESTRONI, G. J. M.; ESQUIFINO, A. I.; HARDELAND, R.; CARDINALI, D. P. Role of melatonin in neurodegenerative diseases. Neurotox. Res., v. 7, p. 293-318, 2005.

SRINIVASAN, V.; PANDI-PERUMAL, S. R.; CARDINALI, D. P.; POEGGELER, B.; HARDELAND, R. Melatonin in Alzheimer's disease and other neurodegenerative disorders. Behav. Brain Funct., v. 2, art. 15, 2006.

STEFANINI, I.; DAPPORTO, L.; LEGRAS, J. L.; CALABRETTA, A.; DI PAOLA, M.; DE FILIPPO, C.; VIOLA, R.; CAPRETTI, P.; POLSINELLI, M.; TURILLAZZI, S.; CAVALIERI, D. Role of social wasps in Saccharomyces cerevisiae ecology and evolution. Proc. Natl. Acad. Sci., v. 109, p. 13398-13403, 2012.

SUN, J.; TRUMPOWER, L. Superoxide anion generation by the cytochrome bc1 complex. Arc. Biochem. Biophys., v. 419, p. 198-206, 2003.

TAIT, S. G.; GREEN, D. R. Mitochondria and cell death: outer membrane permeabilization and beyond. Nat. Mol. Cell Biol., v. 11, p. 621-632, 2010.

TAN, D. X.; CHEN, L. D.; POEGGELER, B.; MANCHESTER, L. C.; REITER, R. J. Melatonin: a potent, endogenous hydroxyl radical scavenger. Endocr. J., v. 1, p. 57-60, 1993.

TAN, D. X.; MANCHESTER, L. C.; REITER, R. J.; QI, W. B.; KARBOWNIK, M.; CALVO, J. R. Significance of Melatonin in Antioxidative Defense System: Reactions and Products. Neurosignals., v. 9, p. 137-159, 2000.

TANNER, C. M.; KAMEL, F.; ROSS, G. W.; HOPPIN, J. A.; GOLDMAN, S. M.; KORELL, M.; MARRAS, C.; BHUDHIKANOK, G. S.; KASTEN, M.; CHADE, A. R.; COMYNS, K.; RICHARDS,M. B.; MENG, C.; PRIESTLEY, B.; FERNANDEZ, H. H.; CAMBI, F.; UMBACH, D. M.; BLAIR, A.; SANDLER, D. P.; LANGSTON, J. W. Rotenone, Paraquat, and Parkinson's Disease. Environ. Health Perspect., v. 119, p. 866-872, 2011.

TRACHOOTHAM, D.; ALEXANDRE, J.; HUANG, P. Targeting cancer cells by ROSmediated mechanisms: a radical therapeutic approach? Nat. Rev. Drug Discov., v. 8, p. 579597, 2009.

TUMES, M.; PEDRAZA, R.; VALLADARES, L. Melatonin in the rat testis: evidence for local synthesis. Steroids, v. 61, p. 65-68, 1996. 
TURRENS, J. F. Mitochondrial formation of reactive oxygen species. J. Physiol., v. 552, p. 335-344, 2003.

TZAGOLOFF, A. Mitochondria. New York: Plenum Press, 1982. 342 p.

TZAGOLOFF, A.; AKAI, A.; NEEDLEMAN, R. B. Assembly of the mitochondrial membrane system. Characterization of nuclear mutants of Saccharomyces cerevisiae with defects in mitochondrial ATPase and respiratory enzymes. J. Biol. Chem., v. 250, p. 82288235, 1975.

VAN RAAMSDONK, J. M.; HEKIMI, S. Superoxide dismutase is dispensable for normal animal lifespan. Proc. Natl. Acad. Sci., v. 109, p. 5787-5790, 2012.

WALLACE, D. C. A mitochondrial paradigm of metabolic and degenerative diseases, aging and cancer: a dawn for evolutionary medicine. Annu. Rev. Genet., v. 39, p. 359-407, 2005.

WEINREB, P. H.; ZHEN, W.; POON, A. W.; CONWAY, K. A.; LANSBURY JR, P. T. NACP, a protein implicated in Alzheimer's disease and learning, is natively unfolded. Biochemistry, v. 35, p. 13709-13715, 1996.

WESTERMANN, B. Mitochondrial fusion and fission in cell life and death. Nat. Mol. Cell Biol., v. 11, p. 872-884, 2010.

XIE, W.; CHUNG, K. K. Alpha-synuclein impairs normal dynamics of mitochondria in cell and animal models of Parkinson's disease. J. Neurochem., v. 122, p. 404-414, 2012.

XU, J.; KAO, S. Y.; LEE, F. J. S.; SONG,W. H.; JIN, L. W.; YANKNER, B. A. Dopaminedependent neurotoxicity of alpha-synuclein: a mechanism for selective neurodegeneration in Parkinson disease. Nat. Med., v. 8, p. 600-606, 2002.

YALCIN, A.; KILINC, E.; KOCTURK, S.; RESMI, H.; SOZMEN, E. Y. Effect of melatonin cotreatment against kainic acid on coenzyme Q10, lipid peroxidation and Trx mRNA in rat hippocampus. Int. J. Neurosci., v. 114,p. 1085-1097, 2004.

YONETANI, M.; NONAKA, T.; MASUDA, M.; INUKAI, Y.; OIKAWA, T.; HISANAGA, S.; HASEGAWA, M. Conversion of wild-type $\alpha$-synuclein into mutant-type fibrils and its propagation in the presence of A30P mutant. J. Biol. Chem., v. 284, p. 7940-7950, 2009.

YOUNGSTEDT, S. D.; KRIPKE, D. F.; ELliOTT, J. A.; KLAUBER, M. R. Circadian abnormalities in older adults. J. Pineal Res., v. 31, p. 264-272, 2001.

YUAN, H.; PANG, S. F. $\left[{ }^{125} \mathrm{I}\right]$ Iodomelatonin-binding sites in the pigeon brain: binding characteristics, regional distribution and diurnal variation. J. Endocrinol., v. 128, p. 475-482, 1991.

ZARRANZ, J. J.; ALEGRE, J.; GOMEZ-ESTEBAN, J. C.; LEZCANO, E.; ROS, R.; AMPUERO, I.; VIDAL, L.; HOENICKA, J.; RODRIGUEZ, O.; ATARES, B.; LLORENS, V.; GOMEZ TORTOSA, E.; DEL SER, T.; MUÑOZ, D. G.; de YBENES, J. G. The new mutation, E46K, of $\alpha$-synuclein causes Parkinson and Lewy body dementia. Ann. Neurol., v. 55, p. 164-173, 2004. 
ZAMPOL, M. A.; BUSSO, C., GOMES, F., FERREIRA-JUNIOR, J. R., TZAGOLOFF, A., BARROS, M. H. Over-expression of COQ10 in Saccharomyces cerevisiae inhibits mitochondrial respiration. Biochem. Biophys. Res. Commun., v. 402, p. 82-87, 2010. 